\title{
فعالية برنامج مقترح باستخدام استراتيجية تعلم الأقران في تنمية الوعي المائي لاى أطفال الروضة
}

إعداد

أزهار البدري محمد عبد الكريم(")

إثراف

أ.د/ حنان محمد صفوت("**)

أ.د/ عاطف عدلي فهمي("*)

مستخلص البحث

هدف البحث الحالي إلى تتمية الوعي المائي لدي طفل الروضة من خلال استخدام

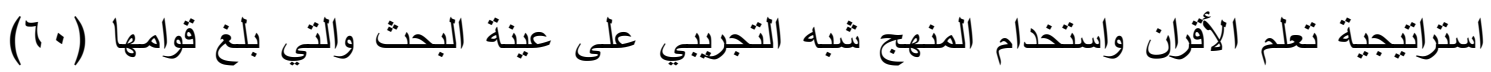

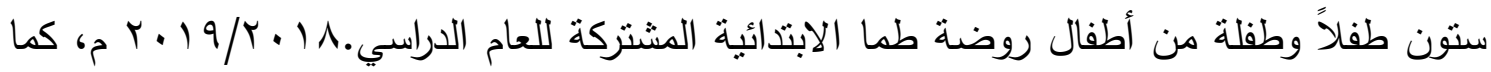
استخدم البحث مجموعة من الأدوات هي اختبار رسم الرجل (لجوادنف وهارديس)، البرنامج المقترح

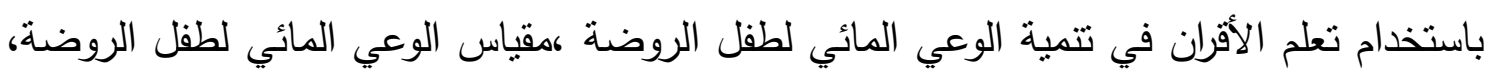
وقد جاءت نتائج البحث مشيرة إلى أن البرنامج المقترح باستخدام استراتيجية تعلم الأقران أثبت فعاليته في تتمية الوعي المائي لطفل الروضة. مما يؤكد على فعاليتها وايجابيتها لكونها استراتيجية من بن

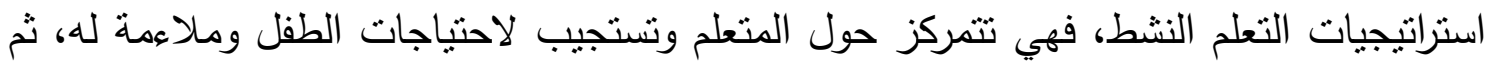
انتهي البحث إلى عدد من النوصيات ومنها تدريب معلمات قبل الخدمة على استخدام استراتيجية

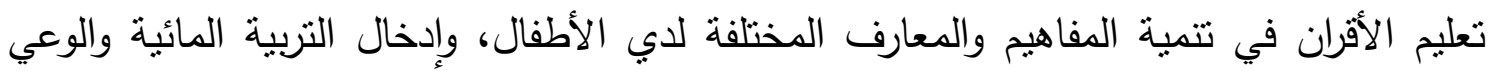
المائي في مناهج التعليم للمراحل التعليمية المختلفة،، وتضمين البعد الخاص بالتربية المائية والوعي المائي في المناهج الخاصة بإعداد المعلمين عامة ومعلمة رياض الأطفال خاصة.

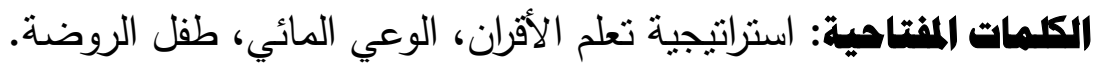

(") معلم رياض أطفال (عضو وحدة قياس الجودة) بإدارة طما التعليمية.

("**) أستاذ المناهج وطرق تربية الطفل وعميد كلية التربية للطفولة المبكرة - جامعة القاهرة.

(***) أستاذ المناهج وطرق تربية الطفل ورئيس قسم العلوم التربوية كلية التربية للطفولة المبكرة - جامعة المنيا. 
The effectiveness of a proposed program using peer learning strategy in developing water awareness among kindergarten children

By

Azhar Al-Badry Mohammed Abdul Karim (*)
Supervised by

Prof/ Dr. Atef Adly Fahmy (**)

Prof/Dr. Hanan Mohamed Safwat $(* * *)$

\section{Abstract:}

The current research aimed at developing water awareness among kindergarten children through using peer learning strategy. The researcher utilized the quasi-experimental research approach. The research sample consisted of (60) kindergarten children who enrolled at Tama Joint Primary school kindergarten for the academic year 2018/2019. For data collection, the researcher used: Man drawing test (for Guadin and Hardees), water awareness scale for kindergarten children (prepared by the researcher), and the proposed program using peer learning to develop kindergarten children water awareness. The research results indicated the effectiveness of the proposed program using peer learning strategy in developing some water awareness among kindergarten children. This confirms the effectiveness and positivism of this strategy as it is one of active learning strategies and a learner- centered one which responds to the child's needs and suits his characteristics. The research concluded with a number of recommendations, including: training pre-service teachers on the use of peer learning strategy in developing different concepts and knowledge among children, introducing water education and water concepts in the educational curricula for the various educational stages, and including the water education and awareness dimensions in the curricula of preparing teachers in general and kindergarten teachers in particular.

Keywords: peer learning strategy, water awareness, kindergarten child.

(*) Kindergarten Teacher and a Member of the Quality Measurement Unit at Tama Educational Administration

(**) Professor of Curricula and Methods of Child Education, and the Dean of College of Education for Early Childhood, Cairo University

(***)Professor of Curricula and Methods of Child Education, and the Head of Educational Sciences Department, College of Education for Early Childhood, Cairo University 
أولاًَ- الإطار العام للبحث:

مقدمة:

يواجه العالم اليوم الكثير من المشكلات المختلفة والتي يمكنها أن نشعل الحروب بين الدول، ومن بين نلك المشكلات مشكلة المياه التي تعتبر مواجهتها بمثابة التحدي الاستراتيجي والقومي للدول، حيث تعد المياه من أكثر الموارد الطبيعية تأثيراً على الأمن البشري بوصفها مورداً إنتاجياً وحاسما في استمرار الحياة.

وتبرز أهمية المياه من خلال الدور المهم والحيوي في عملية التتمية الاقتصادية والاجتماعية حيث تتجلي هذه الأهمية في قول الخالق عز وجل (وَجَعَلْنَا مِنْ الْمَاعِ كُلَّ شَيْعِ حَيِّ)

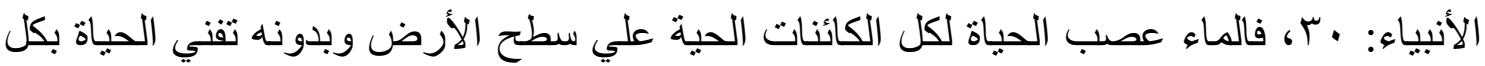
أثكالها ومظاهرها؛ فهو العنصر الأول المكون لكل خلية حية. (عباس محمد شراقي، 10 . ب، 0)،

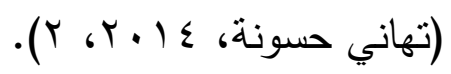

إن للسلوك البشري دور مؤثز في حدوث مشكلات نقص وتلوث المياه لذا ينبغي إجراء الترتيبات اللازمة من خلال مؤسسات المجتمع المختلفة ومنها المؤسسات التعليمية؛ فلا بد من إدراج التربية المائية المياه كجزء من الأنشطة التعليمية والمناهج الدراسية وذللك بتوجيه المعلمين بالاهتمام بالتربية المائية أثتاء عملية التخطيط واعداد الدروس والأنشطة، وربط موضوع المياه بجميع المواد الدراسية المختلفة (Bron, Jeroen. van Vliet, Eddie, 2013)؛ وأكدت علي ذلك دراسة (Cankaya, Cemile; Filik Iscen, Cansu, 2015) علي أن الوعي المائي للمعلمين مهم جداً، فهم يمثلون القدوة لطلابهم، إضافة لدورهم في تكوين السلوكيات السليمة لديهم. Courtney T. Owens ) وتطوير برامج تعليمية تركز على ممارسات مبتكرة للحفاظ على المياه (\& Alexa J. Lamm, 2017

كما أثنارت دراسة (P.W. Soo. Cheam, 2012) إلي أن تعليم المحافظة علي المياه يبدأ من المدرسة، كما أكدا علي أنه مع التوعية الايجابية يمكن المحافظة علي المياه وتوفيرها؛ فالإنسان من الكائنات الحية الوحيد القادر علي التحكم وتتظيم الموارد المائية وهذه القدرة تأتي من Coban, et ) الاحساس بالمسئولية في فهم وحماية المجاري المائية والأنهار، كما أكدت دراسة علي دور التربية المائية والمناهج الدراسية في زيادة المعرفة والوعي بأهمية المحافظة علي المياه، والمواقف السلوكيات الواجب اتباعها للمحافظة عليها. 
وقد أكدت العديد من الدراسات علي أهمية التربية المائية والوعي المائي والمفاهيم المائية

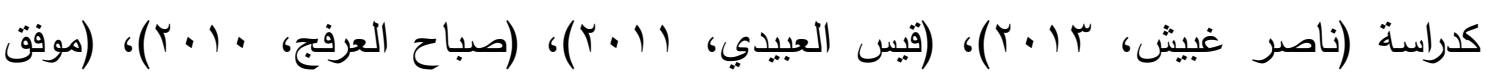

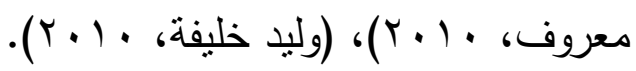

إن استراتيجية تعلم الأقران طريقة فعالة لزيادة الدافعية للتعلم؛ وتحول بيئة التعلم من بيئة

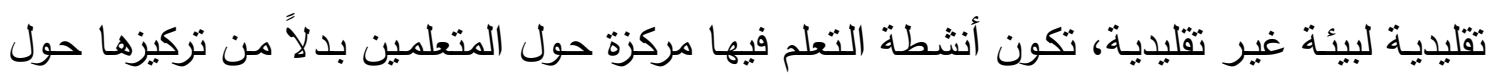

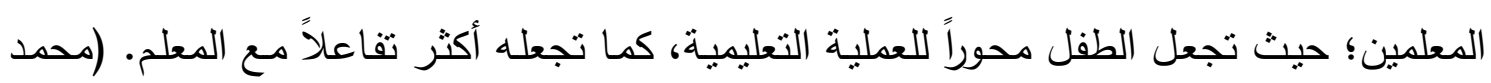

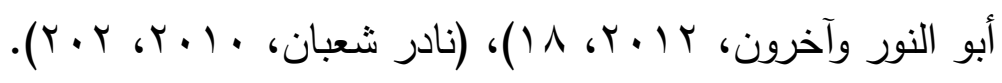

لذا تحاول الباحثة في هذا البحث استخدام استراتيجية تعلم الأقران في إعداد برنامج مقترح لتتمية بعض الوعي المائي لدى أطفال الروضة وذلك بما يتتاسب مع المرحلة العمرية لهؤلاء

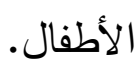

مشكلة البحث:

نظراً لأن مشكلات نقص الموارد المائية وتوقعات تفاقمها في المستقبل تفرض نفسها في

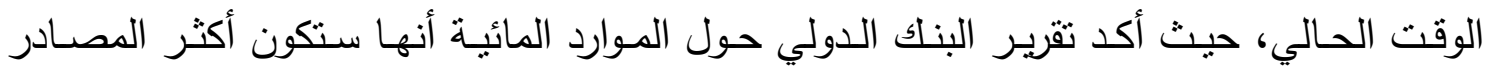

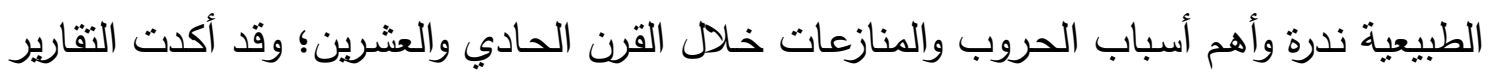

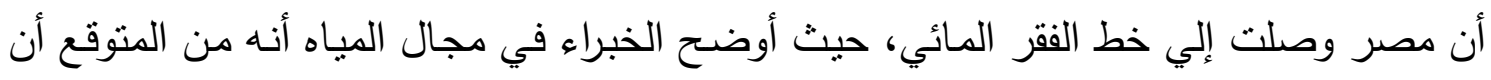

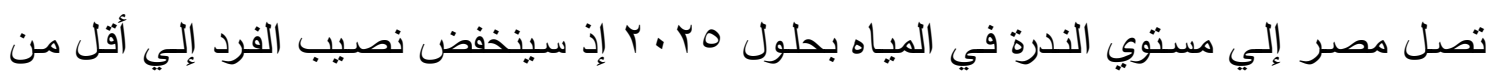

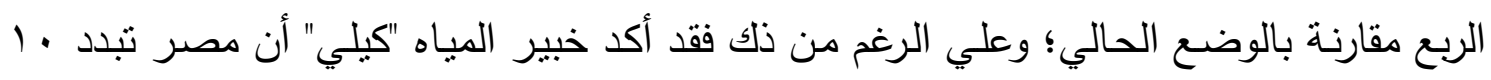

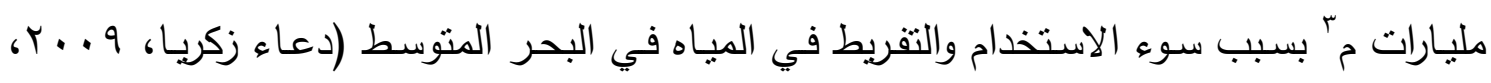

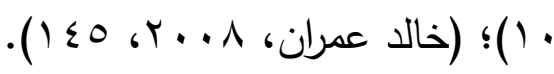
لذا يعد الاهتمام برفع مستوي الوعي لدي الأطفال بأهمية المياه والحفاظ عليها ضروري

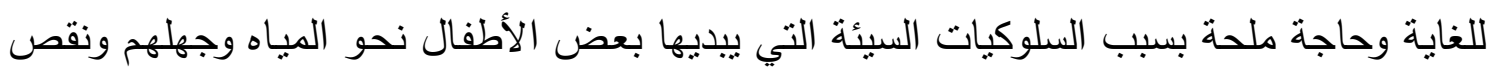

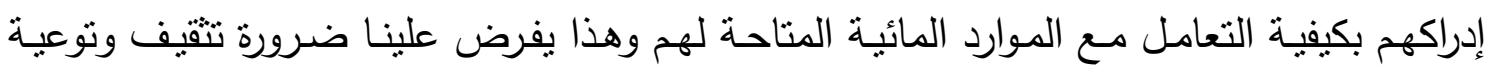

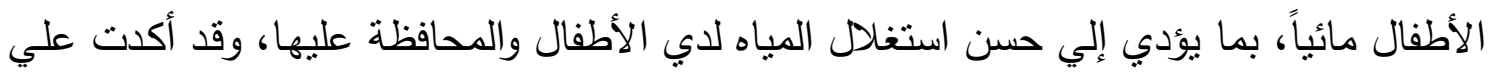

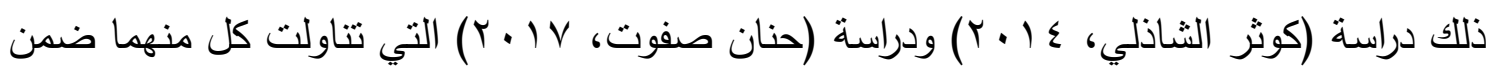
محاورها بعد ترشيد المياه لدي الأطفال، لذا بمكن القول بأن رفع مستوري الوعي المائي لدي الأطفال

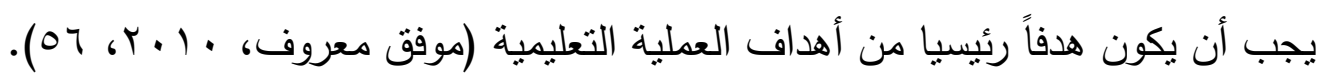


ويـري العديد مـن التربـويين ضـرورة أن تسـي الدنـاهج الدراسـية المختلفة نحـو تعديل الاحساس بقضايا ومشكلات المياه لدي الأطفال في المراحل الدراسية المختلفة وذلك من خلال عدة التهان محاور أساسية هي: المحسور المعرفي: وذلك باكتسـاب الأطفال الحقائق و المفـاهيم والتعميمـات المرتبطـة بالقضـايا والمشكلات المائية.

المحور الأدائي: وذلك بإكساب الأطفال مهارات التعامل الجيد مع المياه داخل وخارج المنازل. المحور الوجداني: وذلك بتتمية الوعي المائي والاتجاهات المرغوبة فيها تجاه المياه وتتمية القيم

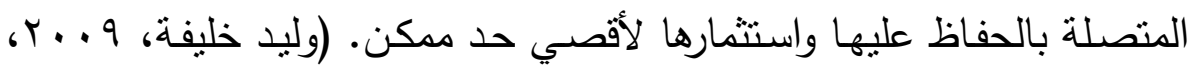

وقد أكدت نتائج العديد من الدراسات علي قصور وتدني الوعي بقضايا المياه المختلفة مثل

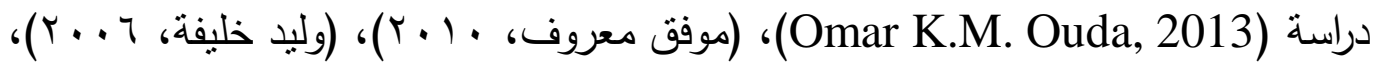
وعلي الرغم من أهمية المفاهيم المائية والوعي المائي وضرورة الاهتمام بتربية الأطفال وتربيتهم تربية مائية تركز علي انماء الوعي المائي لديهم للمساعدة في الحفاظ علي الحياة وحل

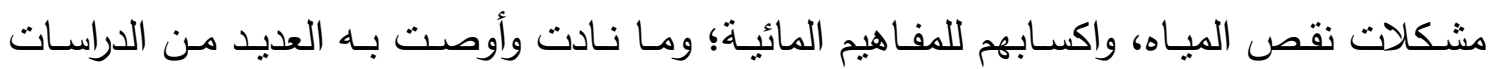
بضرورة إجراء دراسات وبحوث في تتمية الوعي المائي في المراحل الدراسية المختلفة ومنها دراسة

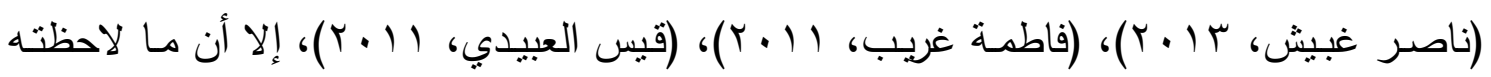
الباحثة من خلال عمها كمعلمة لرياض الأطفال وكذلك إنثرافها علي العديد من الروضات (كعضو

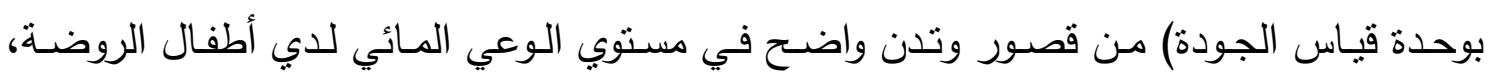
وقصور في تتاول المعلمات لقضايا المياه.

وتعد استراتيجية تعلم الأقران من الاستراتيجيات الهامة التي لها تأثنير إيجابي في عمليتي

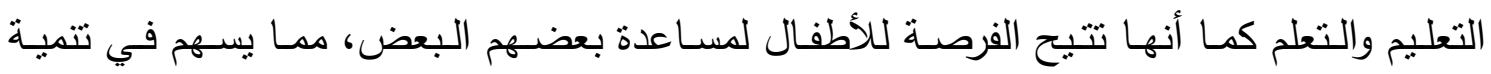

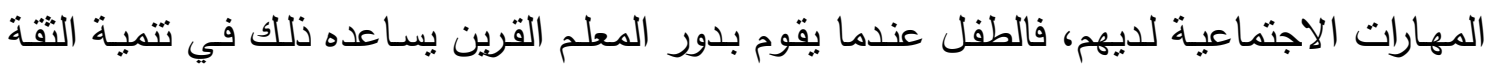
بالنفس والقدرة علي اتخاذ القرار وحل المشكلات وتحمل المسئولية، كما أنها تدعم القرين المتعلم

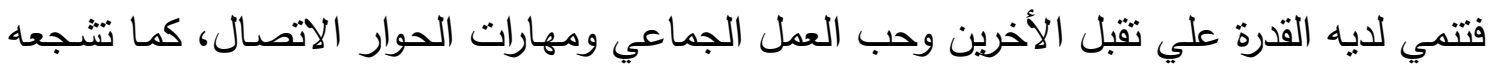

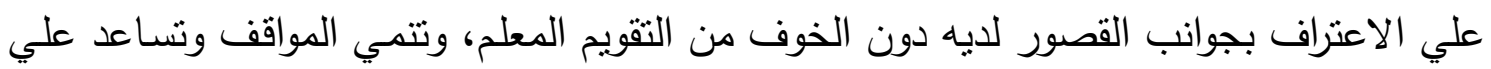

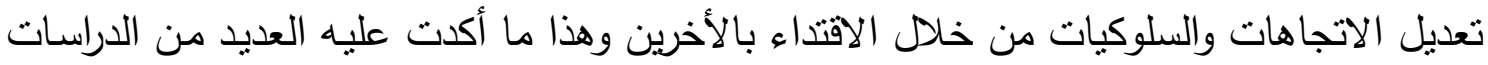

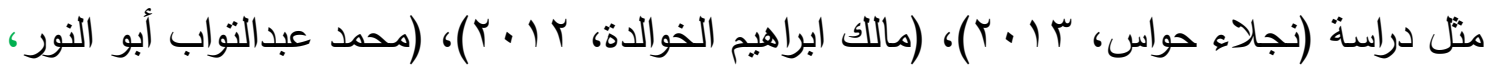

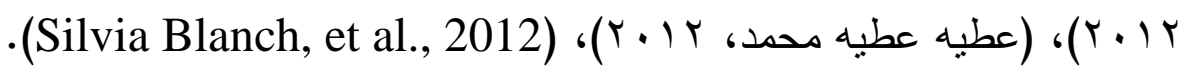


وعلى الرغم من ذلك إلا أنها لم تحظي بالاهتمام المناسب في رياض الأطفال كما أنـه بملاحظة الباحثة من خلال عملها وإنشرافها علي العديد من الروضات من ندرة استخدام استراتيجية

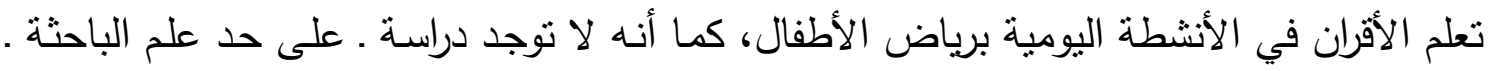

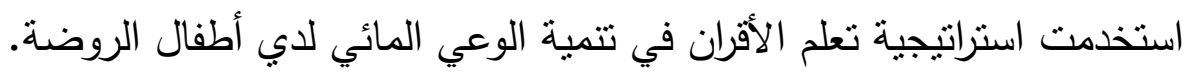

لذا فإن مشكلة البحث الحالي تتحدد في الإجابة علي التساؤل الرئيسي الآتي:

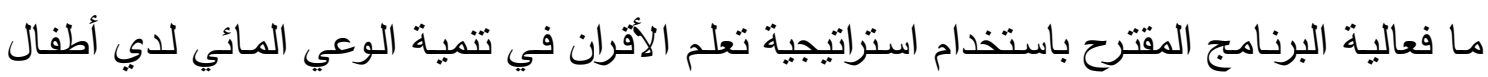

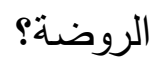

\section{ويتفرع من هذا السؤال الأسئلة الآتية: -}

ا ـ ما مكونات البرنامج المقترح لتتمية الوعي المائي باستخدام استراتيجية تعلم الأقران لطفل

$$
\text { الروضة ؟ مأبات }
$$

r. ما مدي فعالية البرنامج المقترح باستراتيجية تعلم الأقران في تتمية الوعي المائي لطفل

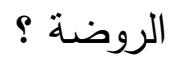

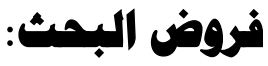

ا • يوجد فرق دال إحصائياً بين متوسطي درجات المجموعة التجريبية في التطبيقين القبلي

$$
\text { والبعدي علي مقياس الوعي المائي لصالح التطبيق البعدي دئي }
$$

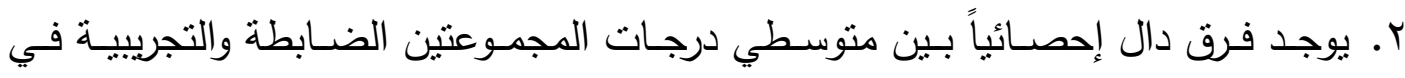

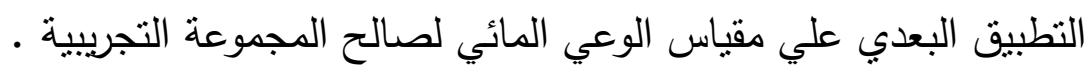

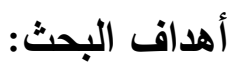

ا. إعداد برنامج مقترح باستخدام استراتيجية تعلم الأقران في تتمية الوعي المائي لدى أطفال

$$
\text { الروضة. }
$$

r. التعـرف على طبيعـة اسـتراتيجية تدريس الأقـران وأهيتهـا وكيفيـة نوظيفهـا في مرحــة

$$
\text { الروضة. }
$$

r. التعرف على فعالية البرنامج المقترح باستخدام استراتيجية تعلم الأقران في تتمية الوعي لدي

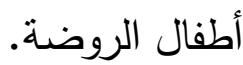

1. يستمد البحث الحالي أهيته من تتاوله لجانب على قدر كبير من الأهية في حياتتا ألا

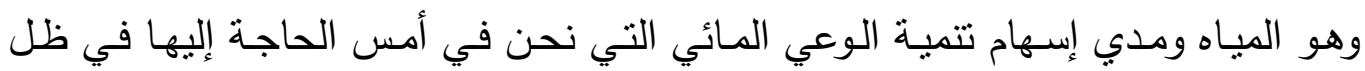


أزمات ومشكلات المياه سواء المحلية او الإقليمية أو العالميـة حيث أوصت الكثير من الدراسات والبحوث والمؤتمرات بأهمية تتمية الوعي المائي. r. بقدم إطار نظري عن الوعي المائي واستراتيجية تعلم الأقران.

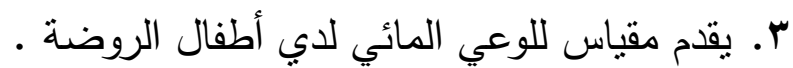
ـ. يسهم في تتمية الوعي المائي لدي أطفال الروضة.

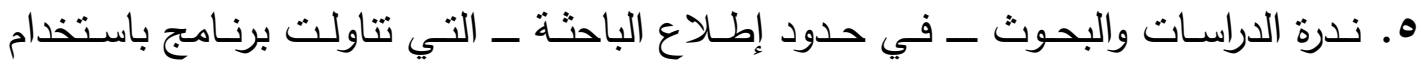

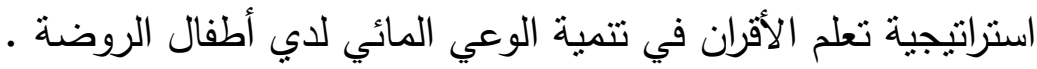

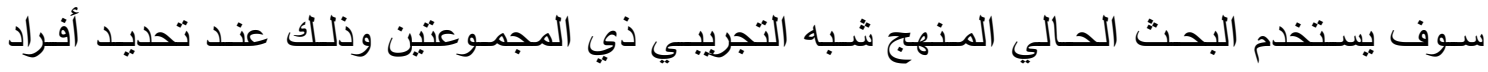

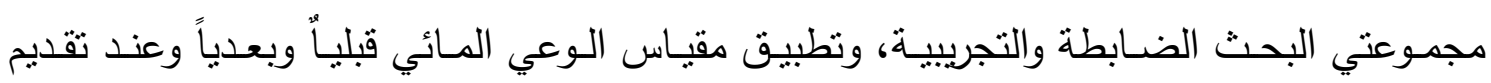
البرنامج باستخدام استراتيجية تعلم الأقران .

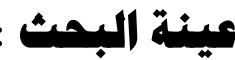

أطفال المستوب الثاني لرياض الأطفال من سن (0-7) سنوات من رياض أطفال طما الابتدائية

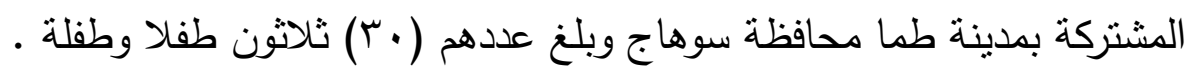

\section{توزيع أفراد العينة توزيمكا إعتداليها :}

قامت الباحثة بالتأكد من مدى اعتدالية نوزيع أفراد عينة البحث في ضوءء مقياس الوعي

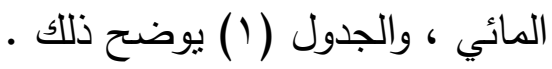

جدول (1)

المتوسط الحسابي والوسيط والانحراف المعياري ومعامل الالتواء للعينة قيد البحث في مقياس الوعي المائي

\begin{tabular}{|c|c|c|c|c|}
\hline الالتواء & الانعراف & الوسيط & الحسابي & المتغيرات \\
\hline $.10-$ &. .91 & r... & T.90 & الوعي المائي \\
\hline
\end{tabular}

$$
\text { يتضح من جدول (1) ما يلي : }
$$

• بلغ معامل الالتواء للعينة قيد البحث فى مقياس الوعي المائي (-10 .•) أي أنها انحصرت ما بين (-r ، +r) مما يشير إلى أنها تقع داخل المنحنى الاعتدالي وبذلك تكون العينة موزعة توزيعاً إعندالياً . 


\section{تكافؤ مجموعتي البحث :}

قامت الباحثة بإيجاد التكافؤ بين المجموعتين الضابطة والتجريبية فى ضوء مقياس الوعي

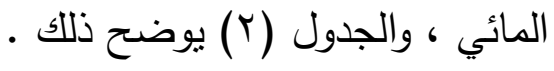

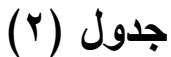

دلالة الفروق بين القياسين القبليين للمجموعتين الضابطة والتجريبية

في مقياس الوعي المائي

\begin{tabular}{|c|c|c|c|c|c|c|}
\hline \multirow{2}{*}{ الدلالة } & \multirow[b]{2}{*}{ قيمة ت } & \multicolumn{2}{|c|}{ المجموعة التجريبية } & \multicolumn{2}{|c|}{ المجموعة الضابطة } & \multirow[b]{2}{*}{ المتغيرات } \\
\hline & & الانحراف المعياري & الحستوسط & الانحراف المعياري & الحستوسط الحسب & \\
\hline غير دال &.$r q$ &. .99 & Y.q. &. .91 & r... & لوعي المائي \\
\hline
\end{tabular}

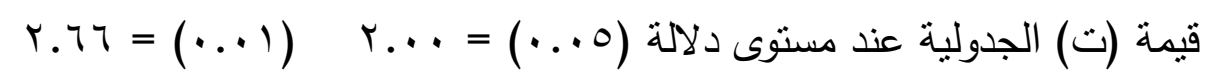

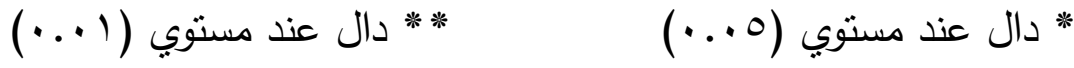

$$
\begin{aligned}
& \text { يتضح من جدول (r) ما يلي : (ب) }
\end{aligned}
$$

توجد فروق غير دالـة إحصـائياً بين مجموعتي البحث الضـابطة والتجريبيـة فى مقياس

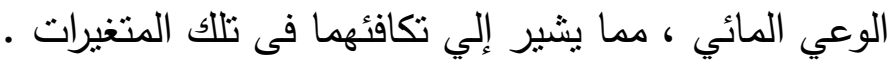

1- البرنامج المقترح باستخدام استراتيجية تعلم الاقران لتتمية الوعي المائي لدي طفل الروضة

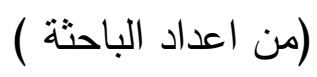

ץ- دليل المعلمة لتقديم البرنامج المقترح باستخدام استراتيجية تعلم الاقران لتتمية الوعي المائي

$$
\begin{aligned}
& \text { لادي طفل الروضة (من اعداد الباحثة ) } \\
& \text { r- اختبار رسم الرجل لجوادنف هاريس • } \\
& \text { ع - مقياس الوعي المائي لطفل الروضة. (من اعداد الباحثة ) }
\end{aligned}
$$

مصطات البمث:

في ضوء الخلفية النظرية المنضمنة في البحث، يمكن تحديد مصطلحاته اجرائياً على النحو النالي: استراتيجية تعلم الأقران: تعرف اجرائياً بأنها "نظام تعليمي يساعد فيه الأطفال بعضهم

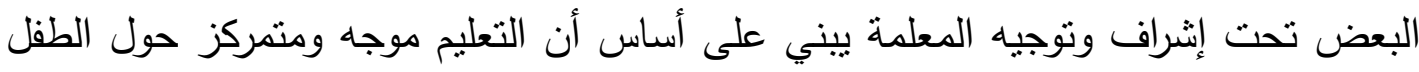
وتكون فيه بيئة التعلم فعالة مع الأخذ في الاعتبار أن يكون الطفل (القرين)المعلم من الفئة 
الوعي المائي: ويعرف إجرائياً بأنه إحساس الطفل بالقضايا والمشكلات المتعلقة بالمياه والموارد المائية ودوره نحو ترشيد استهلاكها والحفاظ عليها بشكل حكيم يظهر في السلوكيات المرتبطة بحياته اليومية ويقاس في البحث الحالي من خلال مقياس الوعي المائي.

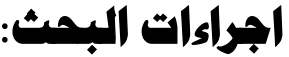

سار البحث وفقاً للإجراءات التالية:

ا. الاطلاع علي المراجع والدراسات السابقة والأطر النظرية التي تتاولت التربية المائية

عامة والوعي المائي خاصة واستراتيجية تعلم الأقران وذلك لإعداد الإطار النظري

للبحث وأدواته اللازمة لتحقيق أهدافه.

ץ. إعداد البرنامج المقترح باستخدام استراتيجية تعلم الأقران في تتمية الوعي المائي لدي

أطفال الروضة، وذلك عن طريق:

أ- - تم الاطلاع على البحوث والدراسات السابقة ونتائجها التي تخص الوعي المائي مع

مراعاة الخصائص العمرية لتلك المرحلة.

ب- تم اعداد البرنامج وعرضه على (V) سبعة من المحكمين ملحق ( () لأخذ آرائهم حول

أهداف البرنامج ومدي وملاعمتها لأطفال الروضة ونت اجراء التعديلات وفقاً لآراء

المحكمين [ملحق (r)].

ت- تم اعداد دليل المعلمة ملحق (ع) لتطبيق البرنامج المقترح باستخدام استراتيجية تعلم

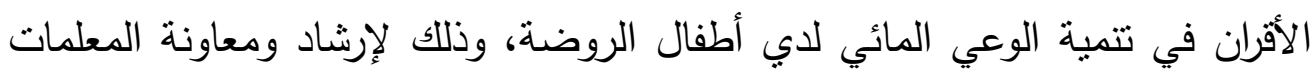
والقائمين على تطبيق البرنامج عن كيفية التطبيق، الهدف العام من البرنامج، الفئة المستهوفة، محتوي البرنامج، التوزيع الزمني، المهارات المنطلب نتافرها للتعامل مع البرنامج، منطلبات تتغيل البرنامج، دور القائم علي التطبيق، دور الأطفال. ث- تم تجريب البرنامج في صورته النهائية ملحق (r) على مجموعة من الاطفال تمثل المجتمع الاصلي قوامها (7 (1) ستة عشر طفلاً وطفلة ولكنها ليست عينة البحث للنأكد من صلاحيته للنطبيق واجراء التعديلات المناسبة. r. إعداد مقياس الوعي المائي لطفل الروضة، وعرضه على المحكمين ملحق (0) واجراء التعديلات المقترحة ملدق (T) ثم تطبيقه على عينة ممثلة للمجتمع الأصلي ولكنها 
ليست عينة البحث قوامها (1 ا (1) ستة عشر طفلاً وطفلة للتأكد من صدقه وثباته وصلاحيته للنطبيق.

ـ. اختيار عينة البحث وهم أطفال المستوي الثاني لرياض الأطفال من سن (0-7) سنوات

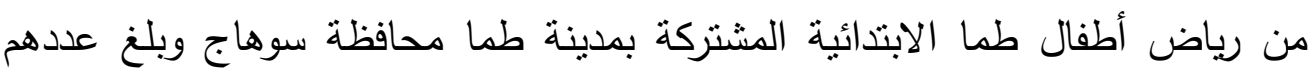
(7) سنون طفلاً وطفلة، وذللك حيث أنها مقر عمل الباحثة ومعرفة الباحثة لأسرة الروضة مما بسهل لها عملية التطبيق. ه. اجراء التطبيق القبلي لاختبار رسم الرجل (لجوادنف وهارديس) ملحق (V)، ثم مقياس الوعي المائي المصور لأطفال الروضة ملحق (؟) - من اعداد الباحثة. ج. نطبيق الباحثة للبرنامج المقترح -من اعداد الباحثة - ملحق (r). V. اجراء التطبيق البعدي لمقياس الوعي المائي الدصور لأطفال الروضة ملحق (؟) -

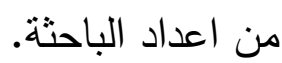
^. اجراء المعالجة الاحصائية لتحليل البيانات وتفسير النتائج. 9. نقديم بعض التوصيات والبحوث المقترحة على ضوء نتائج البحث. ثانياً - الإطار النظري للبحث: في ضوء ما يهدف إليه البحث الحالي، وفي ضوء فرضه الذي يحاول التحقق منه، وسؤاله الذي الأبي يحاول الإجابة عنه، فإن الإطار النظري لهذا البحث جاء متتاولاً محورين رئيسيين هما: الوعي المائي، واستراتيجية تعلم الأقران.

\section{المهر الأول: الومي الماتي:}

يعد الماء ضرورة من ضروريات الحياة وأصبحت قضية المياه والوعي بمشكلاتها من أكثر المشاكل التي نتغل العالم في السنوات الأخيرة نظراً للنقص المتزايد في كميات المياه المتاحة والصالحة للاستعمال ، لذلك أصبح الوعي المائي ضرورة حتمية من خلال الاستخدام الأمثل لموارد المياه ودعم جهود المؤسسات المختلفة لتتمية الوعي المائي للمحافظة علي المياه.

\section{هفهوم الوفي الماتي:}

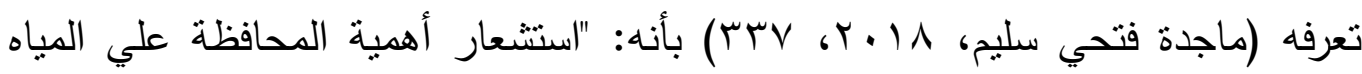

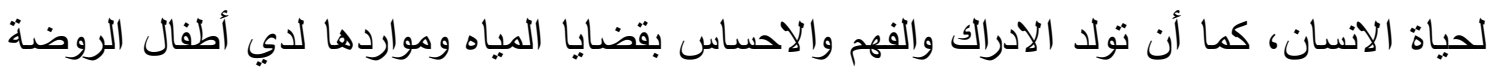
سوف يجعلهم يتعاملون بحكمة ورشد مما يجعلهم يحافظون عليها". 


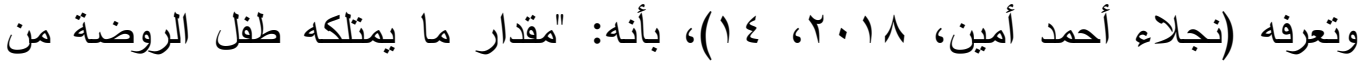

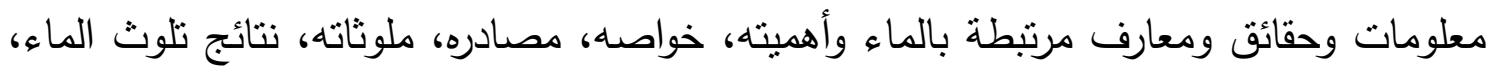
وما لديه من ميول واتجاهات نحوها، والكيفية التي يتصرف بها في المواقف والمشكلات المنصلة

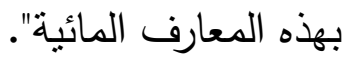

ويتضح من التعريفات السابقة أن الوعي هو القدر المناسب لما يمتلكه طفل الروضة من معلومات ومعارف وحقائق تخص قضايا المياه ومواردها بما يدعم السلوكيات المائية المرغوب فيها لهريا لاي الطفل ويشعره بأهمية المحافظة علي المياه.

ان تتمية الوعي المائي لاي أطفال الروضة بمكنه أن بسهم في تتشئة جيل قادر علي مواجهة مشكلة المياه، والمشاركة الفعالة في حلها، وبخاصة من خلال السلوكيات الإيجابية الني

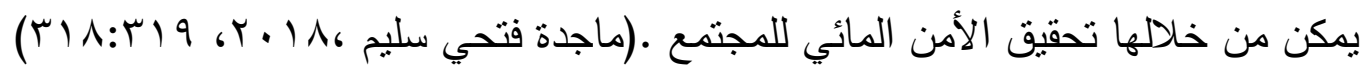

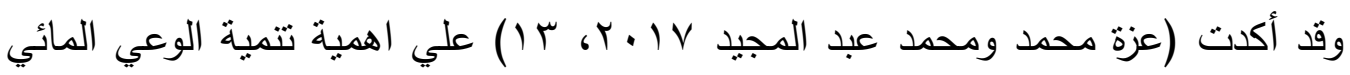

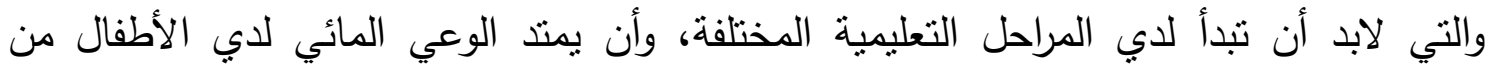

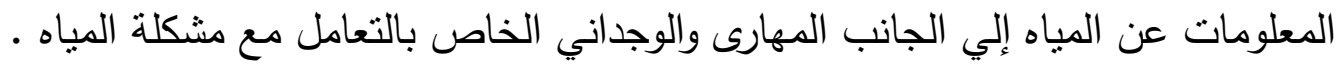
وقد أظهرت أدبيات البحث العديد من الأسباب التي تدعونا لتتمية الوعي المائي يمكن

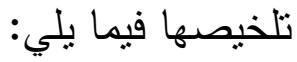

ندرة الموارد المائية منذ سنوات وتفاقم هذه المشكلة مع مرور الوقت وذللك نظرا لسوء الاستخدام ،وزيادة الطلب علي المياه لمواكبة تطورات العصر في كافة قطاعات التتمية. والزيادة السكانية الهائلة، والماء المفقود نتيجة العادات

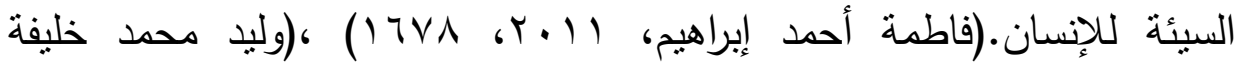
.$\left(T_{T}, T^{\prime} \cdot 19\right.$

سوء استغلال الانسان لبيئته المائية وذلك من خلال استنزافه للموارد المائية العذبة وتلويثه لمجاريها ومسطحاتها مما ساعد في ظهور الكثير من المشكلات المائية.)

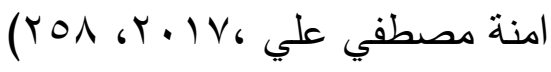
الحد من إمكانبة حدوث حروب علي المياه سواء على المستوي المحلي 
• الجهل، ونقص الوعي بقلة ومحدودية الموارد المائية

• عدم وجود المسئولية الاجتماعية؛ فالمسئولية ليست للحكومات فحسب وإنما أيضا

مسئولية مشتركة مع الثعوب، اذ أن علي الجماهير أن تتحمل العواقب، وتنساهم بوعيها وسلوكها في الحد من الاسراف في استعمال المياه، خصوصا في الزراعة ثم الصناعة ثم المنازل وغير ذللك فكل قطرة مياه هي بالفعل حياة. ( Lumyai Seehamat1, Unchalee Sanrattana1 \& Angkana

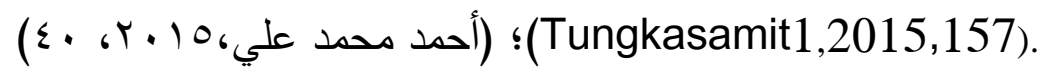
الطفل في البداية تتكون لديه الكثير من المفاهيم وأنماط السلوك الغير مرغوب فيها. أهمية الماء وخطورة قضاياه، ولكون السلوك البشري له دور كبير في حدوث الكثير من المشكلات المائية فقد أوصت العديد من المؤتمرات والندوات العلمية بأهمية دور التربية في مواجهة المشكلات المائية المختلفة، باعتبارها الوسيلة الفعالة التي تساهم في تتوير الأفراد بأهمية الماء وتوعيتهم بالموارد المائية في

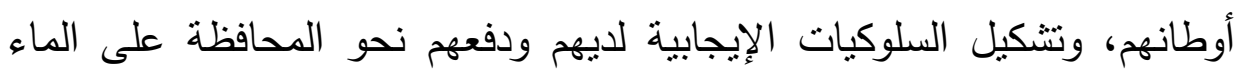
وحمايته من الاخطار التي تهدده وحل مشكلاته. (تهاني حسونة، ع (.ب، ع: 0). ومما سبق تتضح لنا أهمية تتمية الوعي المائي في مرحلة الطفولة عامة وخاصة لدي

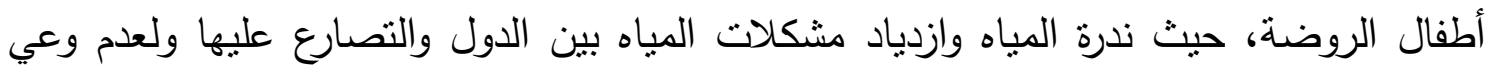

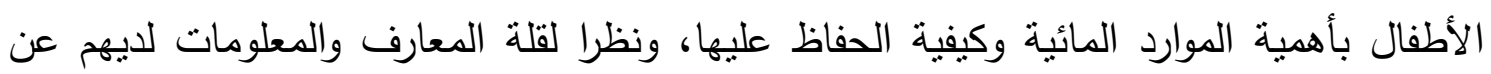
المياه وكيفية الحفاظ عليها بما يسلكونه من سلوكيات ويمارسونه من عادات تؤدي إلي اهدار المياه واستنزافها وتلوثيها وكثير من المشكلات الأخرى ؛ لذا وجب تنمية الوعي في هذه المرحلة لكونها

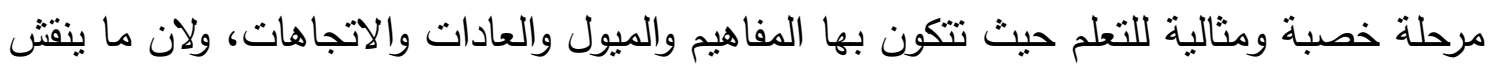
في صفحة الطفل البيضاء في هذه المرحلة يصعب تعديله فيما بعد لذا وجب علينا استغلال تلاكي المرحلة من حياة الطفل في تتمية الوعي المائي لايهم واكسابهم المعارف والمهارات والاخلاقيات

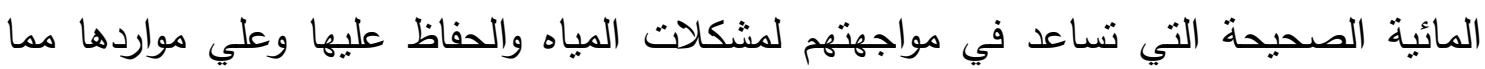
يسهم بجيل قادر علي مواجهة المشكلات وحلها بنحو يحقق جوانب التتمية المختلفة . 


\section{مراحل تنمية الوعي المائي:}

برامج التوعية ورفع الوعي المائي لن تستطيع تحقيق أهدافها وغاياتها من خلال تتفيذها

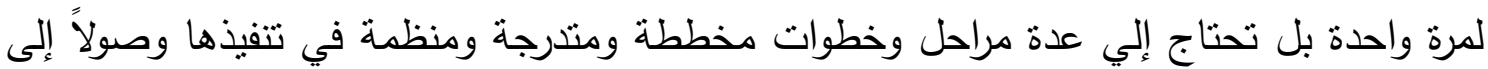

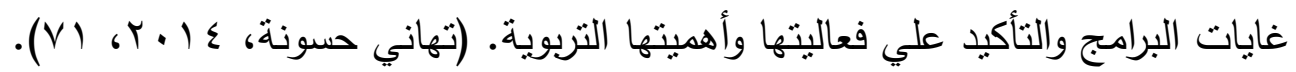

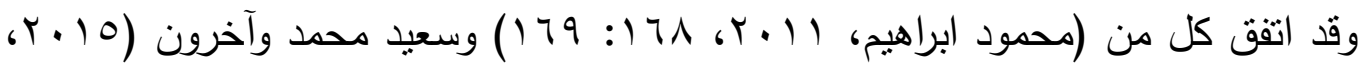

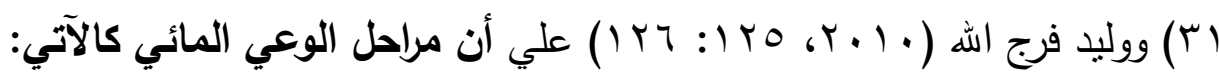

مرحلة التقييم أو المرحلة التمهيدية

وفيها ينبغي تحديد ما لدي الطفل من معارف ومهارات ومفاهيم وسلوكيات متصلة بالماء أو الوعي المائي، حيث أنه لا يصح أن تقدم خبرات جديدة للأطفال إلا إذا اتضحت الروئية للها يوجد لديهم من معلومات سابقة.

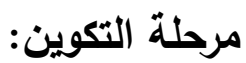

ويتم في هذه المرحلة اختيار الخبرات أو المداخل المناسبة لتكوين الوعي لدي الأطفال والتي تجذب انتباههم.

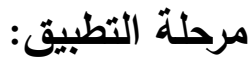
وهذه المرحلة يناح للأطفال التفاعل مع المواقف والخبرات ليطبقوا ما سبق تعلمه من

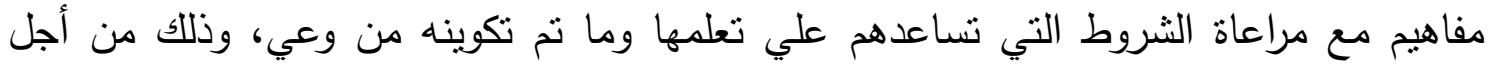
التأكد من أن ما حدث من تعلم له آثار باقية ومؤثرة في عقل ووجدان وسلوكيات الطفل فما سبق تعلمه لابد أن يجد الفرصة للنطبيق والممارسة.

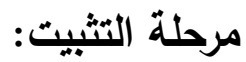

وفيها يقوم المعلم بالتخطيط لمواقف تعليمية لتوسيع ما سبق تعلمه وتكوينه من المفاهيم والتأكيد عليها يكون من شأنها أن تعزز تدعم ما سبق تعلمه.

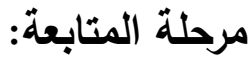

وهذه المرحلة تتطلب أن يوفر المعلم مواقف تعليمية جيدة بنشط بها الأطفال ويمارسوا بها

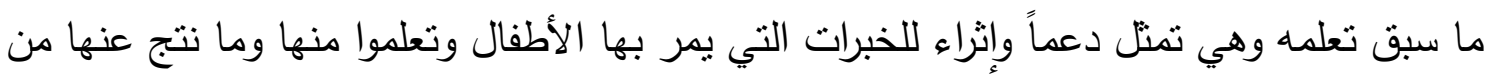




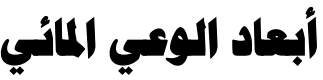

الوعي يمنل أحد المستويات المكونة للجانب الوجداني بل هي أولي مستوياته حسب المبان

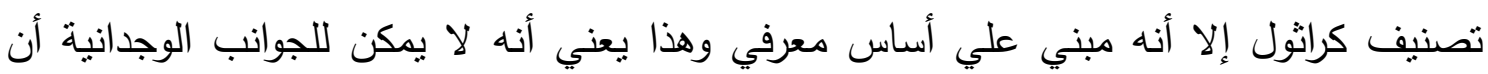

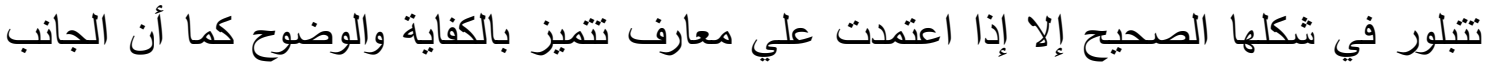

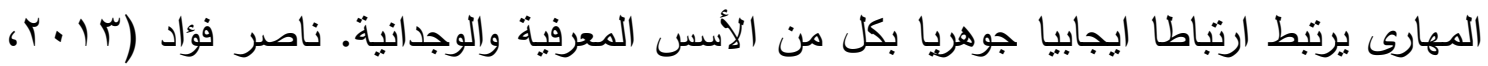
.$(r) \mathrm{V}$

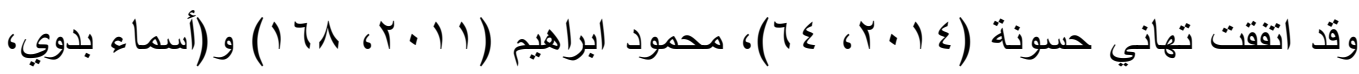

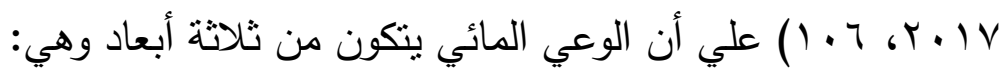

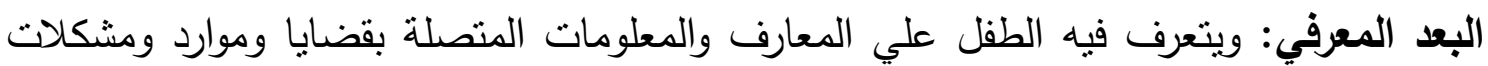
المياه. البعد الوجداني: وتتتكل فيه لدي الطفل الميول والاتجاهات الايجابية نحوها. البعد المهارى (الأدائي أو التطبيقي أو التوعي) ويتضمن هذا البعد محصلة البعدين السابقين حيث

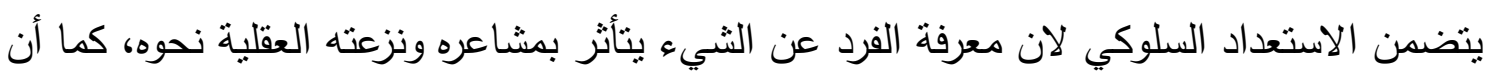
تغيير معرفته عن هذا الثنيء يتزتب عليه تغيير مثاعره ونزعته العقلية نحوه فينهج الفرد سلوكا ترشيدياً نحو التعامل مع القضايا والمشكلات المائية.

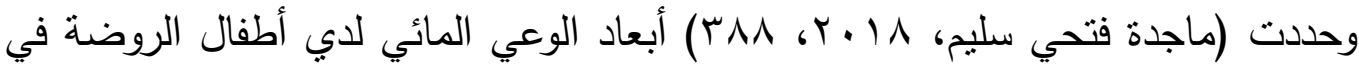

بعدين رئيسيين هما: ترشيد استهلاك المياه وعدم الاسراف فيها سواء في المنزل أو في الروضة أو الحديقة.

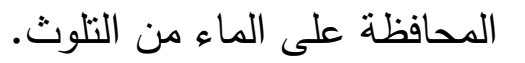

كما أوضحت أنه بتتمية هذين البعدين لدي أطفال الروضة من شأنه أن يسهم في اعداد جيل لديه الحكمة في استعمال المياه والدحافظة عليها، وتلوثه، وتعد من السلوكيات الخاطئة التي لئي تزيد حجم المشكلة المائية.

\section{دور الموسسات التعليمية في تنمية الومي الماني:}

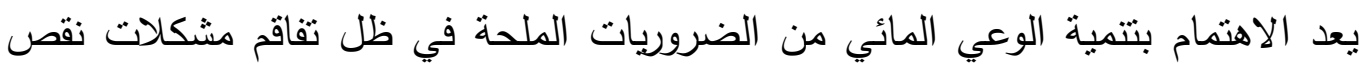
المياه واستنزافها وتلويثها وزيادة سلوكيات الأطفال السيئة تجاه المياه، نتيجة لنقص التصات الوعي الميائي

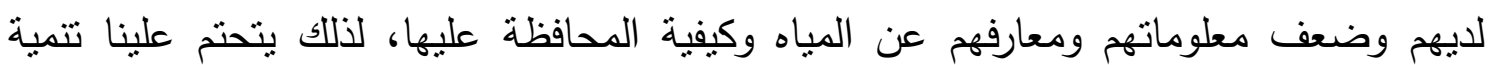


الوعي المائي لديهم، وتستطيع المؤسسات التعليمية عامة ورياض الأطفال خاصة تتمية مستوي

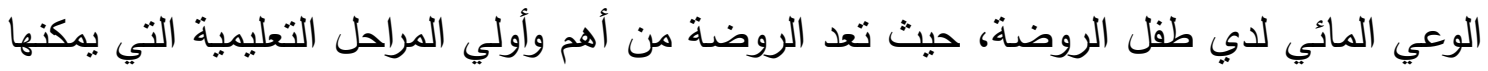

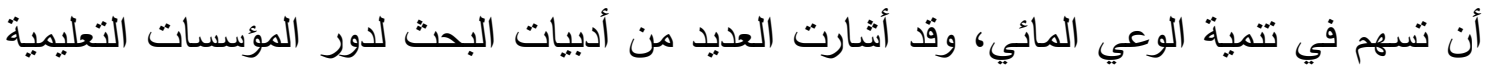

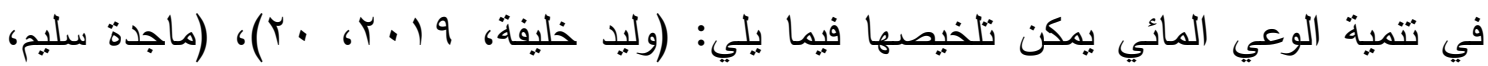

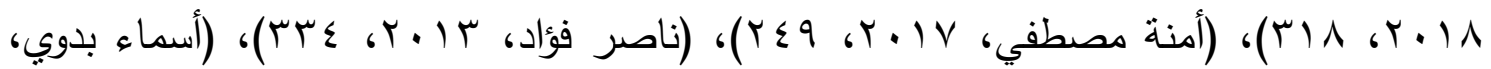

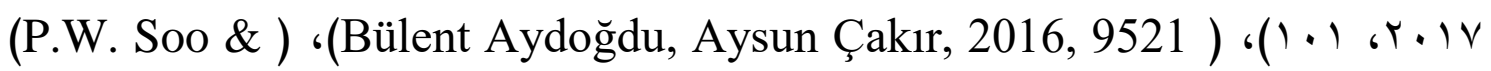

.C.S. Cheam, 2012 • ضرورة اهتمام المناهج الدراسية بتتمية الوعي المائي لدي الأطفال في مرحلة مبكرة من العمر ، من خلال نطوير المناهج والمقررات التعليمية للرفع من الوعي والادراك لكيفية المحافظة على هذا المورد الهام والحيوي، وذللك بإكسابهم الحقائق والمفاهيم والتعميمات المرتبطة بقضايا المياه ومشكلاتها، فضلاً عن اكسابهم مهارات التعامل الجيد مع المياه، وتتمية الاتجاهات والقيم المرغوب فيها نحوها للحفاظ عليها واستثمارها لأقصي حد. متل دراسة ماجدة سليم (1 (ب)، ودراسة نجلاء أمين (10 · ب)، ودراسة اميلي ايفانز (EMILY EVANS, 2012). تضمين الأنشطة اليومية المقصودة بمجموعة المعارف والمهارات والسلوكيات والقيم الإيجابية

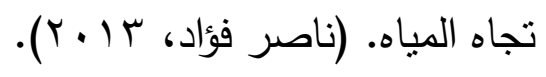
تتويع الأنشطة التعليمية المرتبطة بالمياه والمحافظة عليها مثل: دمج الألعاب والأغاني والتجارب. (Amanda Justine Horvath. 2010, 16)

\section{المهور الثاني: استراتيبية تعلم الأقران}

إن التقام بالعملية التعليمية التي فرضته الاتجاهات التربوية المعاصرة من الاهتمام بالمادة الدراسية او بالمعلم إلى الاهتمام بالمتعلم وجعله محور العملية التعليمية وتفعيل دوره، ولإثارة دافعيته نحو التعلم، صاحب ذللك تطور في أساليب وطرائق التنريس. وقد أولت التربية أهمية كبيرة للاستراتيجيات التنريس، واعتبرتها حجز الزاوية في العملية التعليمية لما لها من دور في تحقيق أهداف العملية التعليمية وتتمية المفاهيم والاتجاهات كما أنها من الضروريات لعملية التدريس الناجح ووسيلة لنقل المعلومات والمعارف والمهارات إلي الطفل، وهي وسيلة للاتصال به والتفاعل معه وتتظيم أنشطته وسلوكه وابداعاته لتحقيق أهداف التعليم،

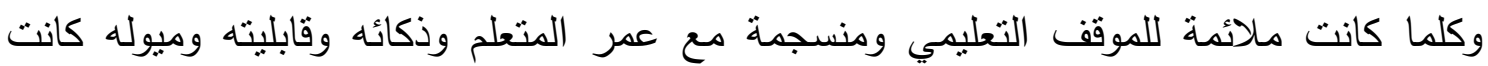




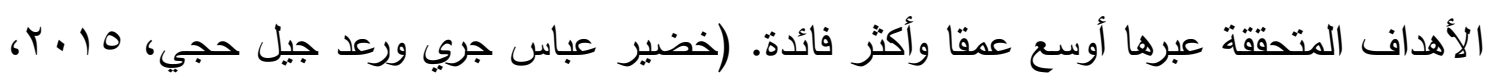

$$
\text { ) ( }
$$

ويعد تعلم الأقران من الاستراتيجيات الحديثة التي تتدرج في مضمون التعلم التعاوني، والتي تستخدم في التدريس بهدف إحداث تغيرات إدراكية وعاطفية واجتماعية وحركية ، وهذه التغيرات

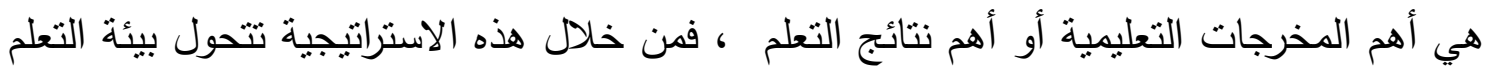
التقليدية إلي بيئة تعلم تفاعلية يتغير فيها دور المعلم ليصبح موجها للمتعلمين يستثير دافعيتهم

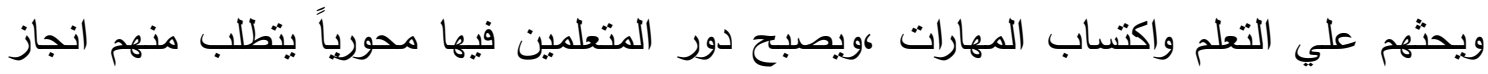

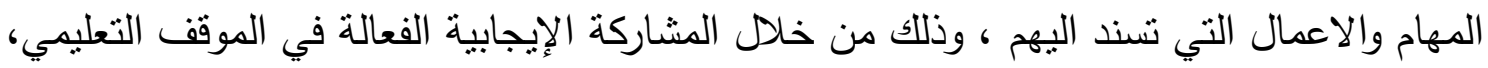

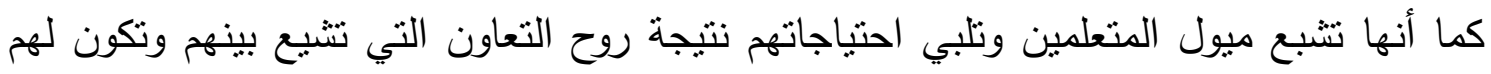

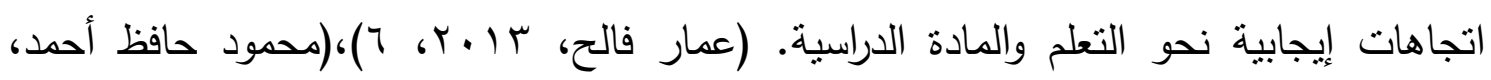
(10, r. 1 14

فهي استراتيجية تعزز ما وراء المعرفة وبمعدل أسرع مما يمكن تحقيقه عند عمل التلميذ

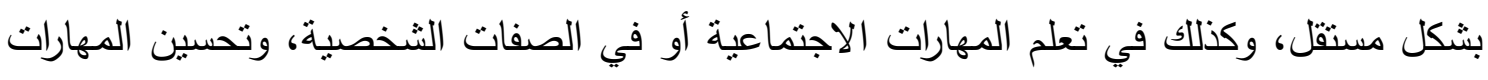

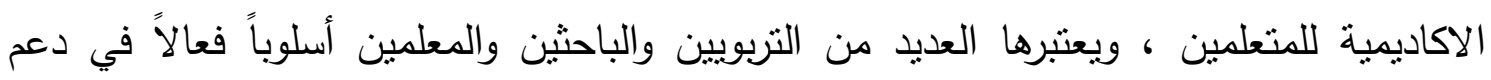

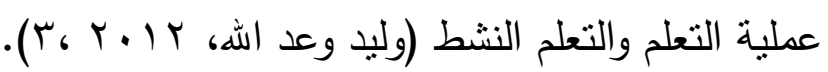

وقد أوصت العديد من الدراسات مثل دراسة (ثثاء سعيد حسن وهند على حسين، 19 ـ ب)

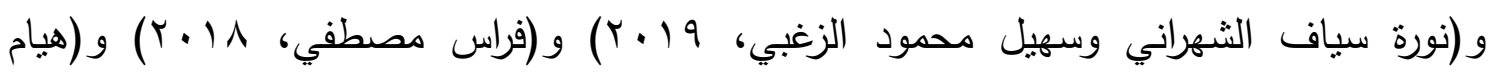

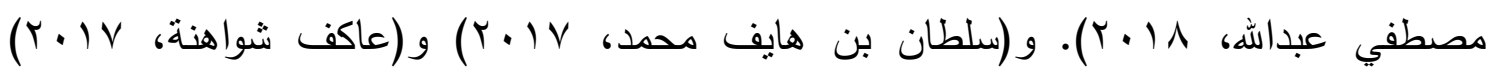

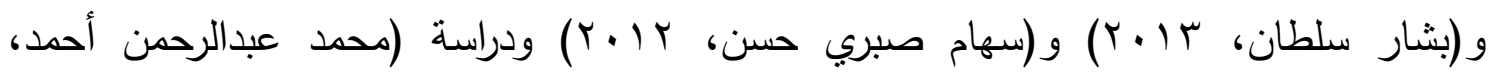
(Y) استراتيجية تعلم الأقران في المراحل التعليمية المختلفة، وفي تدريس المواد الدراسية المختلفة حيث

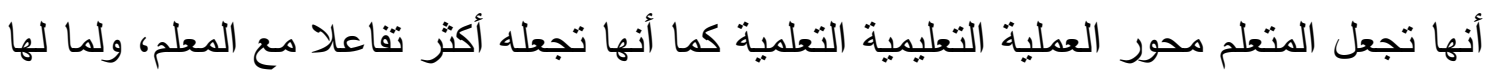
من أثز إيجابي وفعال في عملية التدريس.

وقد أكد (Jennifer Fager, 1996, 6) أن تعلم الأقران جزء لا يتجزأ من كل يوم لأطفال

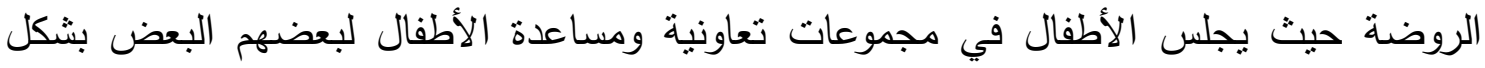

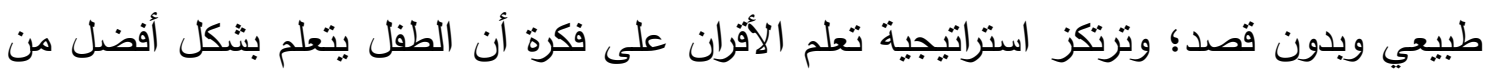

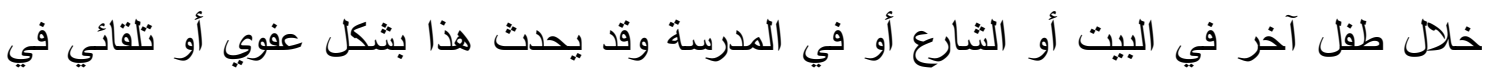

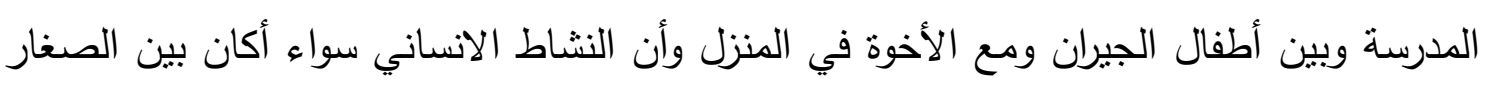




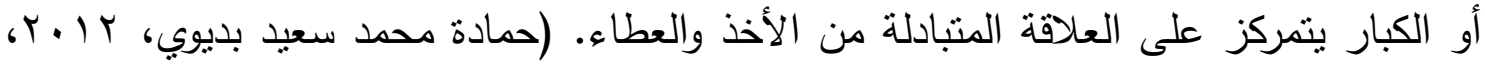

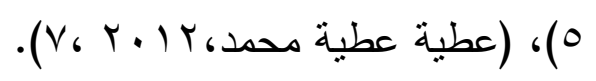

كما تعتمد هذه الاستراتيجية على قيام الطفل بتعليم اقرأنه المهارة المستهدفة، من خلال

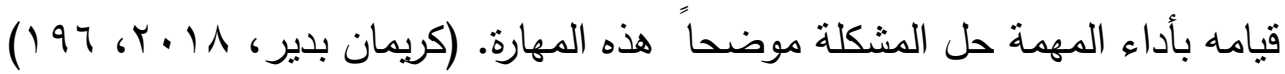

\section{مفهوم استراتئية تعلم الأقران: -}

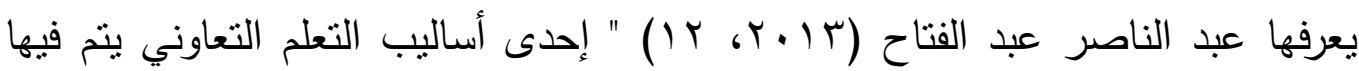
تعلم التلاميذ ذو التحصيل المنخفض (القرين المتعلم من زملائهم ذوي التحصيل المرتفع (القرين المعلم) ويتم في ثنائيات بين تلميذين أحدهما منمكن من المهارة المحدة يقوم بدور المعلم والتلميذ الأخر غير متمكن من تلك المهارة ويكون هو المتعلم ثم يحدث تبادل الأدوار ويتم تدريب (القرين المعلم) علي القيام بتلك المهمة ".

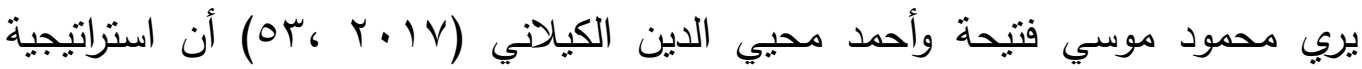
تدريس الأقران هي استراتيجية يقوم فيه الطالب ذو الكفاءة العالية بممارسة دور المعلم القربن مع الأقران المتعلمين لتقديم العون في تحسين أداء مهارات متتوعة.

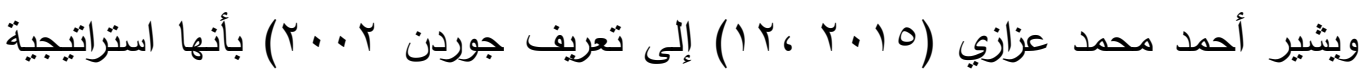
تعليمية يقوم فيها طفل بتعلم طفل آخر مادة أو مهارة ما يكون فيها الطفل المعلم أكثر خبرة ومهارة من، بينما الطفل المتعلم يكون أقل خبرة ومهارة لأن هذه المهارة لم يكتسبها من قبل. ويعرفها حمادة محمد سعيد بديوي (Y ( + Y، Y) استراتيجية تعلم الأقران تعني باختصار

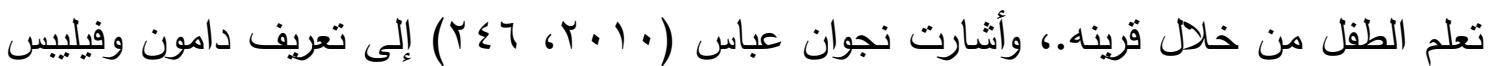
9 919 والذي تعتبره التعريف الأكثر ايجازا بأن تعلم الأقران طريقة يعلم فيها الطفل طفلاً أخر مادة ما حيث يكون الأول خبيرا أو متمكنا منها أما الثاني فيكون مبتدئ. لئرون

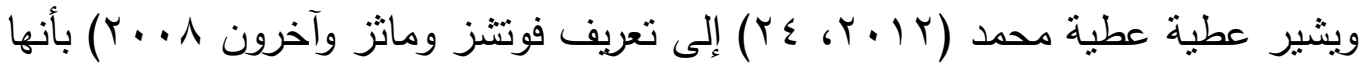
مجموعة من الأنشطة التي تساعد المتعلمين عي تعلم وممارسة المهارات الأساسية والمهارات المعرفية العليا، وتتميز انشطة تلك الاستراتيجية بأنها محسوسة ومحدة ومحببة للأطفال كما أنها طريقة تدعيميه وتوفر التغذية الراجعة والأدوار المتبادلة بين الأقران. وتعرفها الباحثة بأنها عملية تعليمية تبادلية يقوم فيها الطفل القرين المعلم بتعليم الطفل القرين المتعلم مهارة أو نشاط ويكون فيها الطفل القرين المعلم منمكنا من المهارة، ويكون الطفل القربن المتعلم أقل خبرة أو لم يكتسب المهارة من قبل ويتم ذلك تحت اشراف وملاحظة المعلمة. 


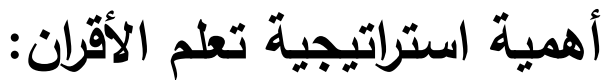

اشارت العديد من الأدبيات التريوية لأهمية تعلم الأقران والتي يمكن اجمالها

تزيد من فههم لما يتعلموه حيث تجعل الطفل أكثر قدرة على تنظيم المعرفة وأكثر فهما، فتسهم في تتمية التحصيل الأكاديمي؛ كما تساعد في نطوير المهارات اللغوية عند الأطفال ومهارات التحدث والاستماع والقراءة والكتابة؛ ومهارات الاتصال بواسطة أنشطة التفاعل الثنائي بين القرناء؛ حيث أكدت النتائج علي أن الأطفال الذين تعلموا القراءة من خلال الأقران أفضل من الأطفال الذين تعلموا القراءة بدون أقرانهم؛ كما أكدت دراسة (Silvia Blanch, 2012) فعالية تعلم الأقران في تحسين مستوي القراءة

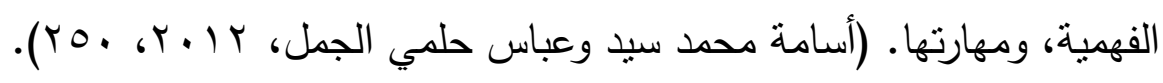
تتمية المهارات الاجتماعية وتقدير الذات بصورة ايجابية تساعد في جعل الطفل يتحمل المسئولية والاستقلالية والاحساس بالفاعلية، يولد الاحساس بالجماعة ويعلم المتعلمين التعاون والمشاركة في صنع القرار ويساهم في النمو الاجتماعي لديهم، وتتمية مفهوم

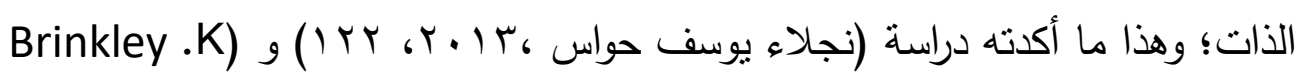
2011, 1)كما أكدت دراسة (Penelope,2010,85) على فعاليتها في اعتماد وتتمية الدور القيادي لدي الطفل.

Candice \& ) تساعد في تعليم مهارات الأمان للأطفال وهذا ما أكدته دراسة other's,2008)

• يساعد في القضاء على الملل وجعل المادة التعليمية مثيرة للتعلم؛ واقتصادية موفرة

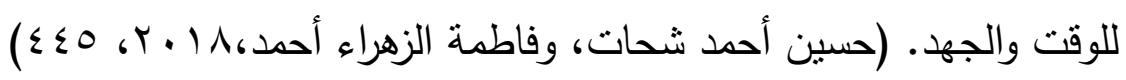
بحسن من السعة العقلية للقرين المعلم حيث يساعد القرين المعلم علي تتظيم المعرفة وتتظيم أفكاره واستخدام استراتيجيات تفكير أكثر مرونة وشراسة فهي وسيلة جيدة لتنكر

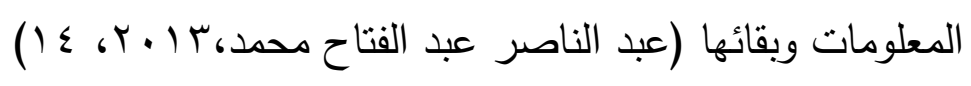


• توفر للطفل المتعلم شخص ينتبه اليه ويعمل معه بما يتتاسب مع مستواه التعليمي ويقوم بالتكرار له وتقديم التغذية الراجعة المباشرة؛ فالطفل يمكنه أن يسأل قرينه بصورة أفضل عن معلمه؛ فالتغذية الراجعة التي يقدمها الأقران تؤثر علي تحسين المهارات اللفظية وأنها استراتيجية فعالة في خفض السلوكيات غير المرغوبة التي تؤثر على لتى

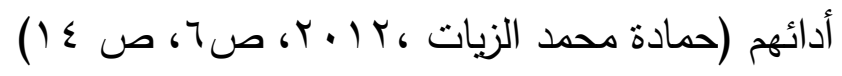

تساعد الطفل أن يتعلم من خلال الأقران والزملاء بواسطة حواسه الخمس، كما تتوفر لديه وسائل قوية للإدراك والتعلم المتمنلة بوسائل الادراك وأن صيغ معالجة المعلومات التي يتخذها في التعلم هي التسلسل، التفصيل، التغاير، التتابه، التبويب، الاستقراء، الاستتاج إذ يتعلم الطفل بواسطة أقرانه ونقانشه وتبادلهم الآراء. (وفاء عبد الرزاق،

$$
\cdot(r T V, T \cdot)
$$

تمكن المعلم من زيادة مستوي التعاون بين الأطفال في حجرة الصف وتعطبه فرصة لملاحظة جميع الأطفال. (فاطمة عبد الحميدٌ أبو النوارج واخرون ،9 1 ـ ب، 0 1). • استخدام استراتيجية نعلم الأقران يوفر بيئة آمنة للتجريب والمحاولة والخطأ دون عقاب

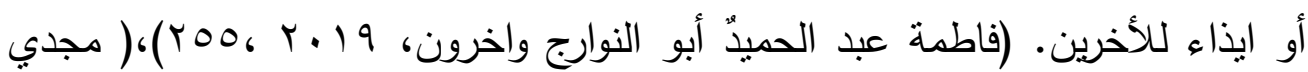

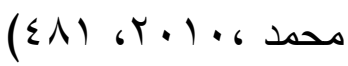

• تمنح القرين المعلم الثقة بالنفس وتتيح الفرصة للتعلم والتعاون ،وأخذهم لدور المعلم أو المدرس في تعليم أحدهم للاخر ، دون قيود مفروضة من المعلم. ، كما تزيل الحرج لهاج من القرين المتعلم عند اعطائه أو ذكره لإجابات خاطئة.

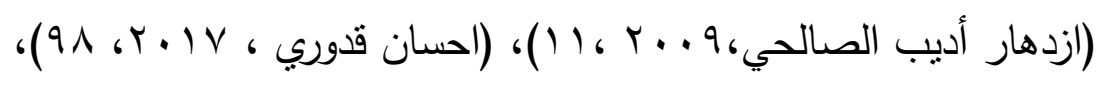

تجعل أنشطة التعلم مركزة حول الطفل بدلا من تركيزها حول المعلمة بحيث يصبح

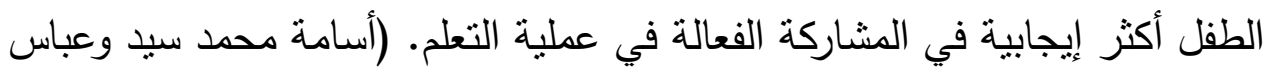

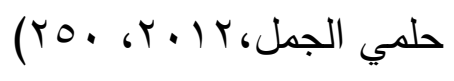

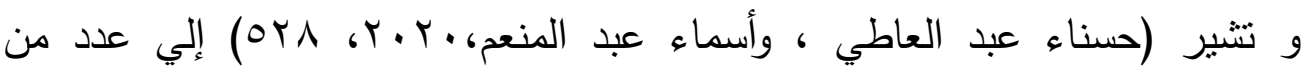
المميزات التي تدعو لتفعيل استراتيجية تعلم الأقران في العملية التعليمية والاستفادة من دورهم ، حيث يساعد هذا الدور علي الأتي : لئي 
• انجاز المهام وتحقيق التعاون والتواصل بين الأفراد.

تتمية التحصيل المعرفي ونواتج التعلم في المجالات المختلفة.

• التقليل من فرص الثعور بالإحباط .

وتلخص الباحثة أهمية استراتيجية تعلم الأقران في أنها نتفر بيئة تعليمية جيدة متمركزة حول الطفل حيث تساعد في القضاء علي الملل وتوفر جو من النتويق والمتعة، وتتمي لديه العديد من المهارات كمهارات اللغة والاتصال والمهارات الاجتماعية، وتزيد من الدافعية للتعلم ومهارات

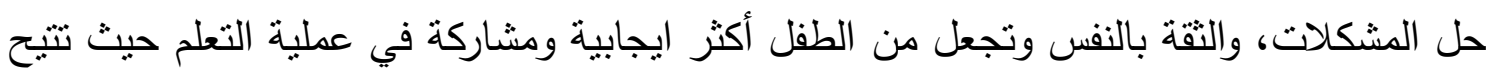

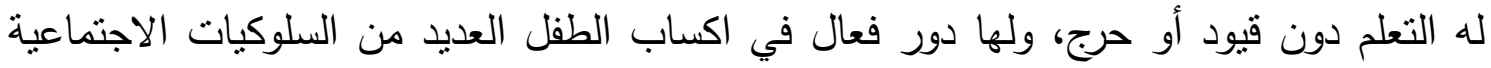
المقبولة، كما أنها نساعد المعلمة في توفير الوقت والجها وتمنحها فرصة أكبر لملاحظة الأطفال أثناء عملية التعلم وتقويمه.

\section{الأسس النظرية القائمة عليها استراتيجية تعلم الأقران:}

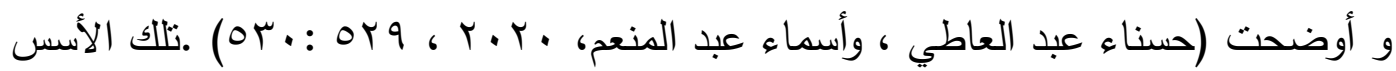
علي النحو التالي :

1. نظرية النمو المعرفي التي وضعها جان بياجه وأثنار من خلالها علي أنه علي المتعلم التواصل والتفاعل والتشارك من خلال مجموعات العمل في البيئة المحيطة، حتي يتعلم بشكل أفضل مما يؤدي دور هام في نمو المعرفة ،كما يحتاج المتعلم إلي الدعم والتوجيه بأنماط مختلفة لكي تزداد درجة فهمه وينتقل إلي المراحل المتقدمة في التعلم.

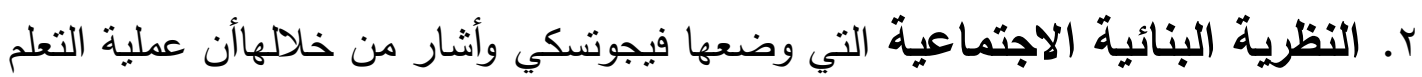
تتم من خلال التفاعل الاجتماعي الذي يحدث بين المتعلمين والمعلمين أو بين المتعلمين وأقرانهم الأكثر خبرة، وذلد لمساعدة المتعلمين علي انجاز المهام التعليمية المختلفة والتي يصعب عليهم أداؤها بشكل مستقل وحل المشكلات بأنفسهم وتخطي العقباتالتي تواجه8 بحيث يتم تقليل هذا الدعم تدريجيا لتمكينهم من الاعتماد علي أنفسهم في المواقف التعليمية

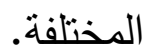


r. نظرية الحوار والتي تعتمد علي الحوار الذي يتم بين المشاركين في عملية التعلم ، حيث أنه يختلف في النوع والدرجة من متعلم لأخر ويبدأ بمناقثة عامة ثم مناقثة الموضوع ثم التحدث عن التعلم الذي تم حدوثه وفيه يكون كل متعلم مسئول عن الفائدة التي يحصل عليها الآخر ، ومن خلا مشاركة المعارف والخبرات التي لديهم.

\section{خطوات تنفيذ استراتيجية تعلم الأقران:}

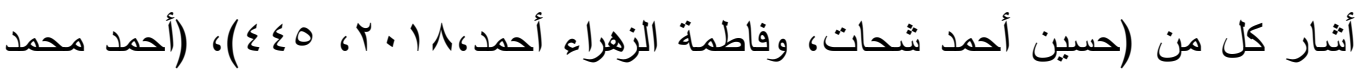

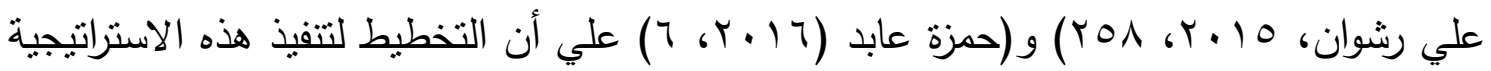

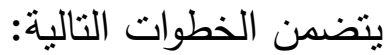

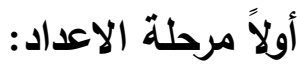

• تهيئة البيئة التعليمية حيث تتطلب هذ الاستراتيجية نوافر قدر عال من الدافعية والاستعداد لدي القرين المعلم للقيام بالتدريس للأقران وتقبل الاقران لقرينهم المعلم. تقسيم الأطفال إلى مجموعات تضم كل مجموعة قرينا معلما وأقرانا متعلمين وأطفال ملاحظين من خلال نظام تدوير المجموعات. تحديد الأدوار والمسؤوليات من تحديد لقاءات المعلمة مع الأقران المعلمين والأقران المتعمين والملاحظين لشرح المطلوب منهم وأدوار كل منهم ومسئولياته. • تحليل المهارات موضوع الدراسة تحليلا دقيقا إلي مكوناتها السلوكية وتقديمها للأطفال لدراستها بالتفصيل. • تحديد نوعية المشاركة بمعني هل يقوم القرين المعلم بالتدريس لنشاط كامل

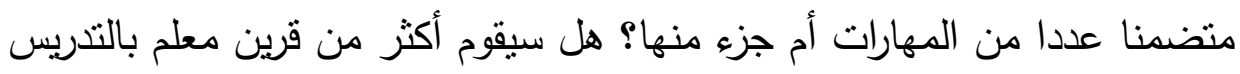

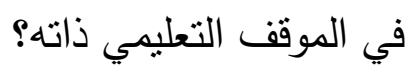
• تحديد المدة الزمنية التي سيتم فيها التنريس: هل سيكون خلال فترة نشاط كاملة

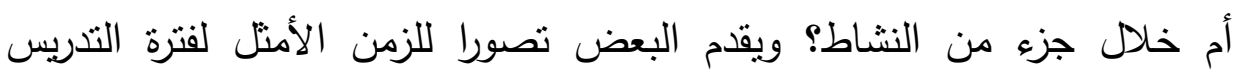
للأقران في حالة إذا كان عدد الأقران من (ع-0) أطفال، فيقترح (10 - • ب) دقيق للتدريس وخمس دقائق للنق ثم 10 دقيقة أخري لمعاودة التنريس. 


\section{• إعداد المواد التعليمية وتصميم الدروس وأدوات التقويم \\ ثانياً مرحلة التطبيق:}

• ينفذ القرين المعلم النشاط المعد على مجموعة الأقران المتعلمين في الوقت المحدد

$$
\text { لعرض النشاط. }
$$

تقوم المعلمة ومجموعة الأقران المتعلمين والملاحظين بتسجيل ملاحظاتهم على

$$
\text { أداء القرين المعلم في أثناء تنفيذه للنشاط من خلال المعلمة. }
$$

تنافق المعلمة ومجموعة الأقران المتعلمين والملاحظين القرين المعلم في الأداء

$$
\text { الخاص به من حيث جوانب القوة والضعف. }
$$

يأخذ المعلم القرين استراحة يستطيع فيها عمل تصور جديد لطريقة عرضه

$$
\begin{aligned}
& \text { للنشاط في ضوء اراء زملاؤه ومعلمته. } \\
& \text { ثالثاً مرحلة التقييم: } \\
& \text { التقييم المرحلي أثناء التطبيق. } \\
& \text { التقييم النهائي بعد التطبيق. } \\
& \text { الأنماط المختلفة لاستراتيجية تعلم الأقران: - } \\
& \text { تدريس الأقران يأخذ اشكالا متعددة وسنوضحها فيما يلي: } \\
& \text { 1. وفقا لمستوي عمر القرين (القرين المعلم والقرين المتعلم) }
\end{aligned}
$$

same - age tutoring or class wide tutoring تعليم الأقران من نفس العمر

وفيه يساعد (القرين المعلم) من نفس العمر، وفي نفس المرحلة التعليمية، وفي نفس الفصل الدراسي كل (القرناء المتعلمين) في الفصل أو فصل آخر في عملية التعلم

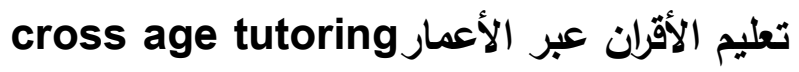

وفيه يساعد القرين الأكبر سناً والأكثر تقدما في التعليم القرناء الأصغر سنا، وعادة

$$
\text { يكون الفرق في السن من سنة إلى ثلاث سنوات تقريباً }
$$


وفقاً لعدد الأقران المشتركين في التعلم.

$$
\text { One - to -one tutoring تعليم الأقران من فرد لأخر (الثنائي) }
$$

وفيه يشترك (القرين المعلم) الأكثر مهارة مع (القرين المتعلم) الأقل في مستوي المهارة

$$
\text { ويحتاج إلي تعلمها وتتميتها. }
$$

small group tutoring تعليم الأقران من خلال المجموعات الصغيرة

وفيه نتشرك مجموعة صغيرة من القرناء (مرتفعي ومتوسطي ومنخفضي) الأداء معا في تتفيذ بعض المهام في مجموعات تعاونية.

r. وفقاً للأدوار والمسئوليات لدور كل من القرين المعلم والقرين المتعلم في التعلم.

$$
\text { • • تعليم الأقران أحادي الاتجاه (تابت): }
$$

وفيه يقوم القرين المعلم بالتدريس طوال الوقت ويظل القرين المتعلم كمستمع لقرينه.

$$
\text { • • ت تعليم الأقران ثنائي الاتجاه (التبادلي) }
$$

وهو عبارة عن ثنائي من الأقران (قرين معلم وقرين متعلم) وكلاهما يتبادلان الأدوار بين معلم

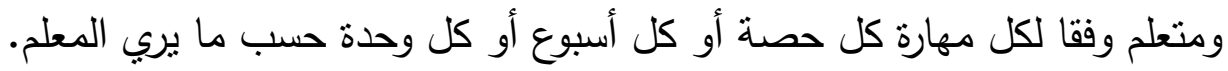
r. إنقاً لحجم المشاركة في التعلم

$$
\text { • }
$$

وفيه يقوم القرين المعلم بمساعدة المعلم الأساسي بأن يدرس الأقران بشكل كلي.

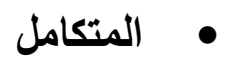

وفيه يقوم القرين المعلم بمسئوليات التدريس متكاملة.

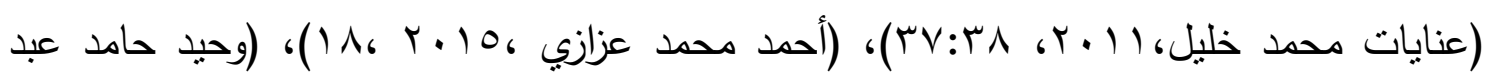

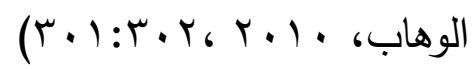

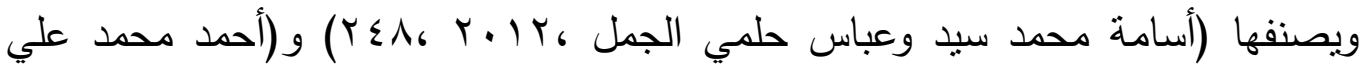

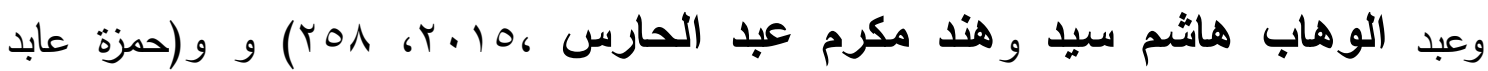

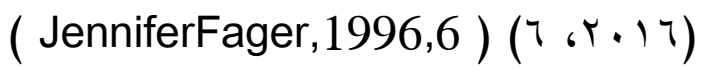


النمط الأول: (التقسيم الأفقي) تعليم الأقران من نفس العمر عبر أو بين الفصول حيث يقوم المتعلمين بمساعدة زملائهم خارج فصلهم الدراسي بحيث يكونوا في نفس المستوي العمري، وتوجد أثنكال مختلفة للتفاعلات الممكنة بين الأقران في هذا النمط ومنها:

$$
\text { نوزيع المتعلمين وأقرانهم في أزواج أو في مجموعات توزيعا عشوائياً. }
$$

توزيع المتعلمين وأقرانهم في ازواج وفقا لمعايير محددة مثل الجنس، الثخصية، التحصيل..، حيث تتم المزاوجة على أساس تلك المتغيرات سواء على مستوي الأفراد او المجموعات بشرط ان يكون هناك فروقاً في المستوي بينها حيث تتم المزاوجة بين الأطفال ذوي صعوبات التعلم مع مرتفعي التحصيل وهكذا. النمط الثاني: (التقسيم الرأسي) وهو تعليم الأقران وفقا للسن وفيه يكون القرين المعلم والقرين المتعلم مختلفين في المستوي الصفي حيث يتراوح الفرق بين القرين المعلم والقرين المتعلم بين سنة لسنوات عدة.

النمط الثالث: (اندماج الأقران وفق السن في برامج غير رسمية ) وفيه يقوم القرين المعلم

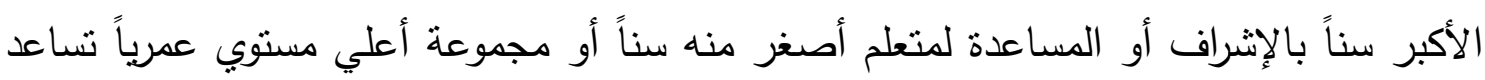

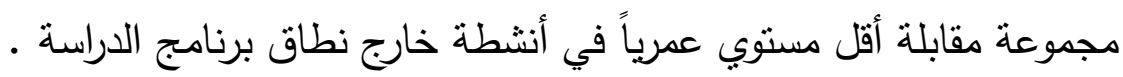

\section{العوامل الموئثرة في تعلم الأقران:}

1. قبول القرين المعلم والأقران المتعلمين بعضهم لبعض، من خلال قيام المعلمة بتهيئة الأطفال لاستخدام استراتيجية تعليم الاقران فتوضح لهم أن هذه الاستراتيجية تستخدم لمساعدة بعضم البعض، حتى يصلوا الي اتقان المادة العلمية أو المهارة المطلوبة. r. مدي توافر المناخ المادي والنفسي من قبل المعلم المشرف علي التدريس بالأقران حتى يمكن للقرين المعلم القيام بمهامه التدريسية. r. التأكيد على تبادل الأدوار بين الأقران المعلمين والأقران المتعلمين، حتى لا يشعر الأقران

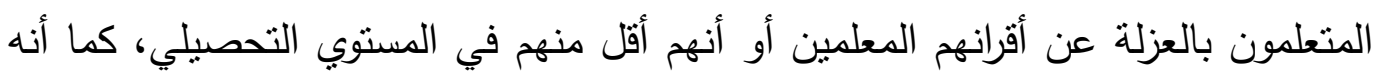
بتبادل الأدوار نزداد فاعلية الأقران المتعلمين. 
ع. جنس الأقران عامل مهم من عوامل نجاح استراتيجية نعليم الأقران، فقد أكدت الدراسات ميل الأقران الي أن يكونوا من نفس الجنس، فذلك يوفر وييسر بدرجة كبيرة عملية التعلم. ه. التعليم المزدوج كلما كان الأطفال في الجلسة في شكل ثنائيات فإن ذلك يعطي نتائج

$$
\text { مرغوباً فيها. }
$$

T. المستوي الاجتماعي والاقتصادي والثقافي، كلما كان منقاربان بين الأقران، فإن ذلك يحقق التعاون والتفاهم والمحبة والتقبل بينهم. V. ضرورة تكرار جلسات تعلم الأقران فكلما زاد عدد الجلسات زادت الفائدة وساعد ذلك على تحقيق الأهداف المرجوة. 1. ضرورة اقتناع أولياء الأمور باستراتيجية تعليم الأقران في تعليم أبنائهم، فذلك عامل مهم من عوامل نجاح الاستراتيجية. 9. اقتناع ادارة المدرسة والمعلمين باستراتيجية تعليم الاقران وذلك لتوفير الامكانيات والمتطلبات اللازمة لنجاح هذه الاستراتيجية. • 1. عمر القرين، فكلما زاد عمر القرين المعلم عن عمر القرين المتعلم أدي ذلك إلي تحسين التعلم بحيث لا يزيد الفرق عن ب سنوات.

1 ا. التدريب فللتدريب فائدة كبيرة لتعليم الأقران لأن تدريب الأقران المعلمين يحسن من فعاليتهم

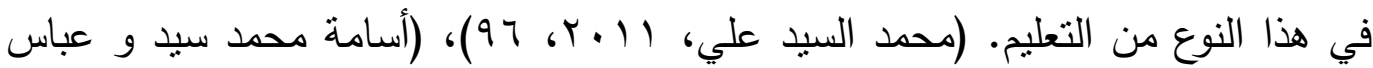

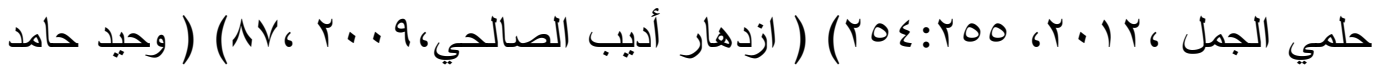

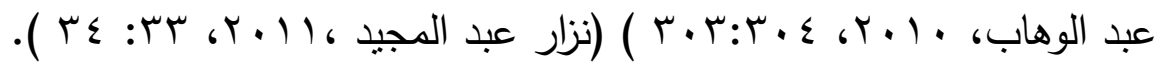
شروط تطبيق تعلم الأقران: 1. كفاية معرفة القرين المعلم الخاصة بموضوع المهارة أو الارس، ويتم ذلك عن طريق عقد لقاءات دورية بين المعلمة وبين الأقُّران المتعلمين تتأكد من خلالها المعلمة من اتقان الأفران المعلمين من المادة العلمية وأنه يمكنهم تعليمها لاقرانهم المتعلمين. 


\section{r. معرفة القرين المعلم لكيفية التفاعل مع عناصر الموقف التدريسي،}

r. القبول من جانب القرين المعلم وأقرانه التلاميذ. وذلك من خلال اعطاء الأقران الحرية لاختيار من يرتاحون إليهم من الأقران المعلمين، بما يحقق لهم التوافق النفسي مع بعضهم

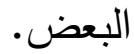

ع. اعداد المعلمة المشرفة لأساليب التقويمية المناسبة لتعرف التغيرات السلوكية المرغوبة لدي كل من القرين المعلم والقرين المتعلم. ه. ضرورة توفير الوسائل التعليمية التي تمكن الأقران المعلمين من أداء دورهم في إكساب أقرانهم المتعلمين المادة العلمية المراد تعلمها. 7. تحضير المعلم المشرف لبيئة التعلم حتى يمكن المعلم القرين بالقيام بواجبه كما هو منوقع منه. r ا.كفاية القرين المعلم من حيث قوة الثخصية وسلامة القيم والأخلاقيات العامة. (ثثاء سعيد حسن أبوزيد وهند على حسين شماخي، 9 1. Y، ع V). (أسامة محمد سيد وعباس حلمي

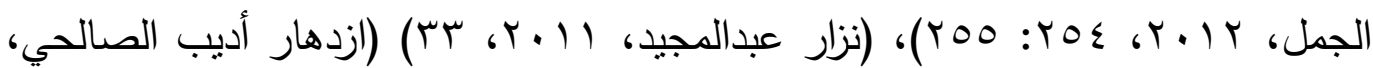
$\cdot(\wedge T, 4 \cdot .9$

\section{خصائص استراتيجية تعلم الأقران:

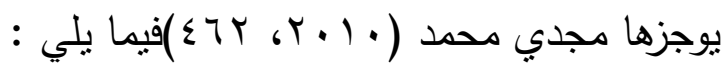

1. تجعل القرين المعلم علي درجة كبيرة من المرونة بحيث بسنطيع الاستمرار في التعليم فيكتسب المعارف والمهارات المختلفة التي يحتاجها في ممارسته لعملية التدريس من حيث تقبل أسئلة أقرانه بصدر رحب والاجابة عليها ، وأن براعي الفروق الفردية بينهم ويثقبل أنثكال النقد البناء r. تحقيق الكثثر من النتائج الايجابية المرغوبة منها تغيير الدور التقليدي للمعلم من مسيطر علي العملية التعليمية باعتباره مصدر للسلطة مما يؤدي لخفض القلق والتوتر لاي المتعلمين ومنحه الفرصة للقيام بالدور الانساني واظهار اهتمامه بالمتعلمين كأفراد وحثهر 
علي بذل الجهد والعمل ومساعدتهم علي مواجهة الصعوبات التي تقابلهم والتغلب علي

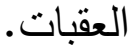

r. تحقيق مبدأ الاعتماد الايجابي المتبادل لأن كل فرد لن يكون مسئول عن عمله فقط بل ومسئول عن عمل غيره في المجموعة حيث يؤنز كل فرد في المجموعة في الأخرين. ء. تفيد في منح المتعلمين وخاصة الذين يفتقدون ثقتهم بأنفسهم ، فتتمي لديهم القناعة بأنهم يستطيعون التعلم متل القرين المعلم ، بل وتتجيعهم علي أنهم يسنطيعون القيام بنفس دور،

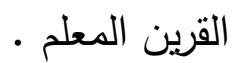
ه. تتيح الفرصة للقرين المعلم في التدريب علي مهارة تدريسيةمددة في فترة زمنية قصيرة مع اتاحة الفرصة للحصول علي تغذية راجعة فورية ، مما بعني أن التلميذ ينلقي تقويماً وتدعيماً أكثر هذا بالضافة لتكرار دورة التعلم أكثر من مرة حتي يتقن المهارة التنريسية.

\section{عيوب استراتيجية تعلم الأقران:}

علي الرغم من المميزات والمحاسن الكثيرة لاستراتيجية تعلم الاقران إلا أن بعض المختصين يوجهون بعض التحفظات والانتقادات لتلك الاستراتيجية ويمكن توضيحها فيما يلي: 1. الوقت المستهلك لتدريب الأقران يكون على حساب تدريس المحتوي. r. بعض المجموعات ليس لديها المهارات التعاونية الملائمة للعمل بشكل فعال وليس لديها الخبرة في عملية التعلم، فالأطفال يختلفون في القدرات والمستويات وبالتالي في المتابعة والتقويم. r. صعوبة تقييم الأقران لبعضهم البعض لأن الأقران يقيمون بعضهم البعض بأعلى الدرجات حتى لا يستهان بهم في العملية التعليمية. ع ـ زيادة مسئولية الطفل وزيادة العمل المحدد له. ه. الاستراتيجيات التي يستخدها المعلمون لتدريب الأقران مازالت غير كافية وغير منطورة للتنريب. 7. ال ا توجد مناهج تجارية متاحة ومتوفرة لتدريب الأقران. V. قد يقوم القرين المعلم بالتسلط والسيطرة على القرين المتعلم تقليدا للمعلم الذي قد يمتل نموذجا للتسلط والسيطرة أحياناً. 
^.قد يعترض أولياء أمور المتعلمين على استخدام أسلوب تعلم الأقران؛ فعملية التدريس بالنسبة لهم تسير حول الاعتقاد التقليدي بأن الانتقال الأفضل لكل أنواع التعليم يكون من الكبير إلي الصغير مخطط لها مسبقا.

9. التكلفة العالية لتدريب الأقران والتي نتنتل على تخطيط الوقت وتدريب المعلمين وتدريب مجموعات الأقران، فهي تتطلب موارد متعددة من أموال ومهارات وزمن لاختبار مدربي الأقران (الطلاب المعلمين) وتدريبهم وادارة شئون تعليمه أثناء عملية تعلم الاقران.

• 1. في الفصول (القاعات) المزدحمة بالمتعلمين تكون الضوضاء مرتفعة بصورة تتشت انتباه المتعلمين.

11 ا. من الصعب توفير جو من الألفة والصداقة لعدد كبير من المتعلمين داخل حجرة الدراسة. r ا. يميل أسلوب تدريب الأقران إلى التركيز على تعزيز النوعية بدلا من تغيير السلوك. rا. . قد يتم توريط القرين المعلم للقيام بهذا الدور دون رغبته في ذلك. ـ ا. نقص خبرة القرين المعلم للموضوعات أو المهام المكلف بندريسها لأقرانه. 1 ا. قد توثر المشكلات السلوكية للأقران المعلمين على طبيعة الموقف التعليمي وعلى أقرانهم. 17. عدم قدرة القرين المعلم أحياناً على السبطرة على أقرانه المتعلمين مما يسبب حدوث ضوضاء داخل الفصل (القاعة).

V V ا. مقاومة العديد من أطراف العملية التعليمية لنطبيق الاستراتيجية (المعلم _ مديري المدارس _

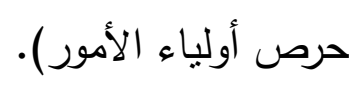

1 1. قد يصعب حدوث التعلم بواسطة الاقران إذا لم يعد المعلم المواد التعليمية والاجراءات الخاصة بتعليمها بإحكام قبل بدء التعليم.

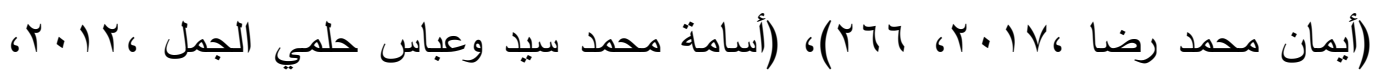

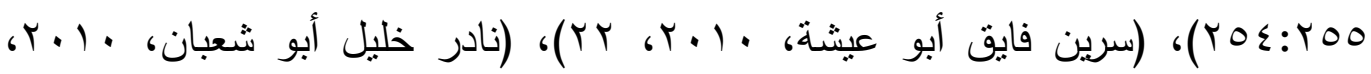

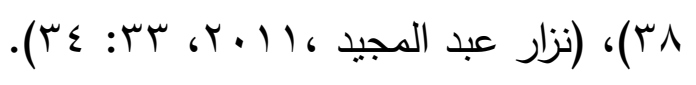




\section{دور المعلم في استراتيجية تعلم الأقران:}

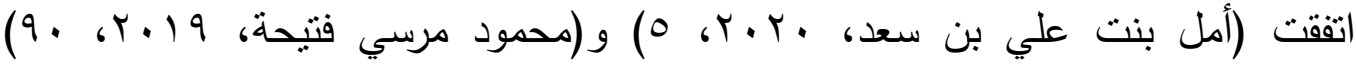

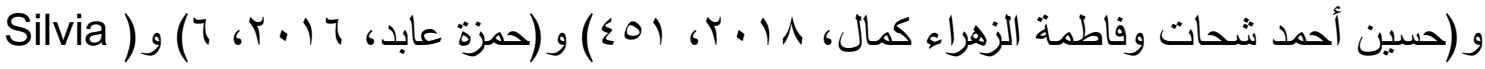
( ‘Blanch, David Duran, Vanessa Valdebenito \&Marta Flore ,2012, 2) .Yusuf Abdulrahim, Hamdallat T. Yusuf, Adesegun O. Odutayo, 2017, 99

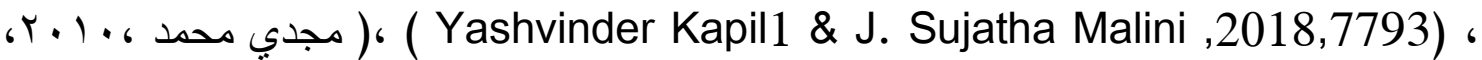

علي أن دور المعلم تغير من مجرد ناقل للمعرفة إلي ميسر ومصمم لعملية وبيئة التعلم ومشخص للطلبة ومرشد ومتابع وموجه ومعين وقت الحاجة فهو يقوم بتحضير الأدوات والوسائل اللزمة لعملية التدريب مع تخصيص الزمن اللازم لكل نشاط والمكان المناسب لتطبيقه، كما يعمل علي تحديد الأهداف التي يسير علي أساسها العمل، و تحديد طريقة تعامل الطلبة وطرق استخدام التعزيز المناسبة في المواقف التعليمية المختلفة حيث يبقي منابعا لسير النشاط في الدروس المختلفة مع مراعاة عدم التدخل إلا في الأوقات التي تتطلب تدخل إيجابي منه وذلك لتصحيح مسار نشاط أو تغيير الأداة أثثاء الدرس أو النشاط حتي تتحقق النتاجات المطلوبة. كذلك يعفي تدريس الأقران المعلم من كثير من الأعمالهما يتيح له وقتاً كافيا لأداء دوره الانساني الذي يتمثل في لااظهار الاهتمام بالمتعلمين كأفراد وحثهم علي بذل الجهد والعمل ، ومساعدتهم علي مواجهة الصعوبات التي تقابلهم والتغلب علي ما يعترضهم من عقبات. كما أصبح المتعلم المحور الذي تبني حوله جميع الأنشطة والتفاعلات، فامتلك بذلك دوراً نشطاً، جعل من أبرز مهامه البحث والاستكثاف والتجريب وتحمل مسئولية التعلم، وهي مهام تتطلب قدراً من المهارات لاتقانها. لتحقيق الهدف المنشود. 
ثالثاً - الجانب الميداني للبحث:

أدوات البمث: تتمثل أدوات البحث الحالي فيما يلي: -

أولاً : المواد التعليمية (مادة المعالجة التجريبية):

أ. البرنامج المقترح باستخدام استراتيجية تعلم الأفران في تنمية الوعي المائي للدي

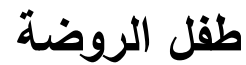

تم إعداد البرنامج التعليمي باستخدام استراتيجية تعلم الأقران في تتمية الوعي المائي لدي طفل الروضة، وذللك في ضوء خصائص طفل الروضة والدراسات السابقة والبحوث المتعلقة بموضوعات

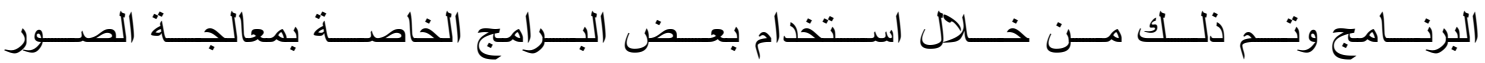
Adobephotoshop الفيديو Adobe premier واستطلاع رأي المكمين حول القضايا المائية التي تخص الوعي المائي المتضمنة للبرنامج والتي تتتاسب مع طفل الروضة. الأهداف العامة والأهداف السلوكية (التعليمية) للبرنامج:

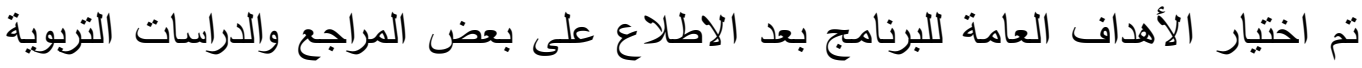

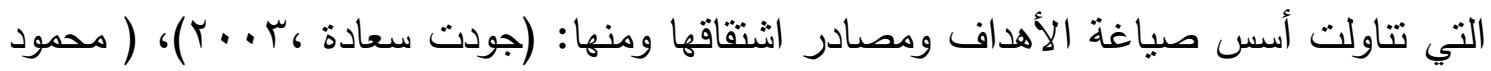

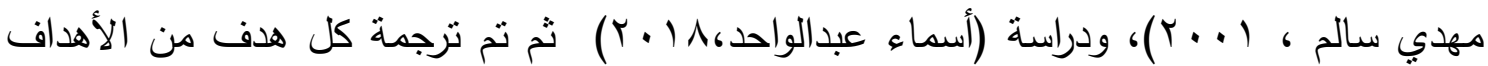

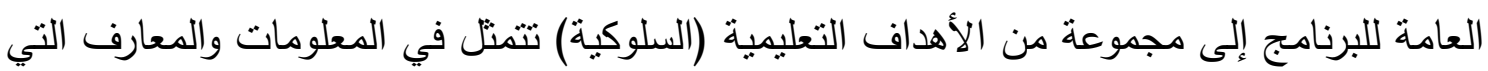
يتم تزويد الطفل بها من خلا الأنشطة المختلفة و العروض التقديمية ، وتم عرض هذه الأهداف

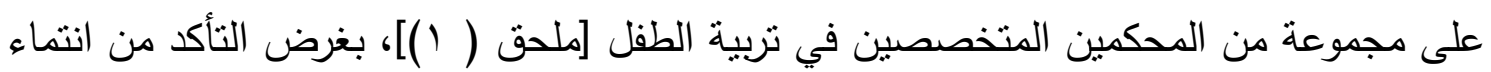
الأهداف التعليمية للهدف العام، وأثنارت آراء المحكمين إلى انتماء الأهداف التعليمية للهدف العام ، وفيما يلى عرض للهدف العام والأهداف التعليمية في صورتها النهائية. " اهتمام الطفل بالمحافظة على الماء ". ف في نهاية البرنامج يصبح الطفل قادراً على أن: ا ـ يتعرف الطرق المختلفة لترشيد استهلالك المياه. r. ب. بتعرف المصادر المختلفة لنلوث المياه. r. ب ب بتنتج أهمية المحافظة على المياه وترشيد استهلاكها.

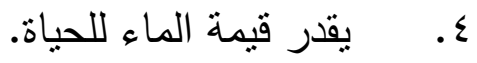




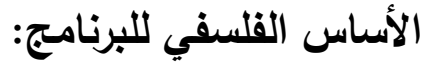

تتبثق فلسفة البرنامج من الضرورة الملحة لتتمية الوعي المائي لدي طفل الروضة ومن

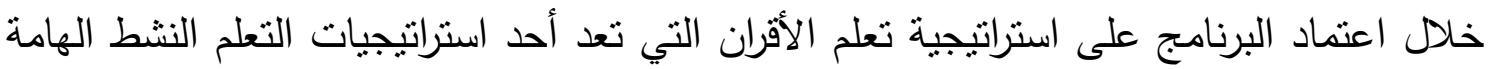
والتي تجعل الطفل محور العملية التعليمية، وتزيد من إيجابية المعلم والمتعلم وتجعل عملية التعلم

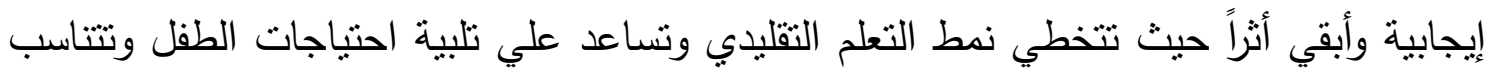
معهه وتجعل من المعلم محفز وميسر وموجه مما يساعد علي نوفير تعلم نشطاً ايجابياً. تحديد محتوى البرنامج المقترح: تعد عملية اختيار البرنامج هي احدى الخطوات الهامة لبناء البرنامج ويتمنل ذلك في

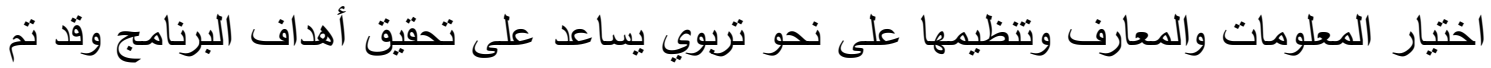

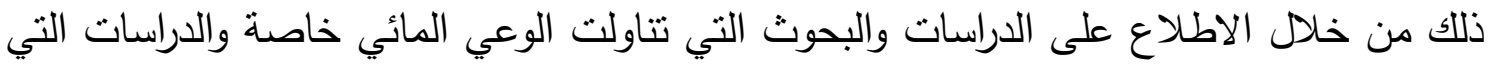

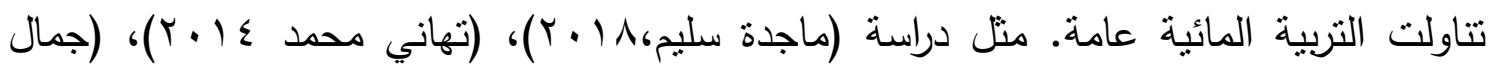

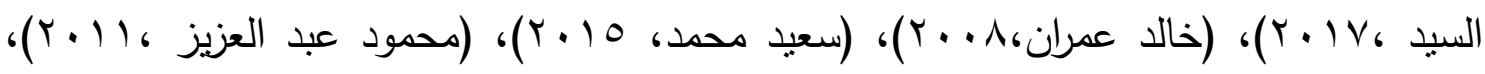

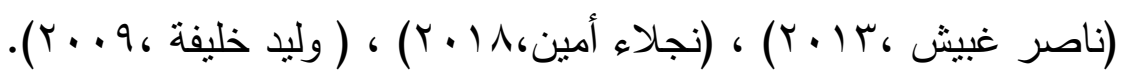
وقد تم تحديد محتوى البرنامج وفقاً للمعايير التالية:

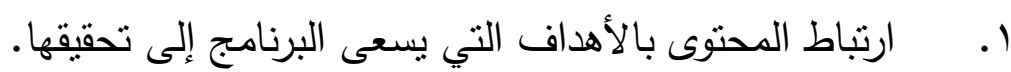
r r ملائمة المحتوى لخصائص وخبرات وحاجات طفل الروضة. r. دقة المحتوى وسلامته العلمية.

وقد تم تحديد المحتوى بحيث تضمن .: قضايا المياه المرتبطة بالوعي المائي ويتمثل محتواه فيما الطرق المختلفة لترشيد استهلاك المياه. المصادر المختلفة لتلوث المياه.

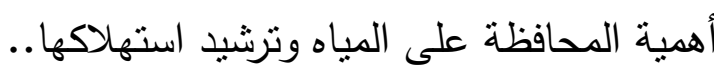
تنظيم وعرض المحتوى: ق قلميمة الماء للحياة. تم ترجمـة هذا المحتوى إلى أنشطة مختلفة تتمثل في صور ثابتة تعرض منفردة أو من خـلال برنامج Power point)، وقصص تخدم بعض الجزئيات داخل المحتوى، وكذللك بعض الأغاني تُوني

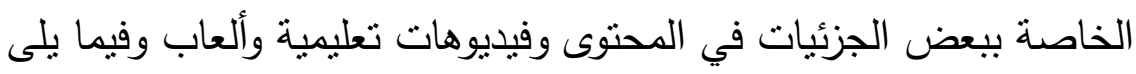
بطاقات مصورة للاستخدام الجيد للمياه. بطاقات مصورة للاستخدام السيء للمياه. 


$$
\begin{aligned}
& \text { فيديو يوضح الاستخدام السيء للمياه. } \\
& \text { بطاقة لعلامة (ل ) وبطاقة لعلامة (X). } \\
& \text { بطاقات مصورة توضح بعض مصادر تلوث المياه. } \\
& \text { فيديو لقصة عن تلوث المياه. (قصة أحمد والسمكة اخلاص). }
\end{aligned}
$$

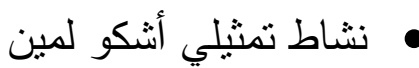

$$
\begin{aligned}
& \text { كوبين من الماء. } \\
& \text { قليل من الاتربة. }
\end{aligned}
$$

الأنشطة التعليمية:

تضمن البرنامج نوعان من الأنشطة، نوع يقوم به القائم على التطبيق مع الطفل القرين المعلم ونوع يقوم به الطفل القرين المتعلم مع الأطفال أنفسهم لتحقيق أهداف البرنامج وهما كما

1. الأنشطة التي يقوم به القائم على تطبيق البرنامج:

تقسيم الأطفال إلى مجموعات صغيرة كل مجموعة تتكون من ثمانية أطفال.

يتم التمهيد للطفل القرين المعلم عن كل بعد من الابعاد الخاصة بالبرنامج وشرح الأنشطة له ليقوم بدوره في شرح الأنشطة لزملائه تحت اشراف وتوجيه المعلمة. r. تنفيذ البرنامج مع الأطفال من خلال الطقل القرين المعلم:

يقوم الطفل القرين بتتفيذ الأنشطة مع زملائه كما نفذتها معه المعلمة، مع مراعاة أن يكون ذلك تحت اثراف وتوجيه معلمته، وذلك تجنبا لحدوث أي خطا من الطفل القرين المعلم، وتقديم المساعدة له في حال تعثره في شيء، مع اتاحتها الفرصة لهم لطرح تساؤلاتهم وتعليقاتهم وتفاعلهم مع الطفل القرين المعلم، ويتم تكرار ذللك مع كل بعد من أبعاد البرنامج. 


\section{بعد تنفيذ البرنامج:}

يتم تقييم الأنشطة التي تم تتفيذها من خلال الطفل القرين المعلم من قبل المعلمة، وذلك للتأكد من معرفة الأطفال وفههم لكل بعد من أبعاد البرنامج، كما تترك لهم المعلمة الفرصة للممارسة الأنشطة، والألعاب، وغناء الأغاني والاناشيد التي تتاولها البرنامج.

r. وبذلك يكون قد تم الإجابـة عن التساؤل الأول من تسـاؤلات البحث والذي ينص على " ما مكونات البرنامج المقترح لتتمية الوعي المائي باستخدام استراتيجية تعلم الأقران

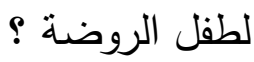

تقويم البرنامـج:

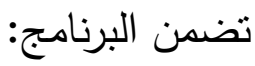
تقويم قبلي:

وذلك باستخدام مقياس الوعي المائي المصور لأطفال الروضة.

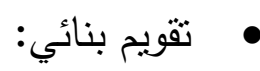

مستمر خلال فترة عرض البرنامج بغرض التأكد من انتباه الأطفال وإدراكهم وفهمه لمحتوى

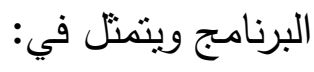

ا. بطاقات تصنيف الصور الخاصة بمحتوي البرنامج بهدف التأكد من فهم ومعرفة الأطفال للمحتوي.

r. سؤال الأطفال عما يشاهدونه في أثثاء عرض الأنشطة المختلفة ومدى استيعابهم لها تفصيل البرنامج في [ملحق (r)].

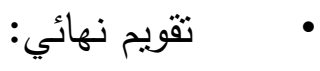
يعقب تطبيق البرنامج ويتم من خلال الآتي:

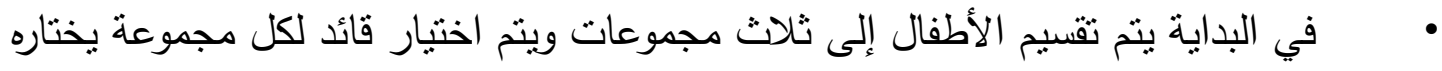
الأطفال أنفسهم ليجيب عن الأسئلة الجماعية أما الأسئلة الفردية فيجيب كل طفل عنها بمفرده عند توجيه السؤال له. 


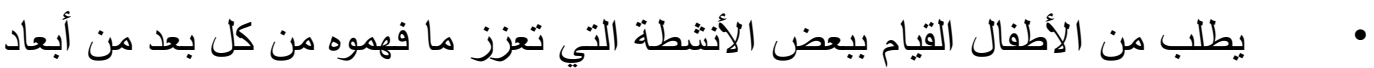

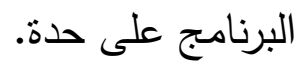

ب. دليل المعلمة لتطبيق برنامج مقترح لتنمية الوعي المائي باستخدام استراتيجية تعلم الأقران لطقل الروضة.

تم إعداد دليل إرشادي لمعلمات رياض الأطفال لتطبيق برنامج مقترح لتتمية الوعي المائي باستخدام استراتيجية تعلم الأقران لطفل الروضة. وتتاول الدليل ما يلي:

$$
\begin{aligned}
& \text { 1. إشادات عامة. }
\end{aligned}
$$

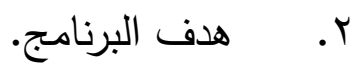

$$
\begin{aligned}
& \text { • ب الفئة المستهدفة. } \\
& \text { ع. }
\end{aligned}
$$

ه. المهارات المنطلب توافرها للتعامل مع البرنامج.

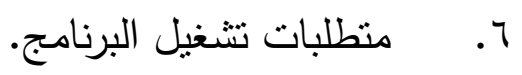

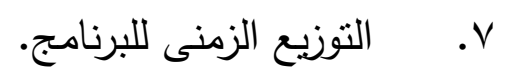

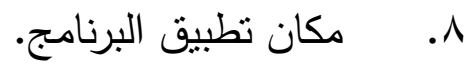

9. دور المعلمة القائمة على التطبيق.

• . . دور الطفل القرين المعلم.

ا'. دور الأطفال القرناء. وتفصيل ذلك في [ملحق (ع)].

مقياس الوعي المائي:

ا ـ إ: وصف المقياس:

هو عبارة عن مقياس شخصي مصور لقياس الوعي المائي لدي أطفال الروضة لكل من قضايا المياه الآتية (ترشيد المياه - اسراف المياه - تلوث المياه)، وقد تم تصميم 
هذا المقياس لمساعدة المهتمين بمجال تربية الطفل في إمكانية قياس الوعي المائي لأطفال الروضة.

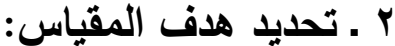

قياس مدي فعالية استراتيجية تعليم الأقران في تتمية الوعي المائي لاي أطفال الروضة.

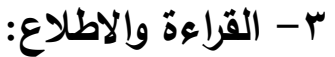

بعد إعداد البرنامج المقتزح لتتمية الوعي المائي لدي طفل الروضة جاءت خطوة اعداد

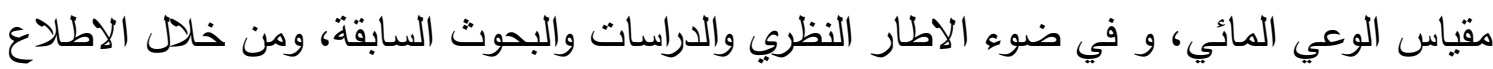

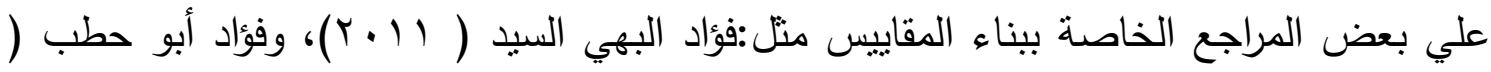

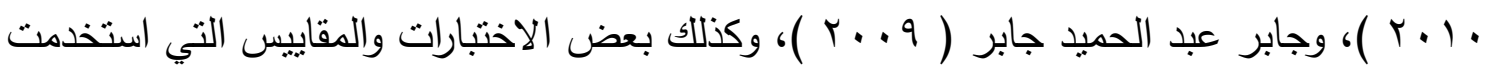

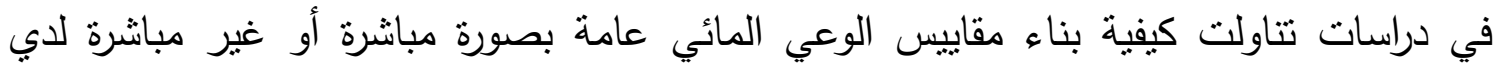

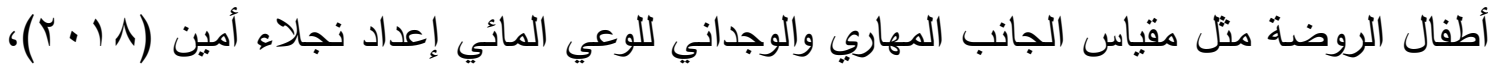

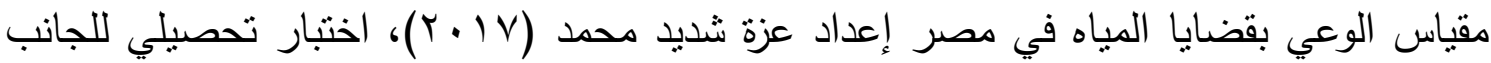

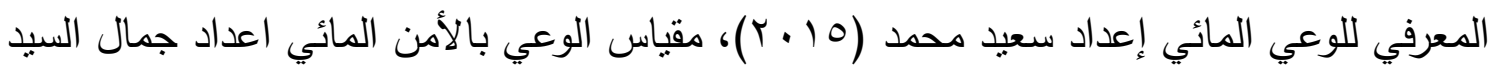

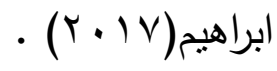

\section{ـ ـ صياغة أسئلة المقياس وتحديد نوع الأسئلة:}

تم إعداد الدقياس في ضوء الاطار النظري والدراسات والبحوث السابقة والصورة النهائية لقائمة المفاهيم المائية، وتمت صياغة عبارات المقياس في صورة أسئلة اختيار من متعدد مقتصراً

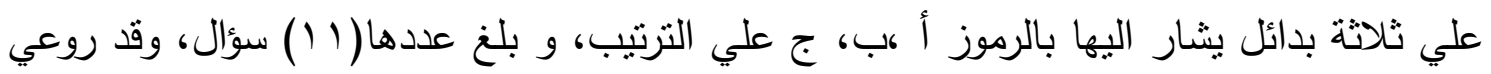

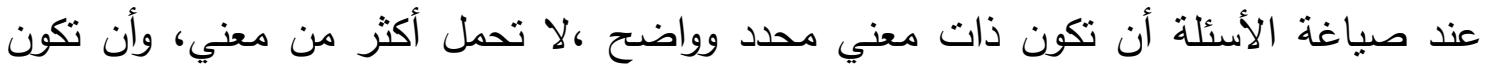

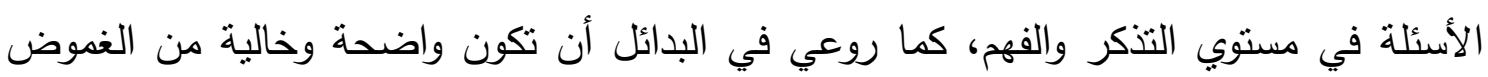

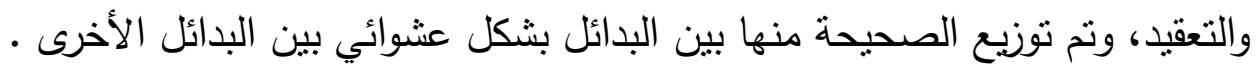

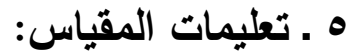

تم وضع تعليمات واضحة حيث يترنب عليها وضوح الهدف من المقياس، وكيفية أدائه

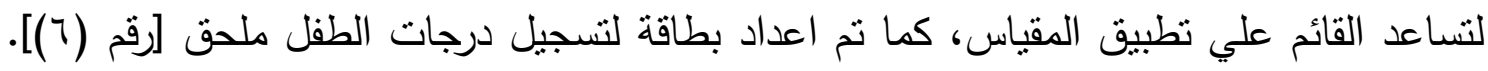
وبطبق المقياس فردياً على الأطفال. 
7 ـ الصورة المبائية للمقياس:

تم عرض المقياس في صورته الأولية على مجموعة من المكمين عددهم (V) سبعة محكمين ملحق [رقم (0)]. لإبداء الرأي في الاتي:

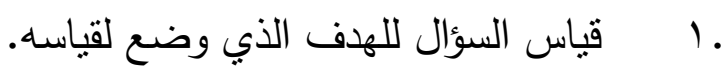
r. مناسبة مستوي السؤال لطفل الروضة.

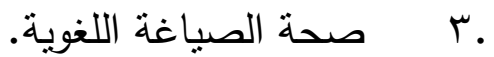

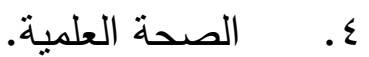

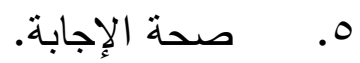
1. احلاحية المقياس للنطبيق.

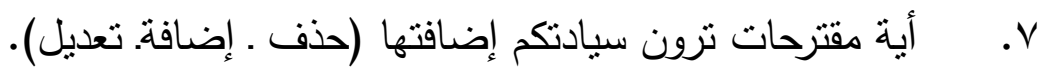

وقد أثنارت آراء المحكمين إلي قياس السؤال للهدف الذي وضع لقياسه، مناسبة مستوي السؤال لطفل الروضة، وصحة الصياغة اللغوية، والصحة العلمية، و صحة الاجابة لدفردات المقياس، واقترحوا بعض الصياغات اللغوية في بعض الأسئلة كما يوضح الجدول التالي: 
جدول ( ) تعديلات الصياغة اللغوية لبعض عبارات مقياس الوعي المائي لطفل الروضة.

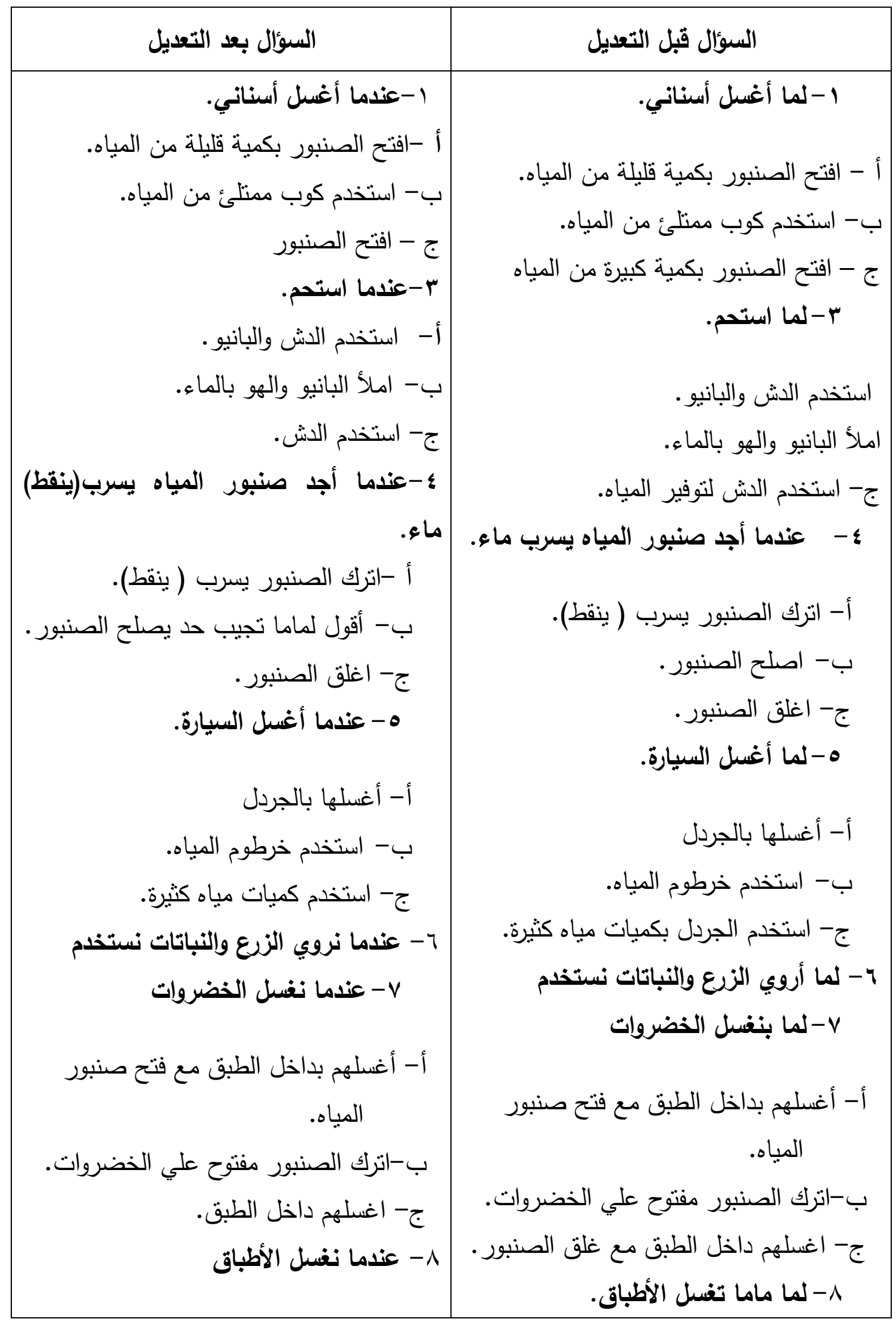


V

يعطى الطفل درجة واحدة في حالة الإجابة الصحيحة، وصفر في حالة الإجابة الخاطئة،

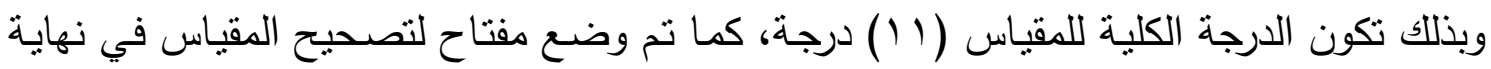

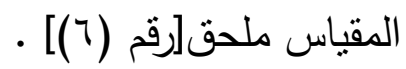
1 ـ ت تحليل مفردات المقياس:

قامت الباحثة بإجراء دراسة استطلاعية للتعرف على مناسبة المقياس للتطبيق على مجتمع البحث وذلك عن طريق تطبيقه على عينة عشوائية قوامها (7 ( ) طفل من مجتمع البحث ومن غير العينة الأصلية وتهدف الدراسة إلى ما يلي: ـ التعرف على مدى مناسبة صياغة الأسئلة لعينة البحث. ـ التعرف على مدى فهم أفراد العينة لتعليمات المقياس. . حساب معامل السهولة والصعوبة والتمييز لأسئلة المقياس.

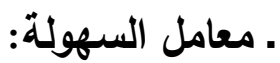
تم حساب معامل السهولة لأسئلة المقياس باستخدام المعادلة التالية: الإجابات الصحيحة للسؤال

الإجابات الصحيحة + الإجابات الخاطئة

م معامل الصعوية:

نظراً لان العلاقة بين السهولة والصعوبة علاقة عكسية مباشرة فان مجموعهما يساوى (1)

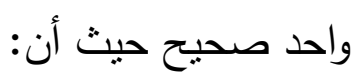
معامل السهولة = 1 ـ معامل الصعوبة. معامل الصعوبة = 1 ـ معامل السهولة 
لحساب تمييز أسئلة المقياس استخدمت الباحثة المعادلة التالية: معامل التمبيز = معامل السهولة × معامل الصعوبة.

وبنـاء على مـا سـبق يوضـح جدول (Y) معـاملات السـهولة والصـعوبة والتمبيز لأسـئلة - المقياس
جدول (r) - (ץ)

معامل السهولة والصعوية والتمييز لأسئلة المقياس (ن = 14 )

\begin{tabular}{|c|c|c|c|c|c|c|c|}
\hline معامل & معامل & معامل & p & التمبيز & معامل & معامل & م \\
\hline . ro &..$\leqslant \leqslant$ & .07 & V & . ro &..$\leqslant \leqslant$ & .07 & 1 \\
\hline . ro & .07 &..$\leqslant \Sigma$ & $\wedge$ & . ro & .0 & .0 & r \\
\hline . TO & .0 & .0 & 9 & . ro &..$\leqslant \varepsilon$ & .07 & r \\
\hline . TO & .07 &..$\leqslant \leqslant$ & 1. & . YO &..$\leqslant \varepsilon$ & .07 & $\varepsilon$ \\
\hline \multirow[t]{2}{*}{. TO } &..$\leqslant \leqslant$ & .07 & 11 & . YO & .07 &..$\leqslant \leqslant$ & 0 \\
\hline & & & & .ro & .07 &..$\leqslant \leqslant$ & 7 \\
\hline
\end{tabular}

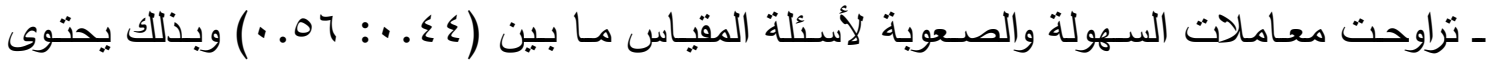
المقياس على أسئلة منتوعـة من حيث السـهولة والصـوبة لتتناسب مـع المستويات المختلفة مـن الأطفـال، كمـا يتضـح أن المقيـاس ذو قوة تمييـز مناسـبة إذ بــغ معامـل التمييز لأسـئلة المقيـاس (0. . • ) وبهذا يكون المقياس صالحاً كأداة معرفية . 9 ـ تحديد الزمن اللازم للمقياس: لحساب زمن المقياس استخدمت الباحثة المعادلة الرياضية التالية: 


\section{الزمن الذي استغرقه أول طفل + الزمن الذى استغرقه أخر طفل}

وبذلك تمكن الباحث من تحديد زمن المقياس وكان (10) دقيقة مع عدم احتساب الوقت

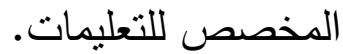

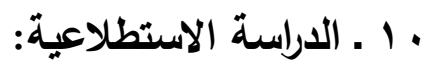

قامت الباحثة بإجراء دراسة استطلاعبة للتعرف على مدي مناسبة المقياس للتطبيق على مجتمع الدراسة وذلك عن طريق تطبيقه على عينة عشوائية قوامها (7 (1) طفل من مجتمع الدراسة

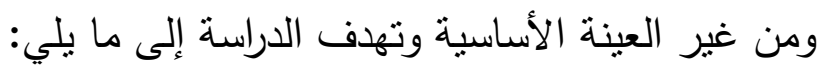
ـ التعرف على مدى مناسبة صياغة الأسئلة لعينة الدراسة. . التعرف على مدى فهم أفراد العينة لتعليمات الدقياس. • (إيجاد المعاملات العلمية من صدق وثبات.

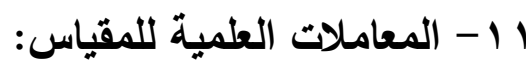

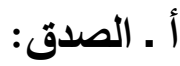

لحساب صدق المقياس استخدمت الباحثة الطرق التالية:

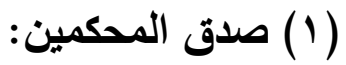

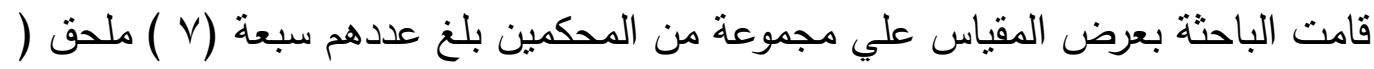

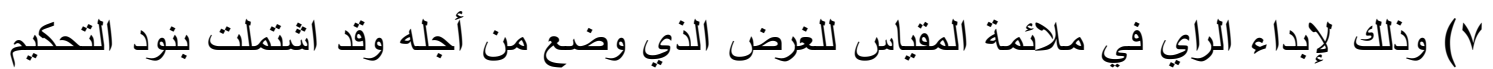
علي ما يلي: - n

قياس السؤال للهدف الذي وضع لقياسه.

مناسبة مستوي السؤال لطفل الروضة.

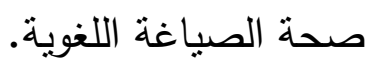

الصحة العلمبة. 


\section{صحة الاجابة.}

صلاحية الاختبار للنطبيق.

أية مقترحات ثرون سيادتكم إضافتها (حذف ـ إضافة. تعديل).

وقد استتدت الباحثة لنسبة ، ٪\% فأكثر من آراء المحكمين، وبناء على ذلك تم موافقة المحكمين على جميع الأسئلة وكذلك تعديل صياغة بعض الأسئلة وكذلك تعديل وتغيير بعض الصور وجاءت مقترحات المحكمين لتعديل صياغة بعض الأسئلة كما هو وارد بجدول رقم (1)

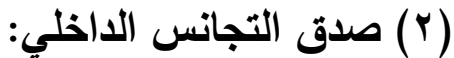

لحساب صدق التجانس الداخلي للمقياس قامت الباحثة بتطبيقه على عينة قوامها (1 ( ) طفل من مجتمع الدراسة ومن غير العينة الأساسية للدراسة، وقد تم حساب معاملات الارتباط بين درجة كل سؤال من أسئلة المقياس والدرجة الكلية للمقياس، والجدول (ب) توضح النتيجة.

$$
\text { جدول (r) }
$$

معاملات الارتباط بين درجة كل سؤال من أسئلة المقياس

$$
\text { والارجة الكلية للمقياس (ن = } 17 \text { ) }
$$

\begin{tabular}{|c|c|c|c|}
\hline معامل الارتباط & رقم السؤال & معامل الارتباط & رقم السؤال \\
\hline$* * \ldots Y Y$ & v & $* * .70$ & 1 \\
\hline$* * .70$ & $\wedge$ & $* * \ldots r$ & r \\
\hline$* .07$ & 9 & $* * \ldots r$ & r \\
\hline$* * .70$ & 1. & $* * . V r$ & $\varepsilon$ \\
\hline \multirow[t]{2}{*}{$* * .71$} & 11 & $* * . .79$ & 0 \\
\hline & & $* * . .79$ & 7 \\
\hline
\end{tabular}




$$
\begin{aligned}
& \text { ** * دال عند مستوي (1 (•) } \\
& \text { * دال عند مستوي (0...) } \\
& \text { يتضح من جدول (ب) ما يلي: }
\end{aligned}
$$

ـ تراوحت معاملات الارتباط بين درجة كل سؤال من أسئلة المقياس والدرجة الكلية للمقياس ما بين (ד ه . : r. . . . ) وهي معاملات ارتباط دالة إحصائياً مما يشير إلى التجانس الداخلي للمقياس. ب ـ الثبات: لحساب ثبات المقياس استخدمت الباحثة ما يلي:

(1) التطبيق وإعادة التطبيق:

لحساب ثبات المقياس استخدمت الباحثة طريقة النطبيق وإعادة التطبيق وذللك عن طريق تطبيق المقياس على عينة قوامها (7 (1) طفل، ثم تم إعادة تطبيق المقياس على نفس العينة بفارق زمني قدرة (0) يوم بين التطبيقين، ثم تم حساب معامل الارتباط بين التطبيقين، وقد بلغ معامل الارتباط للمقياس (ب9 . •)، وهو معامل دال إحصائياً مما يثير إلى ثبات المقياس.

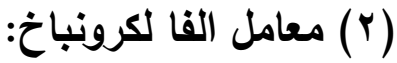

لحساب ثبات المقياس استخدمت الباحثة معامل الفا لكرونباخ، حيث قامت الباحثة بتطبيق المقياس على عينة من مجتمع البحث ومن غير العينة الأصلية للبحث قوامها (7 ( ) طفل، وقد بلغ معامل الفا للمقياس (1N. • )، وهو معامل دال إحصائياً مما يشير إلى ثبات المقياس . r ا ـ الصورة النهائية للمقياس:

تكون المقياس في صورته النهائية من عدد (11) مفردة تقيس بعض القضايا المائية المتمنلة في (ترشيد المياه - اسراف المياه - تلوث المياه) من خلال مستوي التذكر والفهم ملحق [رقم (؟)]

المعالجات الإحصائية المستخدمة : تم استخدام المعاملات الإحصائية التالية :

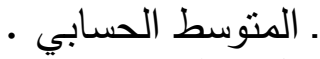
. الوسيط . • م الانحراف المعياري .

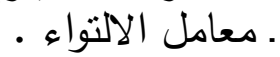
. النسبة المئوية . معائة . . معامل الارتباط المئ. 
. معامل السهولة .

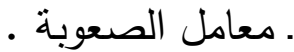

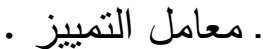

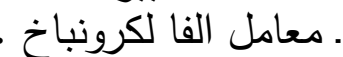

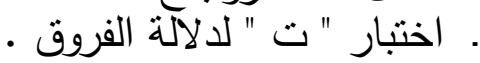

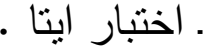

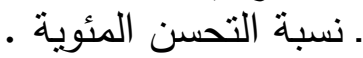

وقد ارتضت الباحثة مستوى دلالة عند مستوبى (0 ... ، 1 . . .) ، كما استخدمت الباحثة

برنامج Spss لحساب بعض المعاملات الإحصائية .

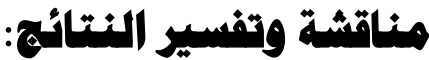

من خلال من سبث يتم عرض النتائج كالتالي:

الفرض الأول : بنص الفرض الأول على أنه :

يوجد فرق دال إحصائياً بين متوسطي درجات المجموعة التجريبية في التطبيقين

القبلي والبعدي علي مقياس الوعي المائي لصالح التطبيق البعدي .

وللتحقق من صحة هذا الفرض تم إيجاد المتوسط الحسابى للقياسيين القبلى والبعدى للمجموعة التجربيية، ومتوسط الفروق بين المتوسطين، والإنحراف المعيارى للفروق وإيجاد قيمة (ت)، وإيجاد قوة التأثثر التى حدثت لدرجات أفراد المجموعة التجريبية فى القياسيين القبلى والبعدى كما هو موضح فى الجدول التالى: والجالى

\section{جدول (๕)}

دلالة الفروق بين متوسطي التطبيقين القبلي والبعدى للمجموعة التجريبية في الوعي المائي

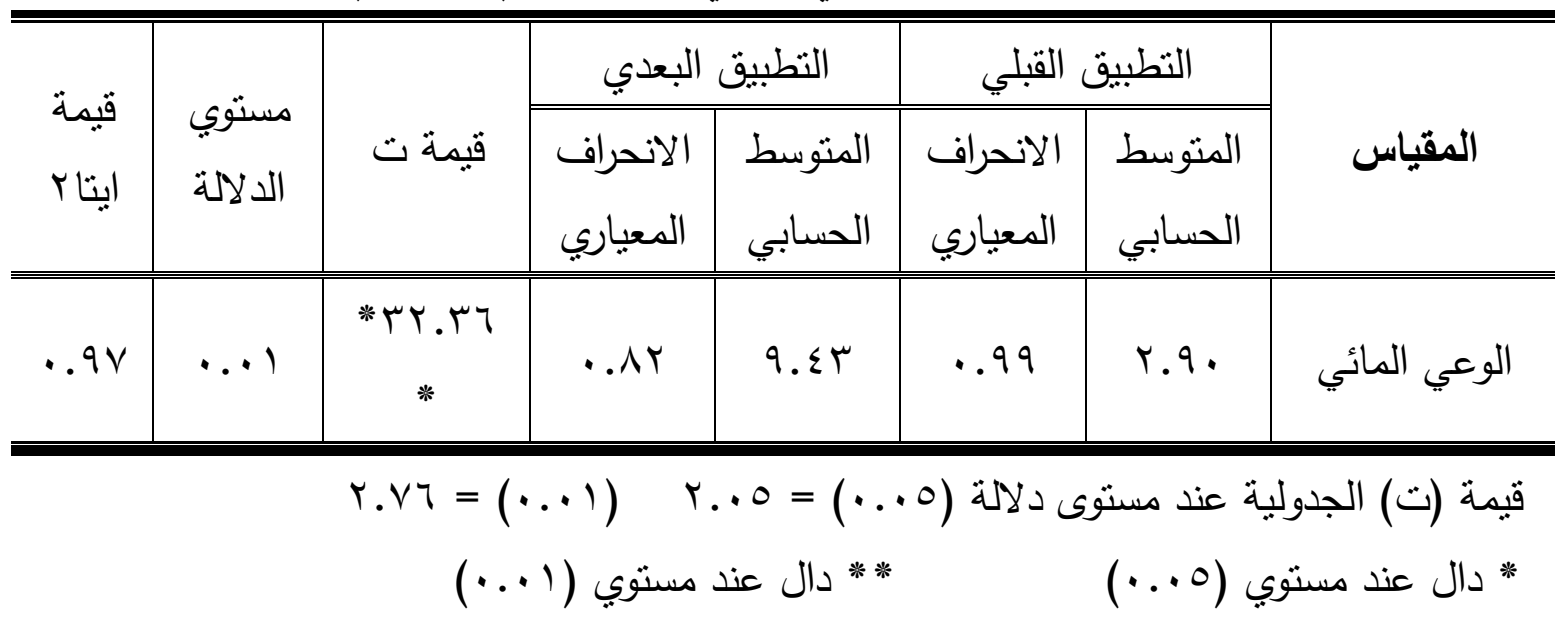




$$
\text { يتضح من جدول (ع) ما يلي : }
$$

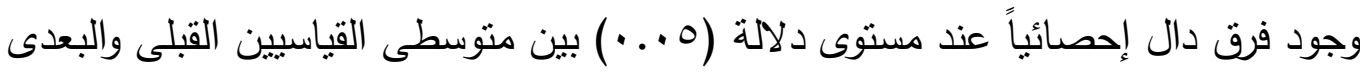

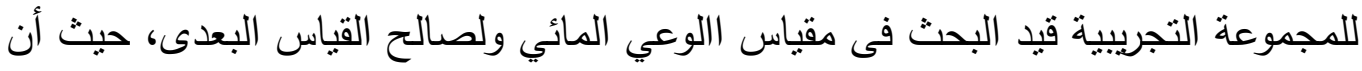

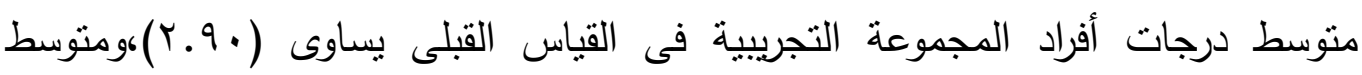

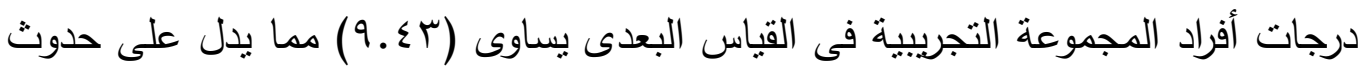

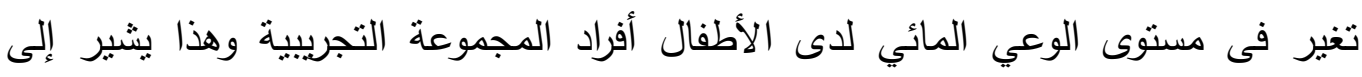
فعالية البرنامج المقترح بإستخدام استراتيجية تعلم الأقران.

ولعل من أسباب هذا التغيز:

تحديد ووضوح الأهداف التعليمية للبرنامج المقترح باستخدام استراتيجية تعلم الاقران في تتمية الوعي المائي، وصياغتها في صورة اجرائية محددة ساعد على تحقيقها.

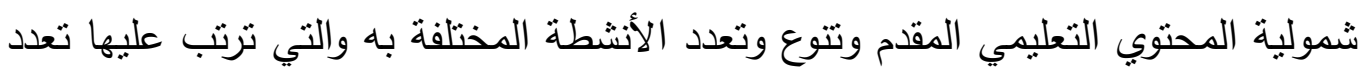

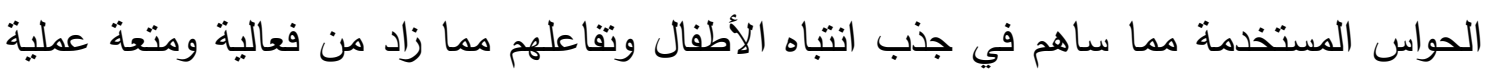
التعلم وجعلها أبقي أثراً. مناسبة البرنامج للعمر العقلي والزمني لأطفال مرحلة الروضة وملائمته لخصائص النمو المختلفة وطبيعة الأطفال في نتلك المرحلة . عرض المعلومات والمعارف والمفاهيم والسلوكيات التي تخص الوعي المائي بطرق جذابة وممتعة وبوسائل مختلفة ومتتوعة ساعدت في جذب انتباه الاطفال وجعلت من عملية التعلم ابقي اثراً لديهم. ومعنة وبونا

طبيعة استراتيجية تعلم الأفران التي جعلت من المتعلم سواء القرين المعلم أو القرين المتعلم محور العطلية التعليمية. دور المعلمة والذي كان ميسراً ومحفزاً لعملية التعلم علي حد سواء مع القرين المعلم والقرين المتعلم وأساليب تعزيزها لهم ساهم ذلك في زيادة فعالية عملية التعلم والتعاون بين القرين المعلم والقرين المتعلم.

دور المعلمة كميسر ومحفز في هذه الاستراتيجية أعطي لها فرصة في القيام بعملية المتابعة وتقييم عمل القرين المعلم والمتعلم.

وجود قوة تأثير قوية للبرنامج المقترح علي تحسين الوعي المائي لدي أطفال المجموعة

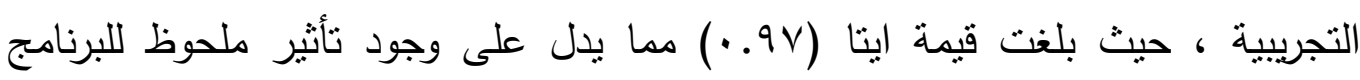

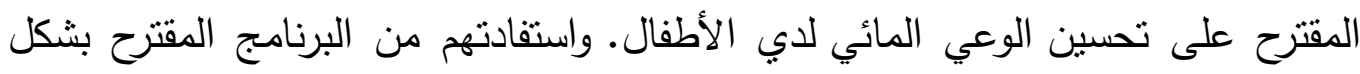

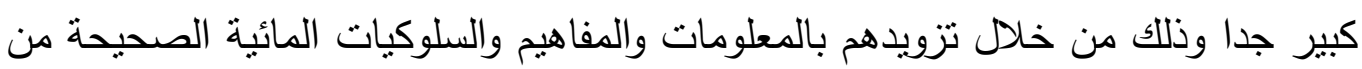


خلا الانشطة المختلفة بالبرنامج باستخدام استراتيجية تعلم الاقران والتي تتاولت أهمية المياه وكيفية المحافظة عليها وطرق ترشيد المياه وتلوث المياه وأسبابه، وكيفية المحافظة

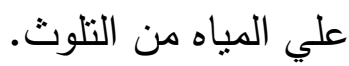

• وترجع الباحثة السبب في وجود قوة التأثير للبرنامج المقترح باستخدام استراتيجية تعلم

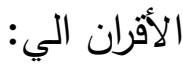

ما أحدثثه استراتيجية تعلم الاقران من تتاغم و وتفاعل بين القرين المعلم والقرين المتعلم وفعلت من عملية التعلم بينهم حيث أضفت علي العلاقة بينهم مرونة وسلاسة وتلقائية لا تتوافر بين الطفل والمعلمة، فعلاقة الطفل بمعلمته تتتهي بانتهاء النشاط، بينما تظل علاقة الطفل القرين المعلم مع الطفل القرين المتعلم مستمرة حتي بعد انتهاء النشاط، كما أن استراتيجية تعلم الاقران من استراتيجيات التعلم النشط التي تجعل عملية التعلم متمركزة حول المتعلم وتستجيب لاحتياجات المتعلمين المختلفة والتي يتجاهلها التعليم النمطي، مما يزيد من فعالية وايجابية عملية التعلم، كذلك توافر شروط تطبيق استراتيجية تعلم الاقران مما ساهم في نجاح البرنامج و أوجد قوة تأثيره وقد اتققت تلك النتائج مع عدد من الدراسات التي أكدت علي فعالية استراتيجية تعلم الأقران في تعليم الأطفال في المراحل التعليمية المختلفة ومرحلة الطفولة وخاصة مرحلة رياض الأطفال بشكل خاص مثل دراسة

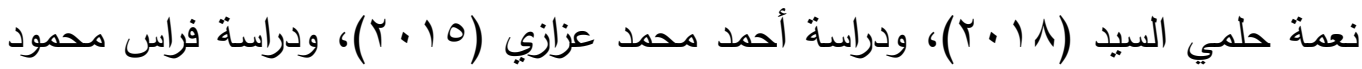

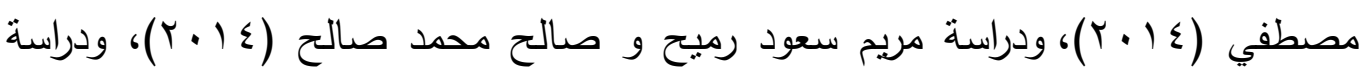

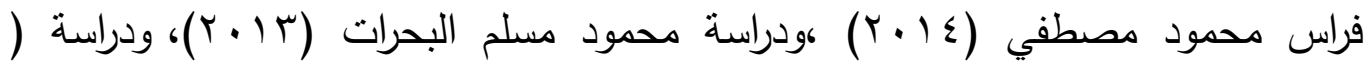

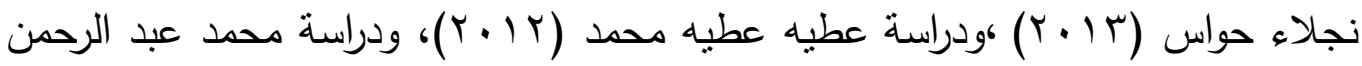
أبو حامد(1) 1 (Y)، ودراسة أحمد محمد نوري و عمار يلدا كرومي(1) (1)، ودراسة وفاء

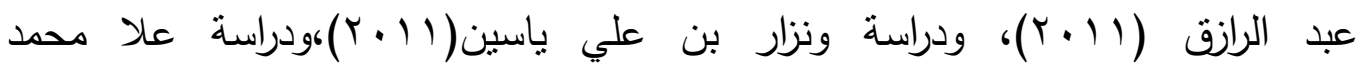

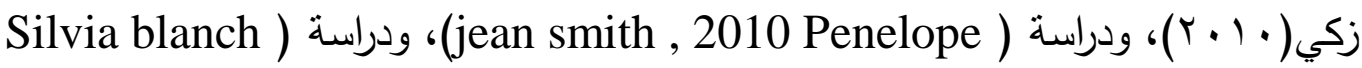
(others , 2012 \&

الفرض الثاني : بنص الفرض الثاني على أنه : يوجــ فـرق دال إحصــائياً بـين متوسـطي درجـات المجمـوعتين الضــابطة والتجريبيـة في التطبيق البعدي علـي مقبـاس الـوعي المـائي لصـالح المجموعـة التجريبية . 
وللتحقق من صحة هذا الفرض تم إيجاد المتوسط الحسابى، والإنحراف المعيارى للمجموعتين الضابطة والتجريبية في القياس البعدي وإيجاد قيمة (ت) كما هو موضح بالجدول

\section{جدول (0)}

دلالة الفروق بين متوسطي التطبيقين البعديين للمجموعتين الضابطة وإلتجريبية

$$
\text { في الوعي المائي }
$$

\begin{tabular}{|c|c|c|c|c|c|c|}
\hline \multirow[b]{2}{*}{ الدلالة } & \multirow[b]{2}{*}{ ق قيمة ت } & \multicolumn{2}{|c|}{ المجموعة التجريبية } & \multicolumn{2}{|c|}{ المجموعة الضابطة } & \multirow[b]{2}{*}{ المقياس } \\
\hline & & الانحراف & المتوسط & الانحراف & المتوسط & \\
\hline 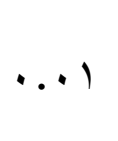 & $\begin{array}{c}*\ulcorner\varepsilon . \sqcap \wedge \\
*\end{array}$ &..$\Delta Y$ & $q . \leqslant r$ & $1 . . V$ & $r . \varepsilon r$ & الوعي المائي \\
\hline
\end{tabular}

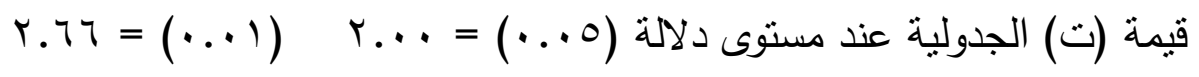

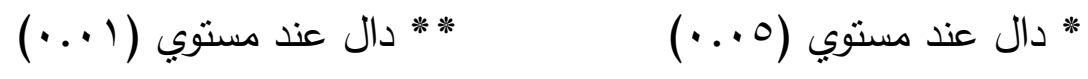

وبالنظر إلى الجدول (0) يتضح وجود فرق دال إحصائياً عند مستوى دلالة (1 (. . ) بين متوسطى التطبيقين البعديين للمجموعة الضابطة والتجرييية فى مقياس الوعي المائي وفى اتجاه

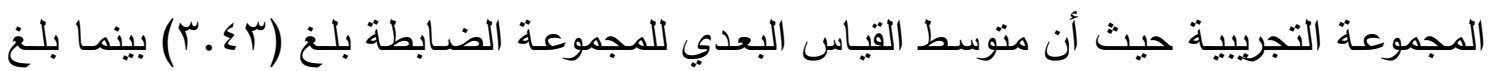

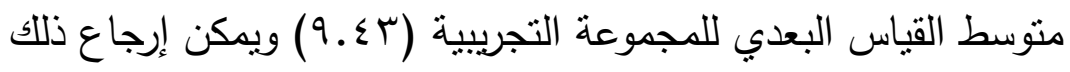
• عدم فعالية الطريقة التقليدية وهى الثرح والتلقين فى تتمية الوعي المائي ويمكن إرجاع ذلك

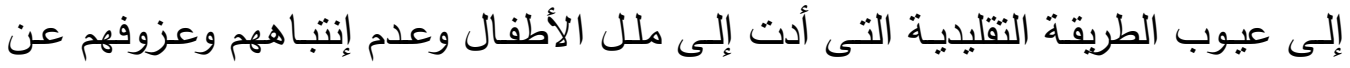
متابعة المعلمة وكذلك عدم اشتراك الأطفال فى القيام بأى أنشطة مما جعهم سلبيين وأدى الفى

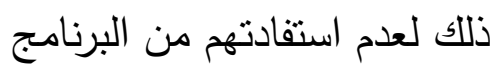

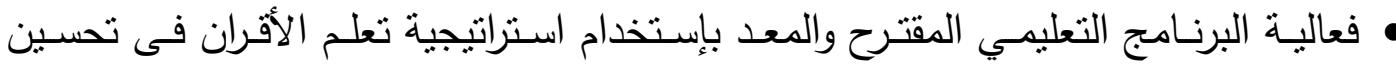

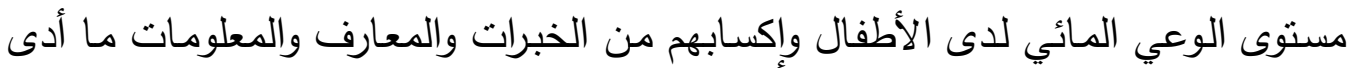
إلى تتمية الوعي المائي.

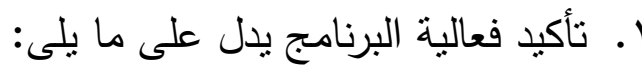
دقة الأهداف المحددة للبرنامج وأنها مصاغة بطرية لهائة إجرائية سليمة وواضحة مما ساعد 
• المحتوى التعليمى للبرنامج تضمن عدد من الموضوعات تمس احتياجات الأطفال وتتتاسب

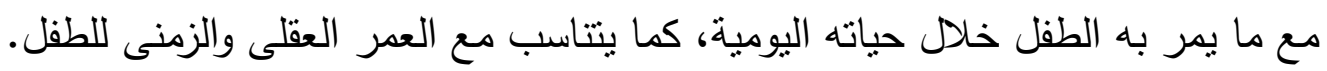
دقة أهداف البرنامج وقدرة المحتوى على تحقيق هذه الأهداف وكذللك قدرة البرنامج على هـى تحقيق الجذب والتشويق يدل على أن البرنامج حقق شروط تتفيذ استراتيجية تعلم الأقران. ا الطرق والأساليب المستخدمة في البرنامج والأنشطة المتضمنة للبرنامج ساعدت فى زيادة فعالية البرنامج، وإسهامها فى تتمية الوعي المائي لدي الأطفال من خلال تفاعل الأطفال

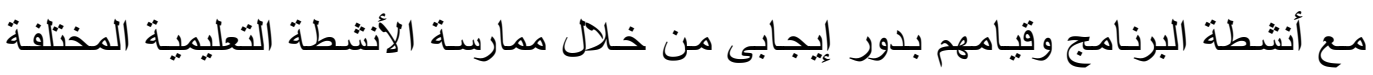
وتفاعلهم مع القرين المعلم وبـذلك تتحقـق صـحة الفرض الثاني بوجـد فـرق دال إحصــائياً بـين متوسـي درجـات

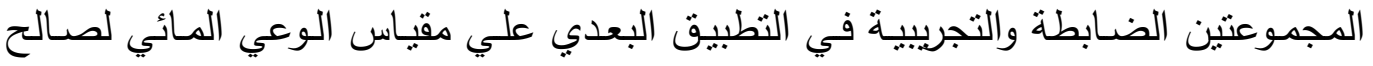

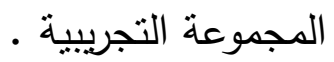
وبمراجعة نتائج الفرضين الأول والثاني يكون قد تمت الإجابة عن التناؤل الثاني من أسئلة البحث والذى ينص على " ما فعالية البرنامج المقترح باستخدام استراتيجية تعلم الأقران في تتمية

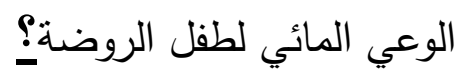

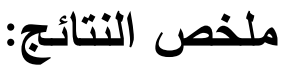

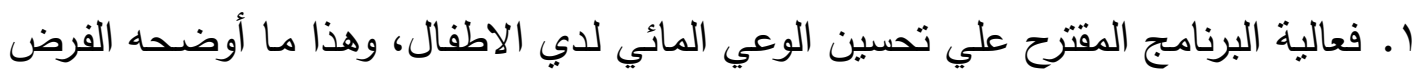

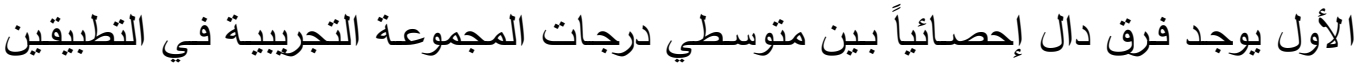

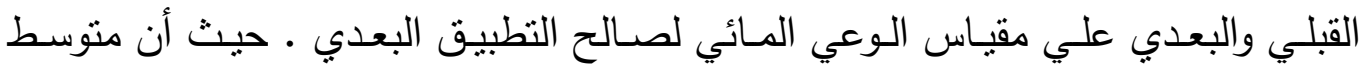

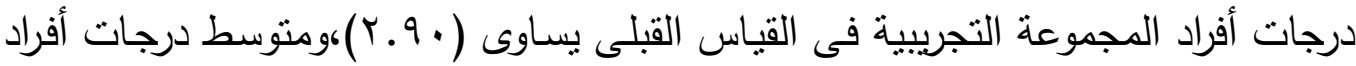
المجموعة التجريبية فى القياس البعدى يساوى (Tـــ9)

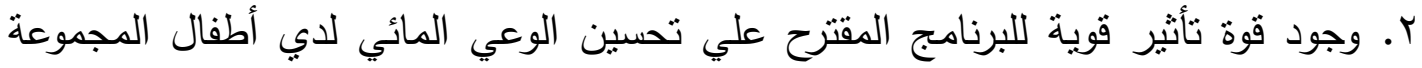

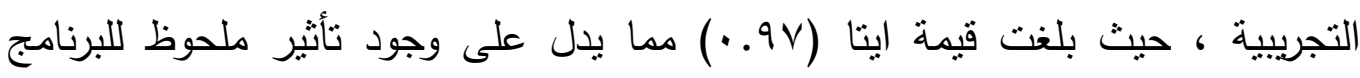

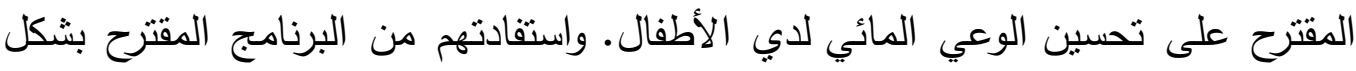
كبير جدا وذلك من خلال تزويدهم بالمعلومات والمفاهيم والسلوكيات المائية الصحيحة من

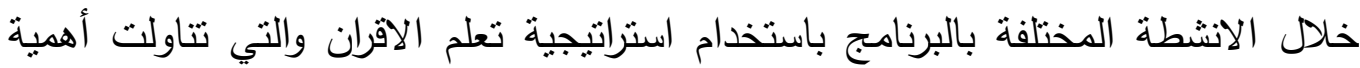
المباه وكيفية المحافظة عليها وطرق ترشيد المياه وتلوث المياه وأسبابه، وكيفية المحافظة

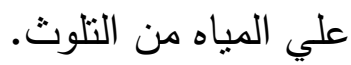


r. فعالية البرنامج المقترح علي تحسين الوعي المائي لدي الأطفال، وهذا ما أوضحته نتائج الفرض الثاني بوجد فرق دال إحصائياً متوسطي درجات المجموعنين الضابطة والتجريبية

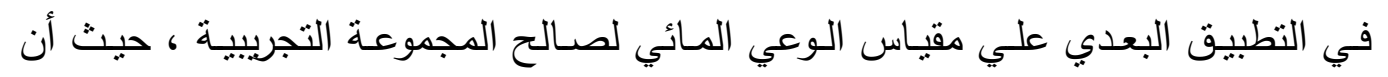

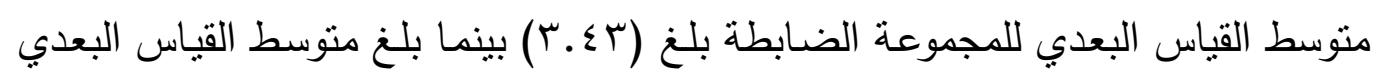

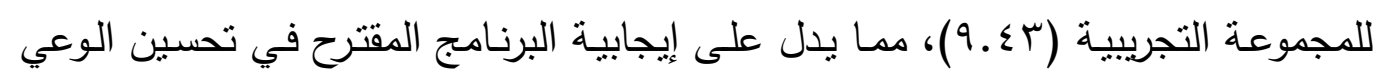

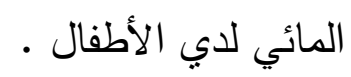
ع. فعالية البرنامج في تحسين الوعي المائي لاي الاطفال باستخدام استراتيجية تعلم الأقران مما يؤكد علي فعاليتها وايجابيتها وترجع الباحثة ذلك لكونها استراتيجية من استراتيجيات التعلم النشط، فهي تتمركز حول المتعلم وتستجيب لاحتياجات الطفل وملاءمة له وتتخطي نمط التعلم التقليدي النمطي، وتزيد من إيجابية المعلم والمتعلم في عملية التعلم، كما يرجع نجاحها أيضاً للعلاقة بين الأقران(القرين المعلم والقرين المتعلم) والتي تتسم بالبساطة والمرونة والتلقائية، كذلك قبول القرين المتعلم للقرين المعلم والتفاعل والتتاغم بينهم يعد سباً قويا في نجاح البرنامج علي عكس علاقته مع المعلمة التي يشوبها في كثير من الأحيان التحفظ والتوتر من قبل الطفل في النمط الثقليدي، حيث كان دور المعلمة في هذه الاستراتيجية ميسرا ومشجعا ومحفزا، فساعد التعزيز والتوجيه الذي تقدمه المعلمة قبل تتفيذ البرنامج و أثنائه علي توفير تعلما نشطا إيجابيا وقد اتفقت تلك النتائج مع عدد من الدراسات التي أكدت علي فعالية استراتيجية تعلم الأقران في تعليم الأطفال في المراحل التعليمبة المختلفة ومرحلة الطفولة وخاصة مرحلة رياض الألفال الطفال

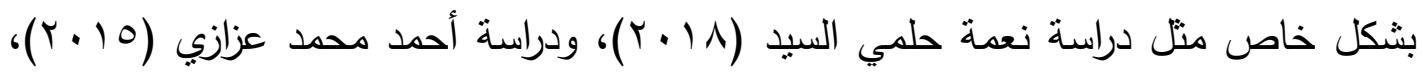

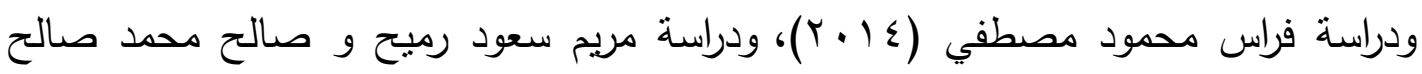

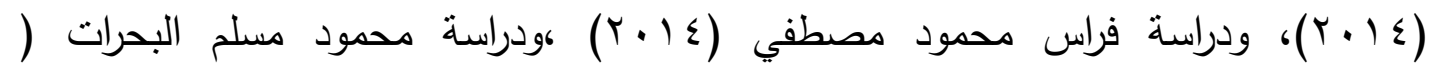

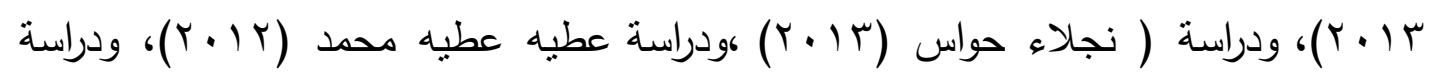

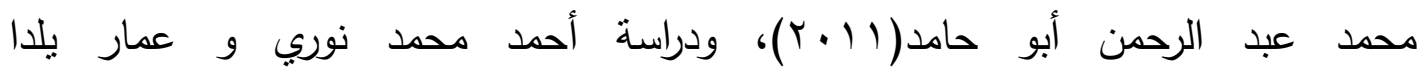

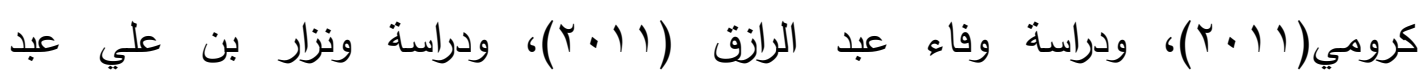

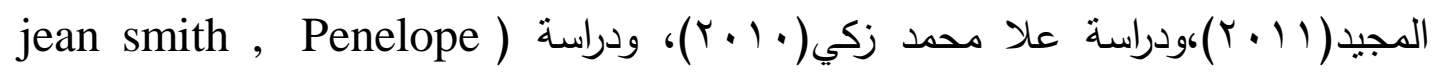
2010)، ودراسة ( others , 2012 \& Silvia blanch 1. تأكيد فعالية البرنامج يدل على ما يلي: 
تحديد ووضوح الأهداف التعليمية للبرنامج المقترح وصياغتها في صورة اجرائية محددة

ساعد على تحقيقها.

شمولية المحتوي التعليمي المقدم وتتاسبه مع العمر العقلي والزمني للأطفال وملائمته لخصائص نمو الطفل المختلفة في تلك المرحلة العمرية.

التتوع والتعدد في الوسائل التعليمية والأنشطة التي استخدمت مع الطفل القرين وقام باستخدامها مع أقرانهما ساعد في اثراء البيئة التعليمية بالمثبرات الحسية حيث روعي في أنشطة البرنامج استخدام الأنثطة المحبية لنفوس الأطفال والملائمة لقدراتهم وإمكاناتهم، حيث ساهمت طبيعة الأنشطة وتعدد الحواس المستخدمة فيها في ترك أثز واضح وبقائها

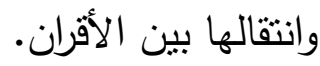

هور المعلمة والذي كان ميسراً ومحفزاً لعملية التعلم على حد سواء مع القرين المعلم والقرين المتعلم وأساليب تعزيزها لهم ساهم ذلك في زيادة فعالية عملية التعلم والتعاون بين القرين المعلم والقرين المتعلم، كما أعطي لها الفرصة في القيام بعملية المتابعة وتقييم عمل القرين

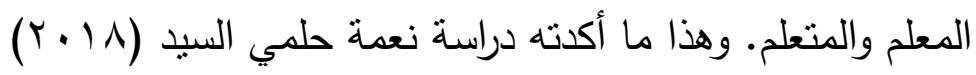
طبيعة استراتيجية تعلم الأقران التي جعلت من المتعلم سواء القرين المعلم أو القرين المتعلم

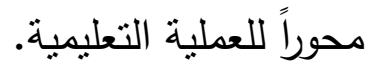

ا. التأكيد على نشر الوعي المائي وتقديم المعلومات والمعارف لأولياء الأمور والأطفال والعاملين في المؤسسات التعليمية المختلفة. r. ربط المؤسسات التعليمية بالمؤسسات التي تهتم بالمياه وتقدم الخدمات المائية من خلال الزيارات الميدانية لها منل (زيارة مرشحات المياه - شركات المياه والصرف الصحي ...الخ). r. اقامة العديد من المسابقات الفنية والمعارض التي تساهم في رفع مستوي الوعي المائي لاي الأطفال والمعلمات وأولياء الأمور • 


\section{في ضوء نتائج البحث تقترح الباحثة اجراء البحوث التالية:}

ا. فعالية برنامج مقترح باستخدام الالعاب الاككترونية في تتمية الوعي المائي لاي أطفاء أبكال

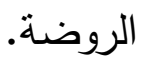

r. برنامج مقترح باستخدام القصص الالكترونية في تتمية الوعي المائي لاي أطفال الروضة. r. برنامج مقترح باستخدام استراتيجية تعلم الاقران في تتمية الدفاهيم التاريخية لدي أطفال

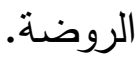

ع. برنامج مقترح في التربية المائية باستخدام استراتيجية تعلم الاقران في تتمية الوعي المائي لدي

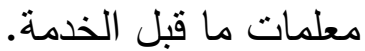

ه. برنامج مقترح باستخدام التعلم عن بعد لتتمية الوعي المائي لدي معلمة رياض الأطفال. 7. برنامج مقترح باستخدام استراتيجية تعلم الاقران في تتمية الوعي المائي لدي الأطفال ذوي الاحتياجات الخاصة بالروضة. 


\section{المراجح?}

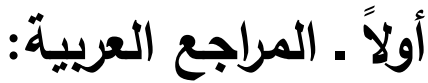

ا. أحمد محمد الحيالي وعمار يلدا هندي (1) (1). أثز استخدام استراتيجية تعليم الأقران في تتمية بعض مهارات القراءة الجهرية والاحتفاظ بها لدي تلاميذ التربية الخاصة في مادة القراءة. مجلة أبحاث كلية التربية الأساسية. جامعة الموصل. المجلد الحادي عشر . العدد الثاني. - إن

r. أحمد محمد عاطف محمد عزازي (10 ب ( ). "فعالية التعلم بمساعدة الأقران في تحسين الأداء الأكاديمي والسلوكي لدي التلاميذ ذوب صعوبات التعلم في غرف المصادر". رسالة دكتوراه. جامعة القاهرة. معهز الدراسات التربوية.

r. أحمد محمد علي رشوان، عبدالوهاب هاشم سيد وهند مكرم عبد الحارس (10 • ب). "فاعلية إستراتيجية تعليم الأقران في تتمية بعض مهارات الكتابة لدى التلاميذ ذوبي صعوبات الكتابة بالمرحلة الابتدائية". المجلة العلمية لكلية التربية. كلية التربية. جامعة أسيوط. العدد (1).

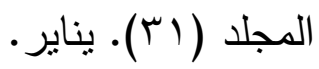
ع. ازدهار أديب الصالحي (9. . ץ). "أثر استراتيجية تعليم الأقران في تصحيح الفهم الخاطئ للمفاهيم الجغرافية لدى طالبات الصف الأول المتوسط". رسالة ماجستير. كلبة التربية، ابن رشد. أغسطس. 0. أزهار محمود حليم، رنا منذر بدري وسكينة جلال محمد (9 ( ب). تقييم مستوى الوعي المائي لاى تلاميذ المراحل الابتدائية قبل وبعد تطبيق برنامج نوعوي، دراسة حالة مدينة بغداد. مجلة بلة القتح. مركز بحوث البيئة. الجامعة التكنولوجية. العراق. بغداد. العدد (•^). كانون الأول. T. أسامة محمد سيد وعباس حلمي الجمل (r Y (Y). أساليب التعليم والتعلم النشط. القاهرة. دار العلم والايمان للنشر والتوزيع.

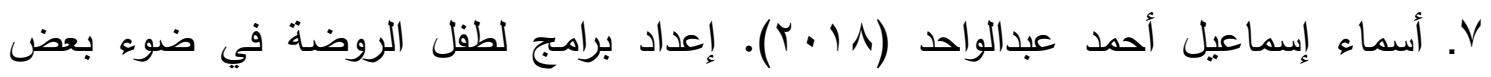
النظريات التزبوية الحديثة. مجلة الطقولة. العدد (rq). مايو. 
^. أسماء عمر سعيد محمد بدوي (Y V Y (Y). فعالية بعض الأنشطة الإعلامية في تتمية الوعي المائي لدى تلاميذ المرحلة الإعدادية. مجلة بحوث التربية النوعية. جامعة المنصورة. كلية

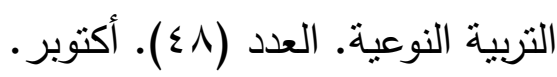

9. آمال محمد بدوي وأسماء فتحي توفيق (9 . +ץ). "التعلم بالاكتشاف والمفاهيم العلمية في رياض الأطفال. ط اـ القاهرة. عالم الكتب.

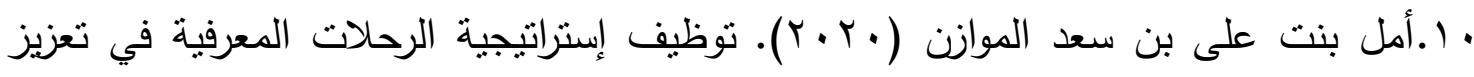
مهارات مجتمعات التعلم المهنية والتوجهات الإيجابية نحو نوظيف التقويم بالأقران لدى الطالبات الجامعيات. المجلة التريوية. جامعة سوهاج. كلية التربية. الجزء (r/) مايو . ا ا ـ أمنة مصطفي علي عمران (Y. V V). "الوعي البيئي ودوره في ترشيد استهلالك المياه". مجلة

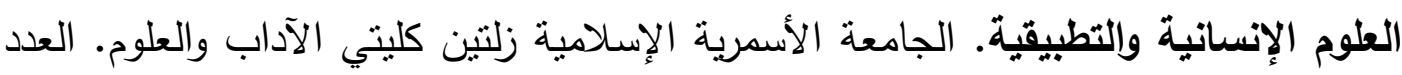

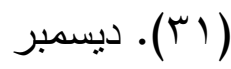

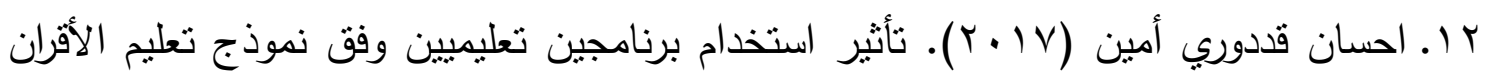
والمجاميع الصغيرة المتجانسة في تعليم فن الأداء والانجاز للوثب الطويل وللاعمار 1 الـr ا سنة ـ مجلة القادية لعلوم التربية الرياضية ـ كلية التربية الرياضية. جامعة القادسية.

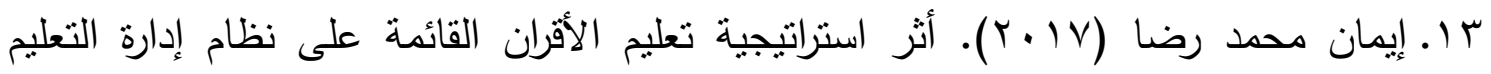
الالكتروني علي تحصيل طالبات قسم الدراسات الإسلامية في جامعة حفر الباطن واتجاهاتهن

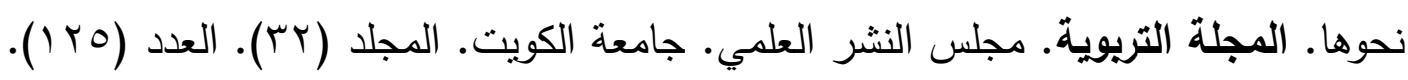
ديسمبر •

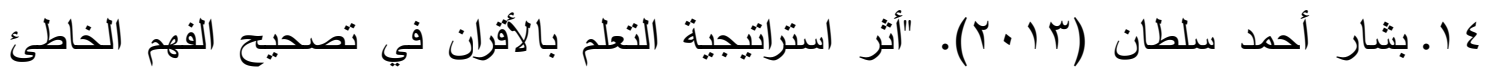
للمفاهيم الرياضية لاي طالبات الصف الثاني المتوسط". رسالة ماجستير. كلية التربية. جامعة تكريت. العراق. 
1 اـ تهاني خليل محمد حسونة (ـ ( ب). "إثراء وحدة في الجغرافيا بأهداف التربية المائية وأثرها في تتمية الوعي المائي لدي طالبات الصف التاسع الأساسي". رسالة ماجستير. كلية التربية.

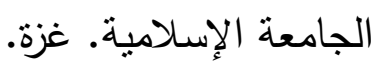

1 1 . ثناء سعيد حسن أبوزيد وهند على حسين شماخي (9 ( ب). فعالية برنامج تدريبي قائم علي بعض استراتيجيات التعلم النشط لنطوير بعض كفايات البحث العلمي لدى طالبات كلية التربية بجامعة جازان. المجلة العربية لعلوم الإعاقة والموهبة. المؤسسة العربية للتربية والعلوم والآداب. كلية التربية. جامعة جازان. المجلد الثالث - العدد (9) أكتوبر .

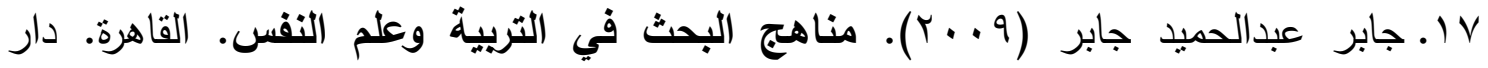
النهضة العربية.

1 ا. جمال حسن السيد ابراهيم (Y V • Y). وحدة جغرافية مقترحة في الأمن المائي العربي لتتمية المفاهيم المائية والوعي بالأمن المائي والحل الابداعي للمشكلات لدي طلاب التعليم الفني.

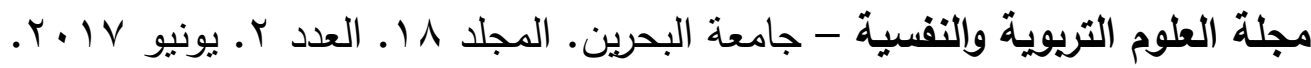
9 1. جودت أحمد سعادة (ץ. (ץ). صياغة الأهداف التريوية والتعليمية في جميع المواد الدراسية. عمان. دار الثروق للنشر والتوزيع.

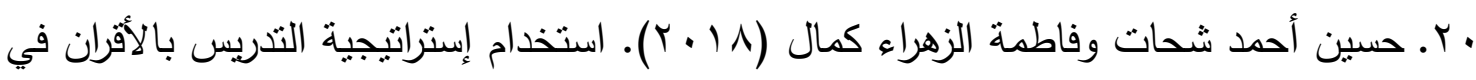
تتمية بعض مهارات التتكيل والتوليف بالخامات والعجائن وبقاء أثز التعلم لدى طلاب التربية الفنية. مجلة امسيا. جمعية إمسيا التربية عن طريق الفن. العدد (ب ا.ـ (). أبريل.

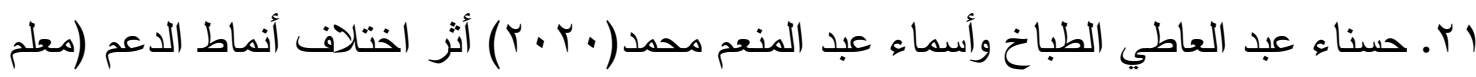
- أقران) ببيئة التعلم السحابية علي تتمية مهارات تصميم بعض تطبيقات الويب لدي طلاب كلية التربية النوعية. 2.0 المجلة التربوية. تصدر عن كلية التربية. جامعة سوهاج الجزء $\cdot(\mathrm{V} 0)$

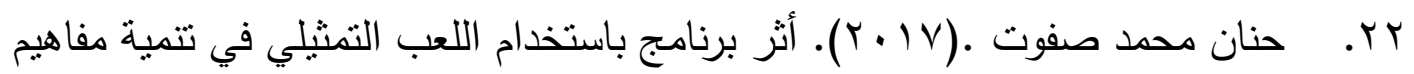
وسلوكيات ترشيد الاستهلاك لدى أطفال الروضة ذوي صعوبات التعلم. مجلة دراسات في الطفولة

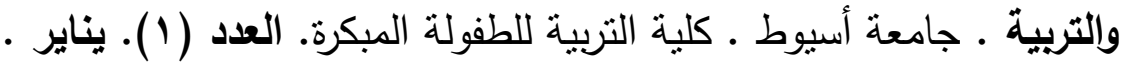




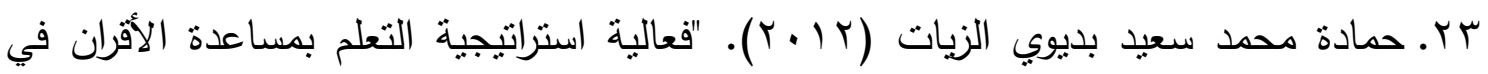

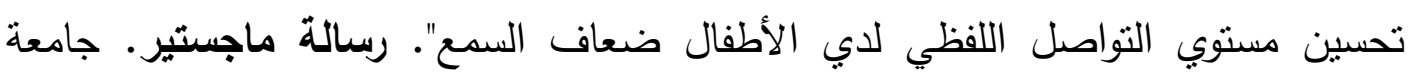
الزقازيق. كلية التربية.

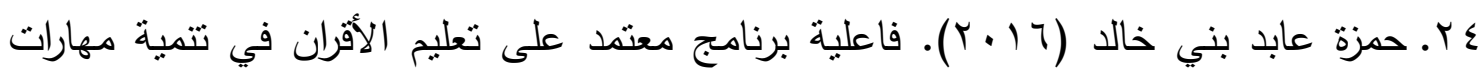
الرياضيات لدي عينة من ذوي صعوبات التعلم. مجلة المعهد الدولي للاراسة والبحث. جدة. المعهد الدولي للاراسة والبحث. العدد (Y). المجلد (Y). فبراير •

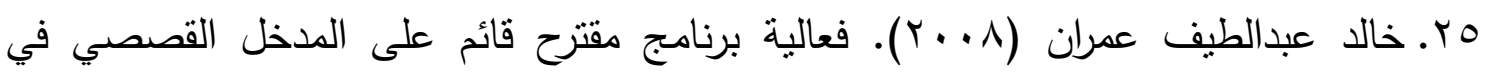
تدريس الدراسات الاجتماعية لتحقيق بعض أهداف التربية المائية لدي تلاميذ الصف السادس برس الابتدائي. المجلة التريوية. تصدر عن كلية التربية. جامعة سوهاج. العدد (ع ب). يناير . Tr. خضير عباس جري ورعد جميل حجي (10 +Y). "أثر استراتيجية تعلم بالأقران في تتمية الفهم الجغرافي لدي تلاميذ الصف الخامس الابتدائي". مجلة العلوم التربوية والنفسية. الجمعية العراقية للعلوم التربوية والنفسية. العدد ع 11.

V V. دعاء زكريا (9 . . r). تنمية الموارد المائية في الوطن العربي. القاهرة. الدار الثقافية للنشر .

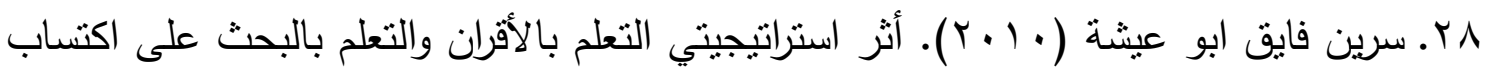
مهارات ايجاد النهاية والاحتفاظ بها لدي طالبات الثانوية العامة بغزة. رسالة ماجستير. كلية التربية. الجامعة الإسلامية. غزة. فلسطين.

9. سعيد محمد محمد السعيد وصالح بن عبداله العجاجي (10 • ب). "دور مناهج العلوم المطورة بالمرحلة المتوسطة في تتمية الوعي المائي لدي الطلاب بمنطقة القصيم: دراسة تقويمية. مجلة دراسات في المناهج وطرق التدريس. الجمعية المصرية للمناهج وطرق التدريس

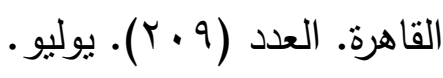

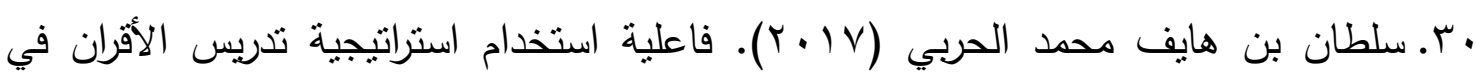
علاج صعوبات القراءة الجهرية لاى تلاميذ الصف السادس الابتدائي في محافظة حفر الباطن بالسعودية. مجلة العلوم التريوية والنفسية. المركز القومي للبحوث بغزة. المجلد (1).

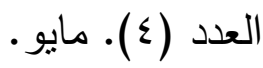


اس. سماح محمد عبداله حداد (· • (r). "برنامج لتتمية بعض المفاهيم البيئية والسلوكيات الإيجابية المرتبطة بها لدي أطفال الروضة بالجمهورية اليمنية". رسالة ماجستير. جامعة عين شمس. معهد الدراسات العليا للطفولة.

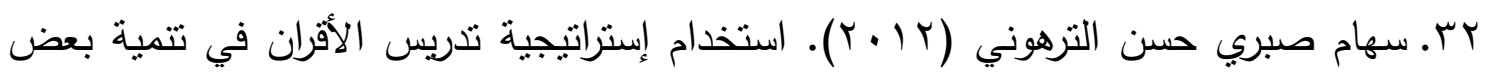
عمليات التفكير من خلال مادة الجغرافيا لدى تلاميذ المرحلة الإعدادية. مجلة كلية التريية. جامعة طنطا. العدد الرابع (ع ^). أكتوبر •

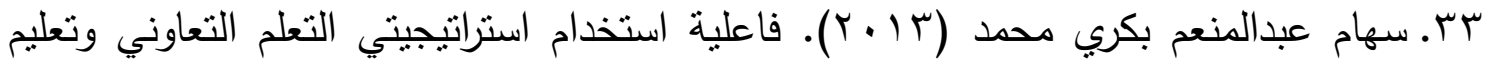
الأقران في خفض صعوبات التعلم لدى تلميذات المرحلة الابتدائية. رسالة دكتوراه. معهد الدراسات التربوية. قسم الإرشاد النفسي والتربوي، جامعة القاهرة. ع ا. صباح بنت محمد بن عبداله العرفج ( • • ( ). فاعلية وحدة مقترحة في الاقتصاد المنزلي قائمة علي البنائية لتنمية بعض المفاهيم والمهارات الحياتية المتعلقة بالتربية المائية لدي تلميذات الصف السادس الابتدائي. رسالة دكتوراه. كلية المجتمع بالإحساء. جامعة الملك فيصل.

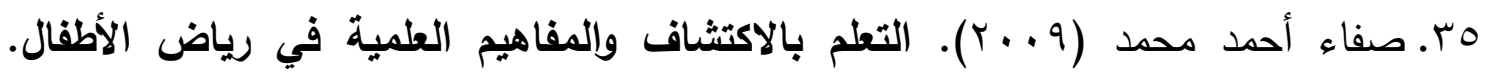

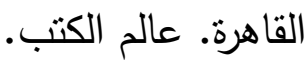

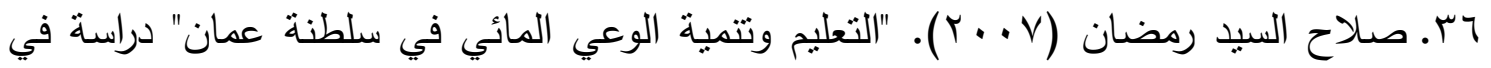
مضمون بعض المقررات الدراسية. مجلة دراسات في المناهج وطرق التدريس. تصدر عن الجمعية المصرية للمناهج وطرق التدريس. فبراير •

Vr. طارق علي فرج الخضري(ء ( ب). فعالية أسلوبي التعلم الأقران - الذاتي علي تتمية بعض المهارات الحركية ومستوي التحصيل المعرفي لتلاميذ المرحلة المتوسطة بدولة الكويت.مجلة

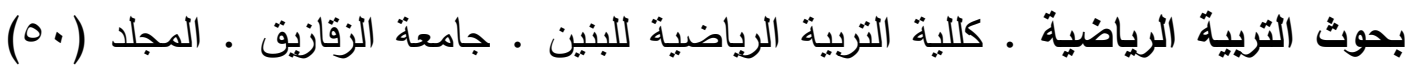

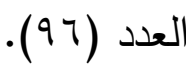




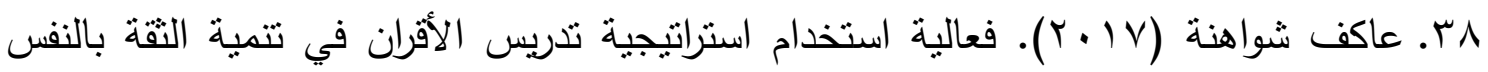
وعلاقتها بالتحصيل". مجلة العلوم التريوية. جامعة القاهرة. كلية الدراسات العليا للتربية.

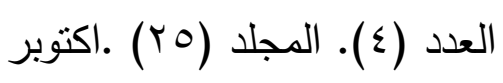

q ب. عباس محمد شراقي (ع ( • ب). المياه في أفريقيا والعالم العربي. مجلة وصلة. الهيئة المصرية

$$
\text { العامة للكتاب. العدد ( • () • يوليو. }
$$

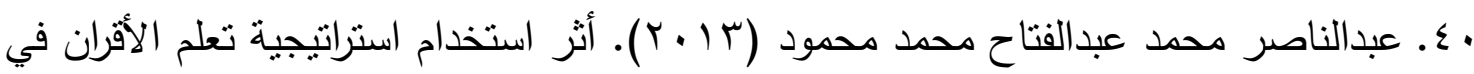
تتمية التفكير الايجابي وتقدير الذات لذوي التحصيل المنخفض والمرتفع من تلاميذ مرحلة التعليم الأساسي. رسالة دكتوراه. جامعة القاهرة. معهد الدراسات التزبوية. اءع. عرين عبداله الرواثندة (ع ( • ب). "بناء مصفوفة المدي والتتابع للبنية المعرفية للتربية المائية في كتب الجغرافيا للمرحلة الأساسية في الأردن". رسالة دكتوراة. كلية التربية. جامعة

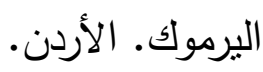

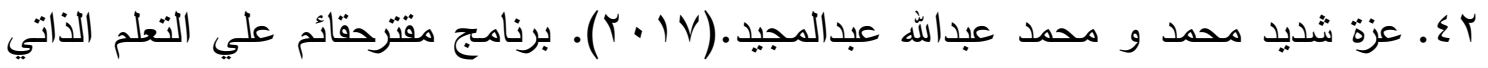
لتتمية الوعي بقضايا المياه في مصر للطلاب معلمي العلوم والدراسات الاجتماعية.المجلة

$$
\text { المصرية للتربية العلمية. المجلد (•r) العدد( •؟). }
$$

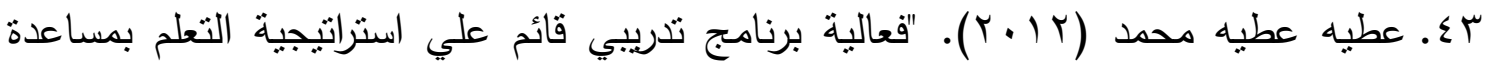
الأقران في تصحيح عيوب النطق لدي الأطفال ضعاف السمع. مجلة دراسات تربوية ونفسية. تصدر عن مجلة كلية التربية بالزقازيق. العدد الرابع والسبعون. يناير.

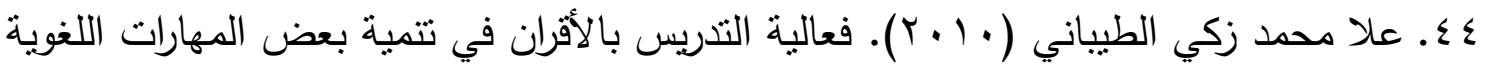
للأطفال ذوي متلازمة داون المدمجين مجلة الطفولة والتربية كلية رياض الأطفال. جامعة

$$
\text { الإسكندرية. السنة (r) العدد (0). الجزء (ץ). }
$$

0ـ. عمار فالح حسن .(r • (ץ) ـ فاعلية استراتيجية تدريس الأقران في تحصيل مبادئ الأحياء والحكم الخلقي لدي طلاب الصف الأول المتوسط .رسالة ماجستير.كلية التربية . جامعة 
جـ. عنايات محمد محمود خليل (11 • ب). استخدام استراتيجيتي الألعاب التعليمية وتعليم الأقران والدمج بينهما في تعليم المفاهيم والاستماع والتذوق بينهما في تعليم مفاهيم الاستماع والتذوق الموسيقي لدي الأطفال المتخلفين عقليا " القابلين للتعلم". مجلة دراسات في المناهج وطرق

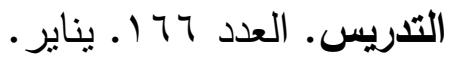

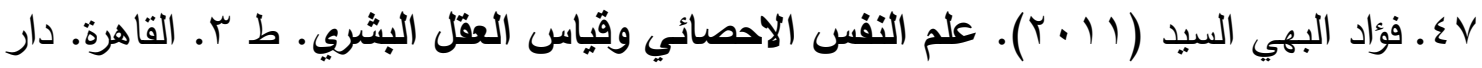

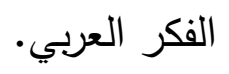

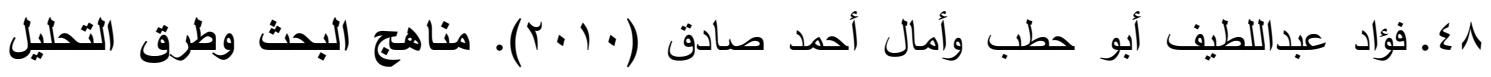
الاحصائي في العلوم النفسية والتريوية والاجتماعية. ط ا ـ القاهرة. الانجلو المصرية. 9ء فاطمة أحمد إبراهيم غريب (1 (1 ب). فاعلية برنامج مقترح لتتمية وعي طفل الروضة بأهمية المحافظة على الموارد المائية في ضوء متطلبات العصر من خلال بعض الأنشطة الموسيقية والأغاني المبتكرة. المؤتمر العلمي السنوي العربي السادس والدولي الثالث لكلية

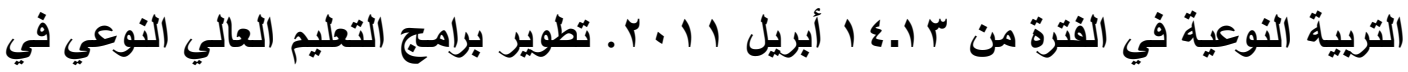
مصر والوطن العربي في ضوء متطلبات عصر المعرفة. المجلد الثالث. • ه. فاطمة عبدالحميدٌ أبو النوارج، زينُب محمود أحمد، حجاج محمد حجاج وحمود مناح راكان السبيعي (9 ( • r). أثز استخدام إستراتيجية جعلن الأقران في تدريس التربية الفنية على تتمية بعض المفاهيم والمهارات الفنية اليدوية لدي طلاب المرحلة المتوسطة بدولة الكويت. مجلة شباب الباحثين. كلية التربية. جامعة سوهاج.

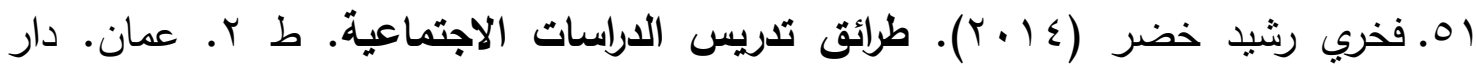
المسيرة.

ro. فراس محمود مصطفي السليني وفؤاد فلاح محمد مقدادي (1/ • r). "أثز استخدام استراتيجية التعلم بالأقران في تحصيل طلاب الصف الخامس الأساسي في قواعد اللغة العربية في الأردن". مجلة جامعة القدس المفتوحة للأبحاث والدراسات التريوية والنفسية. جامعة القدس. المجلد الثالث - ع (Yr) - تشرين الأول. 


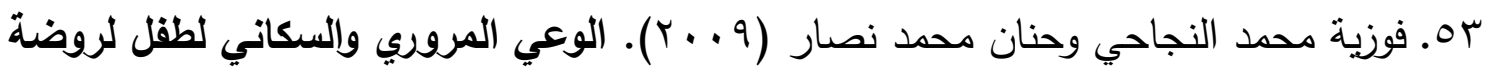
(دراسات وأنشطة). القاهرة. دار الكتاب الحديث.

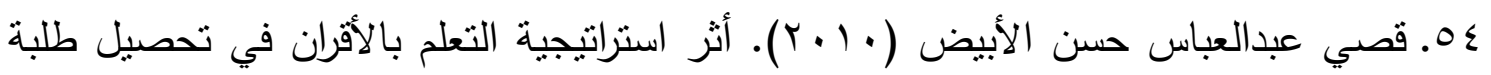
الصف الخامس الاعدادي في مادة قواعد اللغة العربية. كلية التربية الأساسية. الجامعة

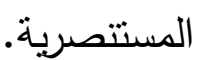

00. قيس حمادي العبيدي (11 + (1). التوعية والتربية المائية. مجلة أبحاث كلية التربية الأساسية. جامعة الموصل. بغداد. المجلد 11اـ العدد I.

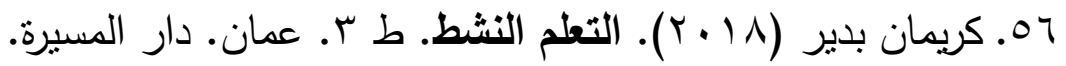

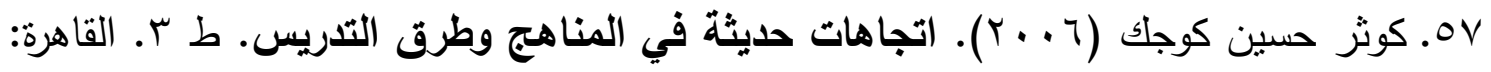

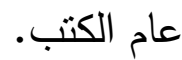

01.كوثر محمد الثناذلي العديسي (ع (ب). أثز استراتيجية لعب الأدوار في تتمية الوعي الاقتصادي الاستهلاكي لدي أطفال الروضة. رسالة ماجستير . كلية التربية. جامعة جنوب

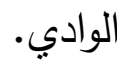

09. ماجدة فتحي سليم (1 ( • ץ). "أثر استخدام استراتيجية عظم السمكة على تتمية الوعي المائي في وحدة الماء لاى أطفال الروضة". مجلة الطفولة والتريية. مايو • جامعة الإسكندرية. كلية

$$
\text { رياض الأطفال. المجلد (· (1). العدد (rr). ينابر }
$$

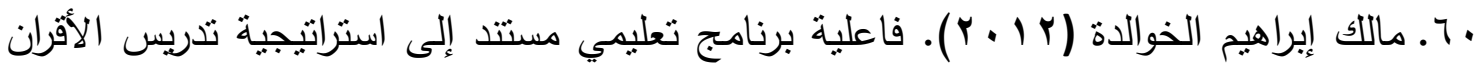
في تتمية مهارات التفكير الإبداعي وتحسين مستوى الدافعية للتعلم لدى الطلبة الموهوبين. رسالة دكتوراه. جامعة عمان العربية، الأردن.

ا7. محمد السيد علي (11 + r). موسوعة المصطلحات التريوية. عمان. دار المسيرة.

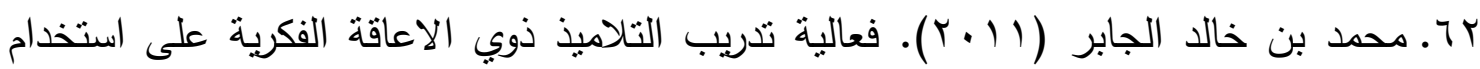
الحاسب الآلي عن طريق الأقران. رسالة ماجستير. كلية التربية. جامعة الملك سعود. 
با7. محمد عبدالتواب أبو النور، آمال جمعة عبدالفتاح، سامية محمد محمود وجمال فرحات (T ( ا ( ). فاعلية استخدام استراتيجية تدريس الأقران في تتمية المهارات الأساسية في اللغة العربية لدي طلاب كلية التربية غير المتخصصين واتجاهاتهم نحو استخدام الاستراتيجية. مجلة كلية التربية. جامعة الفيوم. م.

ـ 7. محمد عبدالرحمن أحمد أبو حامد (11 (Y). فاعلية تعليم الأقران بمساعدة الكمبيوتز في تدريس العلوم لتلاميذ المرحلة الابتدائية واكتسابهم بعض المفاهيم العلمية وبعض مهارات التفاعل الاجتماعي. رسالة ماجستير . كلية التربية. جامعة المنيا.

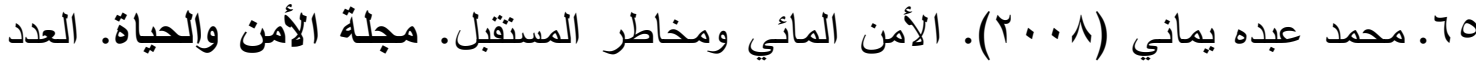
ثلاثة مائة وعشرة. السنة السابعة والعشرون. الرياض. جامعة نايف. أبريل.

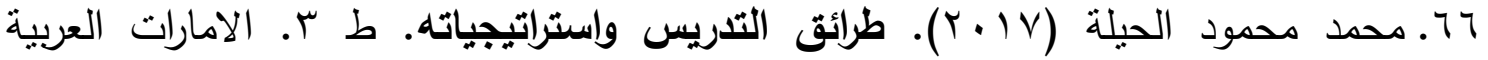
المتحدة. دار الكتاب الجامعي.

V7. محمود ابراهيم عبدالعزبز (111 • (Y). "تطوير منهج المساحة والري في ضوء أبعاد التربية المائية وأثره في تتمية الوعي المائي لدي طلاب الصف الأول الثانوي الزراعي". المجلة المصرية للتربية العلمية. تصدر عن الجمعية المصرية للتربية العلمية. العدد (1). المجلد

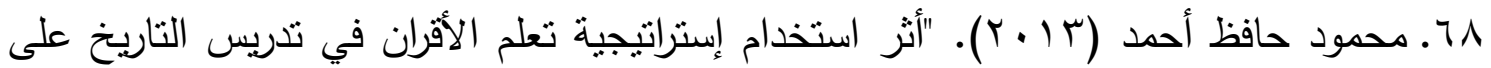
تتمية مفهوم الذات والاتجاه نحو المادة لدى طلاب الصف الأول الثانوي". مجلة الجمعية التربوية للاراسات الاجتماعية. الجمعية التربوبة للدراسات الاجتماعية. العدد (00). ديسمبر . 9. محمود مسلم البحرات. (با • ץ). تقديم التعلم باستخدام التعلم استراتيجيتي الأقران والمناظرة وأثره في التحصيل والتفكير الاستقرائي في مادة التربية الاجتماعية للصف السادس الأساسي. رسالة ماجستير جامعة الثرق الأوسط. كلية العلوم التربوية. • V. محمود موسي فتيحة وأحمد محي الدين الكيلاني (Y V • P). أثز إستراتيجية التعلم بالأقران ونموذج دورة التعلم السباعية في تحصيل طلاب الصف العاشر الأساسي في مبحث التربية 
الإسلامية. مجلة البلقاء للبحوث والدراسات. جامعة عمان الأهلية - عمادة الدراسات العليا

$$
\text { والبحث العلمي. المجلد (•r). العدد (r). }
$$

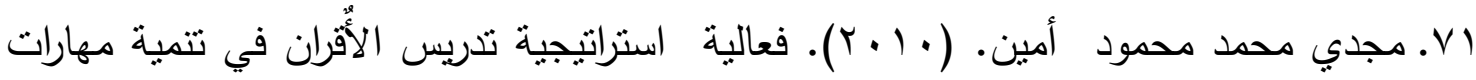
تخطيط وتتفيذ وتقويم دروس مادة التربية الفنية وفي انتقال وبقاء أثز تعلمها لدي الطلاب المعلمين بكلية التربية النوعية - جامعة القاهرة.المؤتمر العلمي السنوي العربي الخامس الدولي الثاني . الاتجهات الحديثة في تطوير الأداء المؤسسي والأكاديمي في مؤسسات التعليم العالي النوعي في مصر والعالم العربي.كلية التربية النوعية ـ جامعة المنصورة المجلد

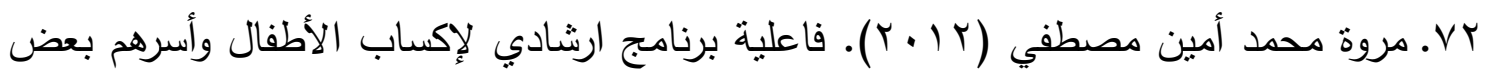
المفاهيم الاقتصادية في مرحلة الطفولة المبكرة. رسالة دكتوراه. جامعة عين شمس. كلية

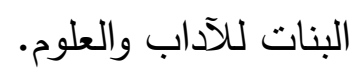

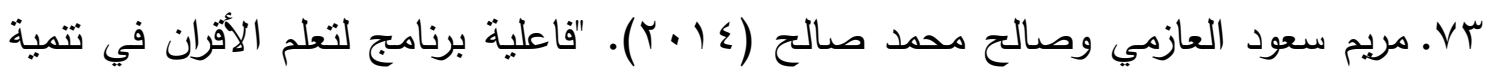
حل المشكلات والدافعية للإنجاز لدى الأطفال". عالم التربية. المؤسسة العربية للاستثارات

$$
\text { العلمية وتتمية الموارد البشرية". س (0 (1). ع (مץ). أكتوبر. }
$$

ع V. مهدي حمود سالم (1 . ب). الأهداف السلوكية (تحديدها - مصادرها - صياغتها -

$$
\text { تطبيقاتها). ط س. الرياض. العبيكان. }
$$

ه V. موفق عرفة معروف (· ( • ( ). مستوي الوعي المائي لدي الطلبة معلمي العلوم بكليات التربية في الجامعات الفلسطينية بغزة. رسالة ماجستير. كلية التربية. الجامعة الاسلامية. غزة. فلسطين.

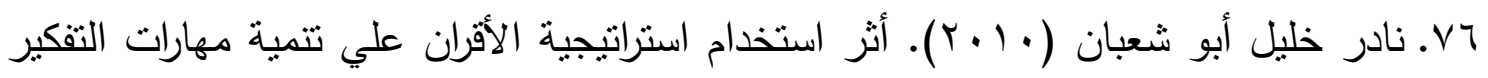
الناقد في الرياضيات لدي طالبات الصف الحادي عشر قسم العلوم الإنسانية (الأدبي) بغزة. رسالة ماجستير. كلية التربية. الجامعة الاسلامية. غزة. فلسطين. 


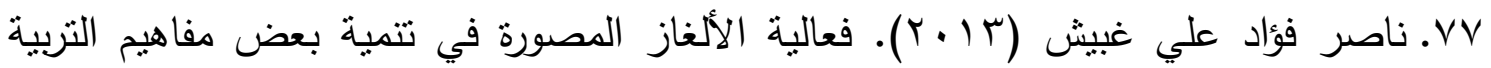
المائية لدي أطفال الروضة. مجلة دراسات عربية في التريية وعلم النفس. تصدر عن رابطة التربوبين العرب. العدد السابع والثلاثون. الجزء الرابع. مايو .

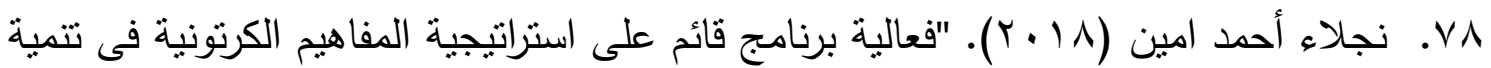
الوعي المائى لدى طفل الروضة". مجلة دراسات في الطقولة والتربية جامعة أسيوط. كلية

$$
\text { رياض الأطفال. العدد (V). أكتوبر • }
$$

9. نجلاء يوسف حواس. (T/ • (Y). برنامج مقترح قائم على استراتيجية تعلم الاقران بعض المهارات اللغوية واثرة على اكتساب بعض المهارات الاجتماعية لدى الاطفال بطيئى التعلم فى رياض الاطفال. مجلة كلية التربية ببورسعيد. العدد الرابع عشر . الجزء الأول. • 1. نجوان عباس محمود همام (• ( •). تعليم الأقرن كاستراتيجية تدريسية لزيادة التحصيل الأكاديمي والتفاعل الاجتماعي لذوي الاعاقة "دراسة تحليلية". مجلة العلوم التريوية عدد خاص. المؤتمر الدولي السابع 0 ا.ب 1 يوليو. المجلد الأول. المجلد الثامن عشر .

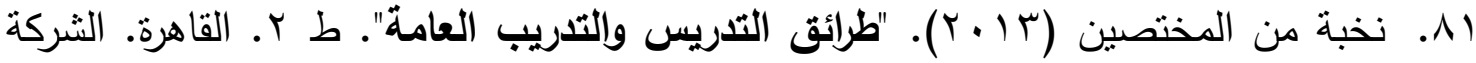
العربية المتحدة للتسويق والتوريدات".

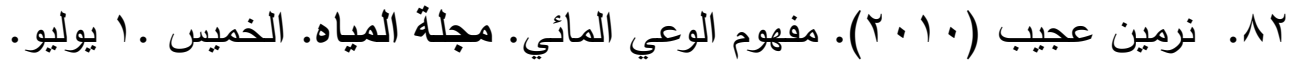
بـ. نزار بن علي عبدالمجيد (11 (ب). استخدام استراتيجية تدريس الأقران في تدريس التربية الفنية وعلاقتها ببعض المخرجات التعليمية لدي تلاميذ المرحلة الابتدائية بمدينة جدة. رسالة ماجستير. كلية التربية. جامعة أم القري. المملكة العربية السعودية.

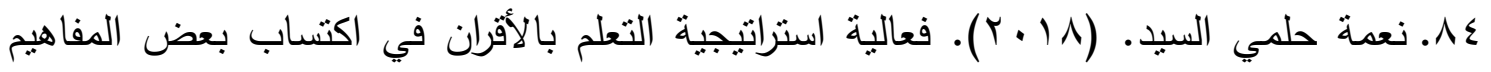
اللغوية لدي الطفل البدوي بمطروح. رسالة ماجستير. كلية التربية للطفولة المبكرة جامعة مطروح. 


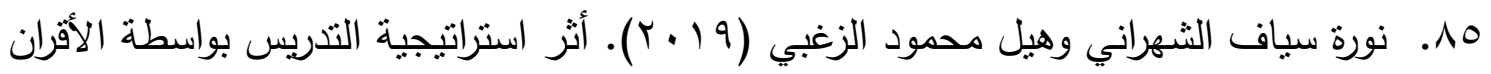

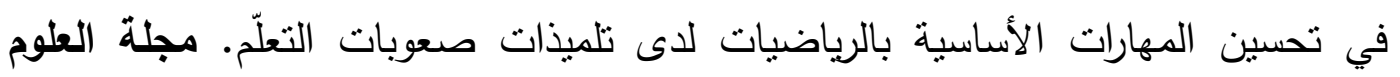
التريوية. جامعة قطر . كلية التربية. العدد (ع ().)

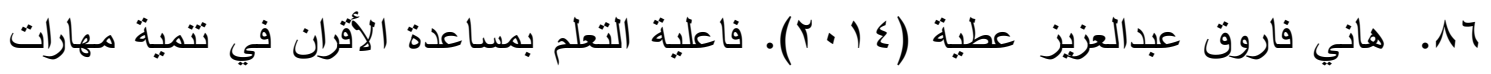
حل المشكلات ودافعية الإنجاز لدى تلاميذ المرحلة الابتدائية. رسالة ماجستير. معرد الدراسات التربوية. قسم علم النفس التربوي، جامعة القاهرة. AV التبادلي وتدريس الدراسات الاجتماعية. القاهرة. العربية للمناهج المنطورة للبرمجيات. 11. هند مكرم عبدالحارس عبدالمالك (؟ ( ب). برنامج فى اللغة العربية قائم على تعليم الاقران لتتمية بعض مهارات الكتابة لدى التلاميذ ذوي صعوبات الكتابة بالمرحلة الابتدائية. رسالة ماجستير . كلية التربية. جامعة أسيوط.

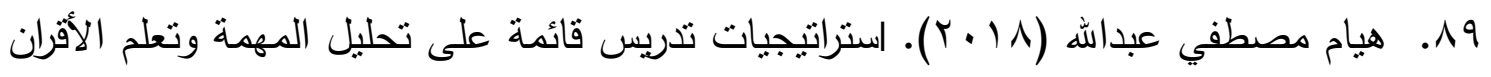
لتتمية التحصيل المعرفي وبعض المهارات العملية في مادة "أصول فن الطهو" لدى الطالبات ذوات صعوبات التعلم بالددارس الثانوية الفنية. دراسات في المناهج وطرق التدريس. جامعة عين شمس - كلية التربية - الجمعية المصرية للمناهج وطرق التدريس. العدد

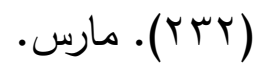
•9.وحيد حامد عبدالوهاب (•(Y. (Y). "فاعلية استخدام استراتيجية تكريس الأقران في تحصيل القواعد النحوية وتتمية بعض مهارات التعبير الثففي والكتابي لدي تلاميذ الصف السادس الابتدائي". المجلة العلمية. تصدر عن كلية التربية بالوادي الجديد. العدد الرابع. ديسمبر • . . . 19. وفاء عبدالرزاق (1) • (1). أثر استخدام تعليم الأقران في تحصيل تلميذات الصف الخامس الابتدائي في مادة العلوم العامة، مجلة العلوم الانسانية، تصدر عن كلية التربية للعلوم

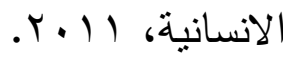




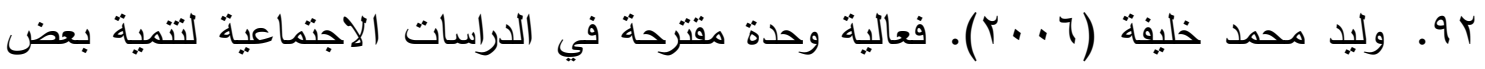
المفاهيم المائية والوعي المائي لدي تلاميذ الصف الأول الاعدادي. رسالة ماجستير. كلية

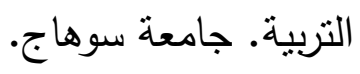

بو. وليد محمد خليفة (9 . . r). التربية المائية ومناهج الدراسات الاجتماعية. كفر الثيخ. العلم والايمان للنشر والتوزيع.

ع 9. وليد محمد خليفة (• ( • ). فاعلية برنامج مقترح في الجغرافيا قائم على البنائية الاجتماعية باستخدام التعلم الخليط في التحصيل المعرفي وتتمية مهارات التربية المائية والمعتقدات البيئة لدي الطلاب المعلمين بكلية التربية. رسالة دكتوراه. كلية التربية. جامعة سوهاج. 9. وليد محمد خليفة (9 ( • ). "أثز برنامج مقترح في الجغرافيا باستخدام الويكي WIKI علي التحصيل المعرفي الحل الإبداعي للمشكلات المائية لدي طلاب جامعة بيشة". مجلة كلية التربية. جامعة أسيوط .كلية التربية. المجلد (0r). العدد (0). مايو.

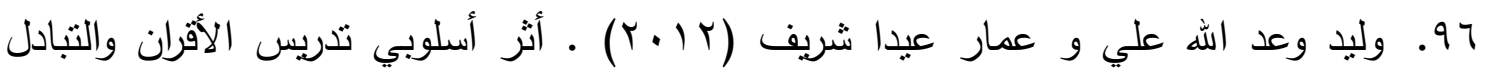
الثلاثي في اكساب واستثمار وقت التعليم الأكاديمي لبعض المهارات الأساسية بالتنس .مجلة جامعة كركوك للدراسات الانسانية.جامعة كركوك .المجلد (V) ـ العدد (ץ). 97.Amanda Justine Horvath (2010). "WATER EDUCATION IN PARAGUAY". The degree of Master of Science Environmental Sciences. University of Colorado Denver in partial fulfillment.

98.Amy N. Colgrove (2012)." APPROACHES TO TEACHING YOUNG CHILDREN SCIENCE CONCEPTS AND VOCABULARY AND SCIENTIFIC PROBLEM-SOLVING SKILLS AND ROLE OFCLASSROOM ENVIRONMENT". For the Degree of. Master of Science. Lincoln. University of Nebraska. June 14, 2012. 
99.Annie Bleeker (2001). Presentation for 2 international drugs and young people conference. Melbourne. Australia 4-6 Apr. http://www.peer.ca/ableeker.pdf.

100. Bron, Jeroen. van Vliet, Eddie (2013). Water Education in the Netherlands: An Integrated Curriculum Using NCSS Standards for Social Studies. Social Education. Vol. 77, No. 3, p.p. 150-156 MayJun 2013.

101. Bülent Aydoğdu, Aysun Çakır (2016). An Investigation of Middle School Students' Attitudes and Awareness of Water Use. INTERNATIONAL JOURNAL OF ENVIRONMENTAL \& SCIENCE EDUCATION. Afyon Kocatepe University. TURKEY. Vol. 11, No. 16, p.p. 9520-9536.

102. K. Brinkley (2011). Peer Teaching. Tennessee Teaching and Learning Center. http://tenntlc.utk.edu

103. Candice .M.Jostad Raymond G. Miltenberger, Pamela Kelso \& Peter Knudson (2008). Peer tutoring to prevent firearm play. acquisition Generalization, and long term maintenance of softy skills. Journal of applied behavior analysis. Vol. 41. Spring 2008.

104. Coban, Gul Unal; Akpinar, Ercan; Kucukcankurtaran, Evren; Yildiz, Eylem \& Ergin, Omer (2011). Elementary School Students' Water Awareness. International Research in Geographical and Environmental Education. Vo;. 20, No. 1, p.p. 65-83 Feb. 2011.

105. Courtney T. Owens \& Alexa J. Lamm (2017). The Politics of Extension Water Programming: Determining if Affiliation Impacts 
Participation. Journal of Agricultural Education, Vol. 58, Issue 1, 2017, p.p. 54-68. https://doi.org/10.5032/jae.2017.01054

106. EMILY EVANS (2012). "Learning Connections, Children's Perceptions, and the Role of lace in Water Education". DISSERTATION for the degree of DOCTOR OF PHILOSOPHY. UNIVERSITY OF CALIFORNIA. Department of environment and natural resources division of pollution (2002).water conservation checklist .schools education Facilities MAIL. august.

107. Geokge, J. Dupaul; Rutha. Ervin; Christinel. Hook \& Karae Mcgoey (1998). Peer tutoring for children with attention defictson classroom behavior and academic.APPLIED BEHAVIOR ANALYSIS 1998, 31, p.p. 579-592. No. 4, (WINTER 1998) perforanance.

108. Georgina Victoria (2014). Water literacy and citizenship: education for sustainable domestic water use in the East Midlands. Ph.D. thesis, University of Nottingham. http://eprints.nottingham.ac.uk/id/eprint/14328

109. Lumyai Seehamat1, Unchalee Sanrattana1 \& Angkana Tungkasamit1 (2016). "The Developing on Awareness of Water Resources Management of Grade 6 Students in Namphong Sub-Basin". International Education Studies. Published by Canadian Center of Science and Education. Vol. 9, No. 5; 2016. ISSN 1913-9020 E-ISSN 1913-9039.

110. M.R.F. Nazreen (2012) .Assessment on awareness of school children on water and water conservation. www.saciwaters.org/.../extended $\% 20$ abstracts\%20M.R.F. 
111. Mustafa DOĞRU \& Fatih ŞEKER (2012). "The Effect of Science Activities on Concept Acquisition of Age 5-6 Children Groups". Educational Sciences: Theory \& Practice-Educational Consultancy and Research Center Special Issue. Autumn. P.p. 3011-3024.

112. Nathern, S.A. Okiwa \& Liz Shelby (2010). The effect of peer tutoring on academic performance of students with disabilities remedial and speared education. ham mill institute. The University of Texas-Austin.

113. Omar K.M. Ouda (2013). Towards assessment of Saudi Arabia public awareness of water shortage problem. Resources and Environment, Vol. 3, No. 1, p.p. 10-13.

114. Oscar Anson, Diego Gutierrez (2004). A sustainable framework for itbased water education. kasetsart university. Thailand.

115. P.W. Soo \& C.S. Cheam (2012). "A Practical Approach to Water Education in Secondary Schools in Penang, Malaysia". Geophysical Research Abstracts. EGU General Assembly. Vol. 14, EGU 201214080, 2012.

116. Penelope Jean Smith (2010). The role of peers in children's learning a thesis presented in partial fulfillment of the requirements for the degree of master of education (early years). Mossey University-New Zealand.

117. Silvia Blanch, David Duran, Vanessa Valdebenito \& Marta Flore (2012). The effects and characteristics of family involvement on a peer tutoring programme to improve the reading comprehension competence. http://link.springer.com/article/10.1007/s10212-012-0104-y. 
118. Silvia Gelabert, David Gisbert, Allen Thurston \& Keith Topping (2002). International on line peer tutoring to promote. Modern language development in primary school. Journal computers \& Education. No. 2, Vol. 53, Sep., p.p. 462-472.

119. Susan Middlestadt (2001). Turning minds on and faucets off :water conservation education in Jordanian schools. The journal of environmental education, Vol. 32, issue 2.

120. Willard R. Daggett, Gerald A. Pedinotti(2011). Cross-Age Peer Teaching An Effective and Efficient Model for Supporting Success in theClassroom. International Center for Leadership in Education

121. Yashvinder Kapil1 \& J. Sujatha Malini2, Ph. D. (2018). PEER TUTORING AN INSTRUCTIONAL STRATEGY: A SYSTEMATIC APPROACH. Scholarly Research Journal for Humanity Science \& English Language. PEER REVIEWED JOURNAL, APR-MAY 2018, VOL- 6/27.

122. Yusuf Abdulrahim, Hamdallat T. Yusuf, Adesegun O. Odutayo (2017). Effect of Peer Tutoring on Students' Academic Performance in Economics in Ilorin South, Nigeria. Journal of Peer Learning. Volume 10. Available at: http://ro.uow.edu.au/ajpl/vol10/iss1/7. 